\title{
Hydraulic and Thermal Response to Intermittent Pumping in Unconfined Alluvial Aquifers along a Regulated Stream
}

\author{
Madan Maharjan
}

Follow this and additional works at: https://researchrepository.wvu.edu/etd

\section{Recommended Citation}

Maharjan, Madan, "Hydraulic and Thermal Response to Intermittent Pumping in Unconfined Alluvial Aquifers along a Regulated Stream" (2017). Graduate Theses, Dissertations, and Problem Reports. 6141. https://researchrepository.wvu.edu/etd/6141

This Dissertation is protected by copyright and/or related rights. It has been brought to you by the The Research Repository @ WVU with permission from the rights-holder(s). You are free to use this Dissertation in any way that is permitted by the copyright and related rights legislation that applies to your use. For other uses you must obtain permission from the rights-holder(s) directly, unless additional rights are indicated by a Creative Commons license in the record and/ or on the work itself. This Dissertation has been accepted for inclusion in WVU Graduate Theses, Dissertations, and Problem Reports collection by an authorized administrator of The Research Repository @ WVU.

For more information, please contact researchrepository@mail.wvu.edu. 


\title{
Hydraulic and Thermal Response to Intermittent Pumping in Unconfined
}

\section{Alluvial Aquifers along a Regulated Stream}

\author{
Madan Maharjan \\ Dissertation submitted \\ to the Eberly College of Arts and Sciences \\ at West Virginia University \\ in partial fulfillment of the requirements for the degree of \\ Doctor of Philosophy in \\ Hydrogeology \\ Joe Donovan, Ph. D., Chair \\ Steve Kite, Ph. D. \\ Shikha Sharma, Ph. D. \\ Nicolas Zègre, $\mathrm{Ph}$. D. \\ Frank Borsuk, Ph. D. \\ Department of Geology and Geography \\ Morgantown, West Virginia \\ 2017
}

Keywords: Groundwater-surface water interaction, pumping induced temperature shifts, unconfined alluvial aquifer, intermittent pumping, and regulated stream

Copyright 2017 Madan Maharjan 


\title{
ABSTRACT \\ Hydraulic and Thermal Response to Intermittent Pumping in Unconfined
}

\author{
Alluvial Aquifers along a Regulated Stream
}

\author{
Madan Maharjan
}

Groundwater response to stream stage fluctuations was studied using a year-long time series of stream stage and well heads in Glen Dale and New Martinsville, WV. Stream stage fluctuations exerted primary control over groundwater levels, especially during high flows. The location and operation of river pools created by dams alter groundwater flow paths and velocities. Aquifers are more prone to surface water infiltration in the upper reaches of pools than in lower reaches. Aquifer diffusivity is heterogeneous within and between the two sites.

Temperature fluctuations were observed for 2.5 years in 14 wells in three alluvial aquifers. Temperature signals have 2 components corresponding to pump-on and pump-off periods. Both components vary seasonality at different magnitudes. While pump-off temperatures fluctuated up to $3.8^{\circ} \mathrm{C}$ seasonally, short-term temperature shifts induced by turning the pump on were 0.2 to $2.5^{\circ} \mathrm{C}$. Pumping-induced temperature shifts were highest in magnitude in summer and winter. Groundwater temperature lagged behind that of surface water by approximately six months. Pumping induced and seasonal temperature shifts were spatially and temporally complex but indicate stream exfiltration is a major driver for a number of these wells.

Numerical simulation of aquifer response to pumping show different conditions before and after well-field development. During pre-development, the stream was losing at high flow and gaining at low flow. During post-development, however, the stream was losing at high flow and spatially variable at low flow. While bank storage gained only during high stage, stream exfiltration occurred year-round. Pumping induced stream exfiltration by creating an extensive cone of depression beneath the stream in both upstream and downstream directions.

Spatially and temporally variable groundwater-surface water interaction next to a regulated stream were studied using analytical and numerical models, based on field observations. Seasonality plays an important role in these interactions, but human activity may also alter its intensity. 
This dissertation is dedicated to the memories of

My Beloved Grandfather

HIRA LAL MAHARJAN

(1935-2017) 


\section{Acknowledgements}

My sincere thanks to mentor and advisor Dr. Joe Donovan for advice, inspiration, and resources; Dr. Shikha Sharma for analyzing water isotope samples in her lab and assuring quality results; and Dr. J. Steven Kite for loan of a survey tripod; and to all my committee members for constructive feedback, critical reviews, and improvement of the dissertation.

I appreciate Bob Smith and Brad Hess (WV Bureau for Public Health) establishing points of contact with PWS managers, including David Benson (New Martinsville), Gary Williams (McMechen) and Sean Orlofske and Dave Hall (Glen Dale); these gentlemen cooperated in collecting water level data and water samples. I acknowledge financial support from the WV Bureau of Public Health, the Bob and Beverly Shumaker Fund, the WVU Doctoral Research Grant, and the Eberly College Doctoral Student Travel Grant programs.

My appreciation goes to Ajaya Sankara Warrier, Stable Isotope Lab of the Department of Geology and Geography at West Virginia University, for his promptness in analyzing water samples and to Gabriela Perhinschi, National Research Center for Coal and Energy Analytical Laboratory, West Virginia University, for analyzing and reanalyzing inorganic water chemistry. I also thank colleagues Mitchell McAdoo and Vikash Agrawal for assistance in the field and lab. My thanks to my friend and brother, Dr. Tej Gautam, for reviewing Chapter 4 and to another friend, Bhusan Aryal, for proofreading.

My heartfelt thanks to my parents and grandparents, especially to my mother taking care of my daughter for nearly two years in the US; to my spouse, Nila Raut Maharjan, for her support and motivation throughout the journey; and to daughter, Nishma Maharjan, for her refreshing smile. Your support and encouragement was worth more than I can express. 


\section{Table of Contents}

List of Tables............................................................................ vii

List of Figures........................................................................ viii

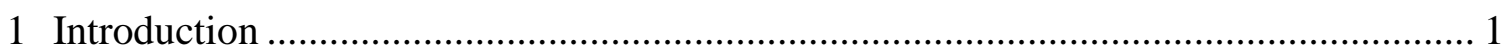

1.1 Groundwater-surface water interaction ....................................................... 1

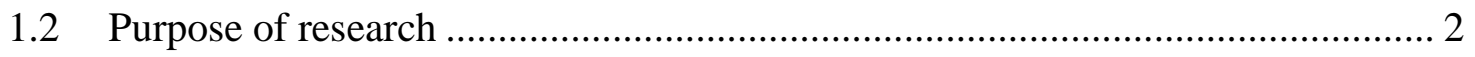

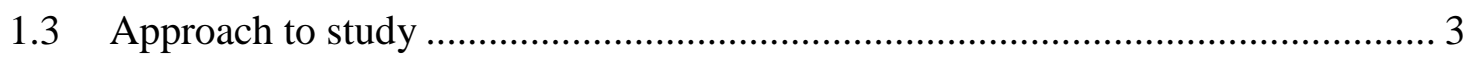

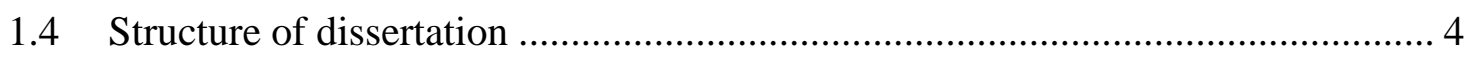

2 Groundwater response to multiple stream stage fluctuations in shallow unconfined alluvial aquifers along a regulated stream .............................................................. 5

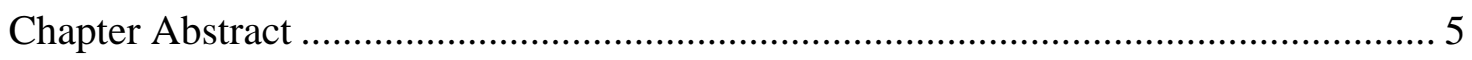

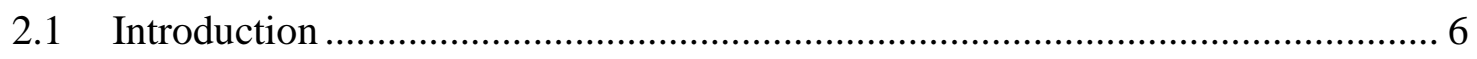

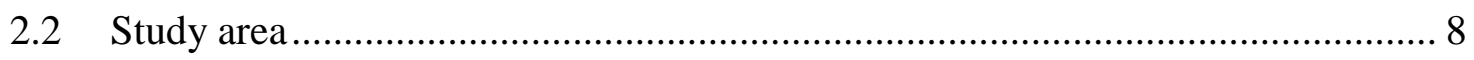

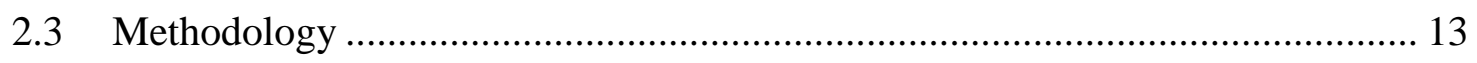

2.3.1 Analysis of aquifer head and stream stage ……......................................... 13

2.3.2 Analytical model of flood-wave response .................................................... 13

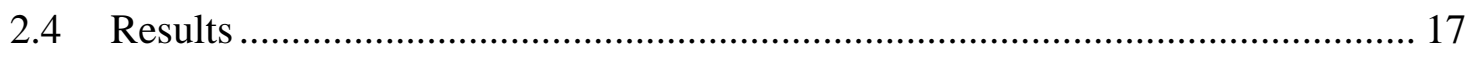

2.4.1 Aquifer and stream hydrographs ……………………………………..... 17

2.4.2 Simulated aquifer heads driven by stream fluctuations ................................ 21

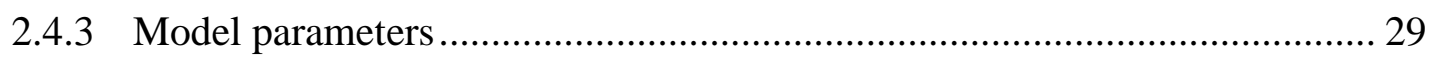

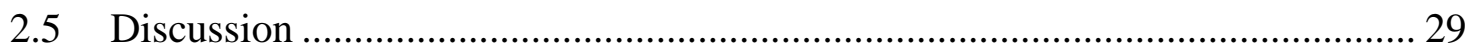

2.5.1 Spatial differences in groundwater-stream interaction................................. 29

2.5.2 Temporal differences in groundwater-stream interaction .............................. 31

2.5.3 Effects of dam operation ………………………….................................. 32

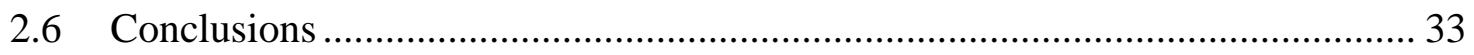


3 Temperature variations in intermittently-pumped wells within unconfined alluvial

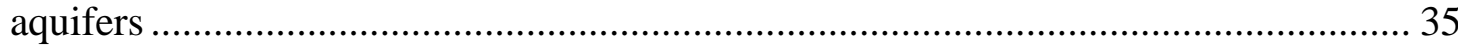

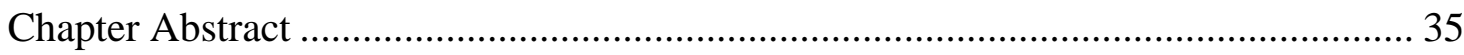

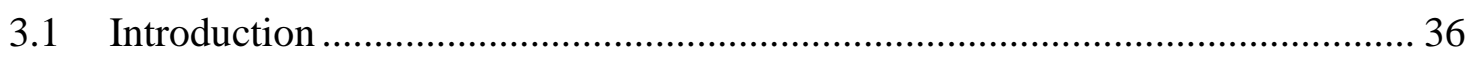

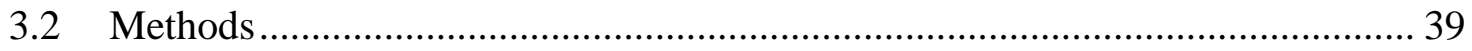

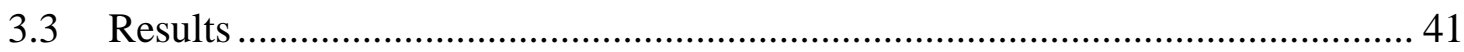

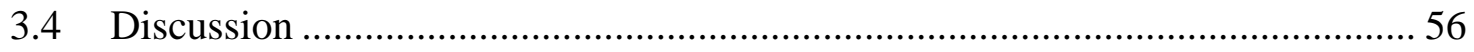

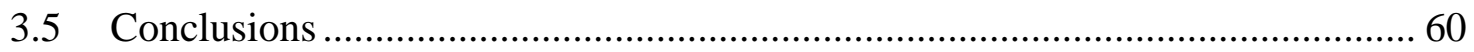

4 Numerical modeling of alluvial aquifer response to pumping under fluctuating stream

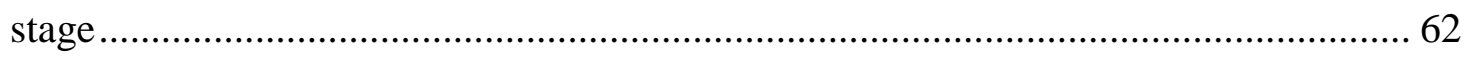

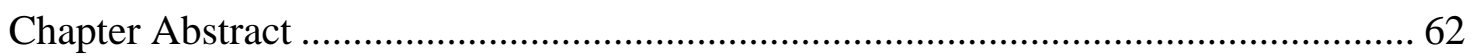

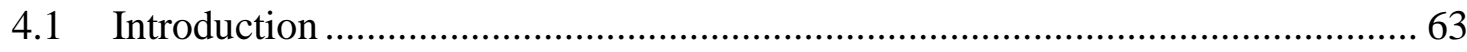

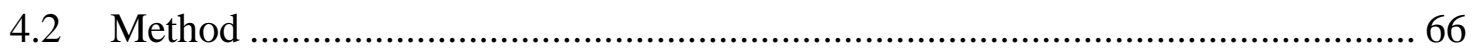

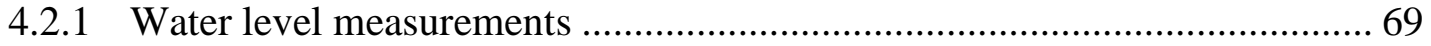

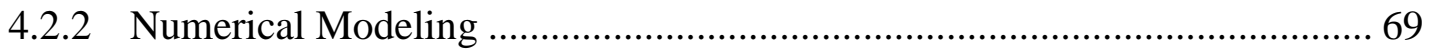

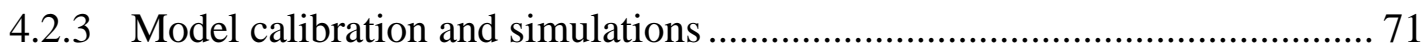

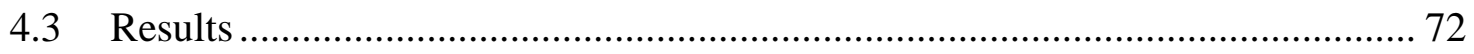

4.4 Discussion and conclusion ................................................................. 78

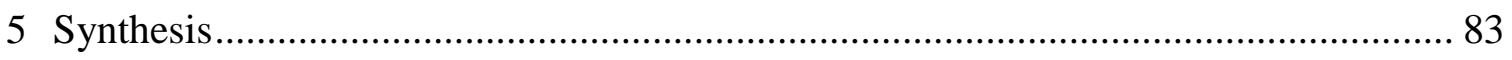

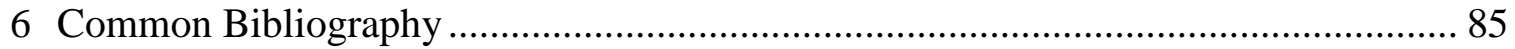




\section{List of Tables}

Table 2.1 Characteristics of wells used in the study area. 12

Table 2.2 Comparison between single-peak (May 2014) stage-ratio and multiple-peak transient modeled diffusivity for Glen Dale and New Martinsville aquifers.

Table 3.1 Well characteristics, lag times $(\tau)$, and temperature shifts observed in wells at the 3 PWSs

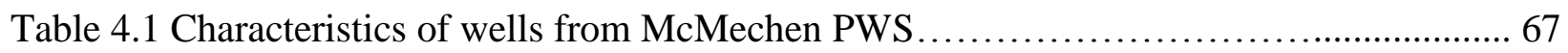

Table 4.2 Parameter estimation for the calibrated model ........................................................ 74

Table 4.3 Comparison of calibrated aquifer parameters with those from previous hydrogeological studies along the Ohio River.

Table 4.4 Induced infiltration, bank storage, and baseflow values derived from MODFLOW mass balance. 


\section{List of Figures}

Figure 2.1 Study area: Glen Dale and New Martinsville well fields along the Ohio River. 9

Figure 2.2 Cross section of the Ohio River pools between Pike Island Lock and Dam and

Hannibal Locks and Dam.

Figure 2.3 Conceptual model of surface water exfiltration to an aquifer during stage rise from A

to $\mathrm{B}$ 15

Figure 2.4 Daily maximum water levels at (a) Wheeling (WG), (b) pool upstream (UG), and (c) pool downstream (LG) of Hannibal dam from October 2013 to February 2015. 18

Figure 2.5 Groundwater and Ohio River stage measured at Glen Dale from February 2014 to February 2015.

Figure 2.6 Groundwater and Ohio River stage time series from February 2014 to February 2015

at New Martinsville (a) pool upstream and (b) pool downstream of Hannibal Lock and Dam

Figure 2.7 Lagged-cross correlation of aquifer response to river stage fluctuations during high-

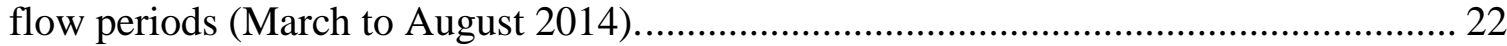

Figure 2.8 Modeled versus observed daily maximum water level at wells (a) G3 and (b) G1... 23

Figure 2.9 Stream stage, induced infiltration rate, and net change in storage based on well G1 at

Glen Dale. 24

Figure 2.10 Modeled versus observed water levels at wells N1, N3, and N4 at New Martinsville.

Figure 2.11 Estimated induced infiltration rate and unit-width cumulative bank storage due to river fluctuation at the lower reach of the Hannibal pool near well N4.

Figure 2.12 Induced infiltration rate and net change in storage due to river fluctuation around well N3 in the upper reach of the Willow Island pool.

Figure 3.1 Site map of New Martinsville, Glen Dale, and McMechen PWS systems showing

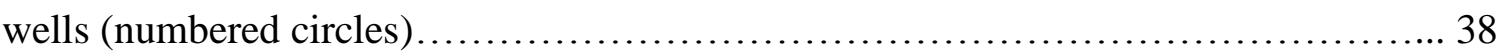

Figure 3.2 Generalized logger well logs from New Martinsville PWS showing water levels ..... 42 Figure 3.3 A conceptual geological cross-section of the Ohio River valley with (top) a pumping well and associated flow lines and (bottom) inferred heat transport mechanisms. 
Figure 3.4 Temperature variations (dark grey) superimposed on seasonal fluctuations in water level (light grey) for well M5 between May 2014 and August 2016............................ 45

Figure 3.5 Seasonal oscillations of river temperature (dashed line) and air temperature (solid

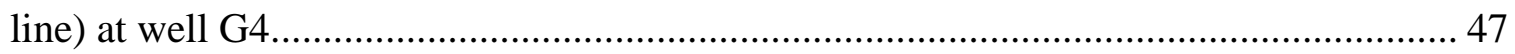

Figure 3.6 High-resolution PITS during (a) summer and (b) winter at well N4. ..................... 48

Figure 3.7 Stream temperature (top), water-level (grey), and temperature (black) fluctuations from February 2014 to August 2016 at wells N4 and N5, New Martinsville PWS. ....... 50

Figure 3.8 STS and $\tau$ for non-pumping wells at Glen Dale PWS ..................................... 52 Figure 3.9 PITS, STS, and $\tau$ of pumping wells at increasing distance from the river, top (river) to

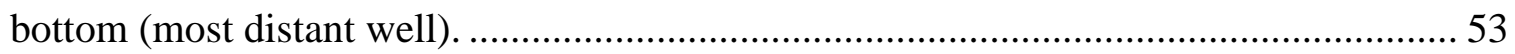

Figure 3.10 PITS, STS, and $\tau$ of pumping wells at increasing depth below the surface............ 55

Figure 3.11 Lag time and STS vs sensor depth for pumping and non-pumping wells............... 57

Figure 4.1 Site map of McMechen PWS showing pumping wells (numbered circles)......... 65

Figure 4.2 A representative cross-section of the Ohio River valley showing aquifer geometry, lithology, and water levels in both the river and aquifer. .......................................... 68

Figure 4.3 MODFLOW model showing well locations, bedrock, aquifer boundary, and no flow cells. 70

Figure 4.4 Observed and simulated water level in the wells M1 and M5 in response to a 10-day stream hydrograph observed in December 2014 (Top).

Figure 4.5 Groundwater flow paths (arrow head directions) during low and high stream stages at

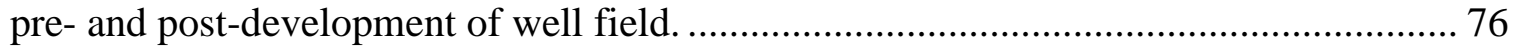

Figure 4.6 The shape and extent of the cone of depression in response to changes in aquifer

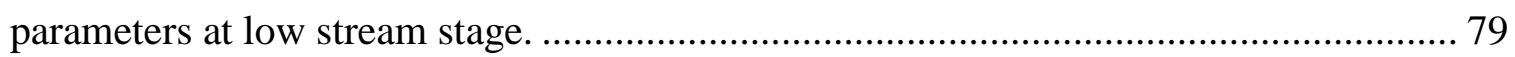

Figure 4.7 The shape and extent of the cone of depression in response to changes in aquifer parameters at high stream stage. 


\section{Introduction}

\subsection{Groundwater-surface water interaction}

Groundwater-surface water interaction is common in aquifers adjacent to surface-water sources (i.e., streams, lakes, wetlands) and is caused by difference in hydraulic head along the boundary between them (Winter, 1995). The phenomenon is influenced by hydrogeological, climatic, morphological, and human factors (Winter et al., 1998; Sophocleous, 2002). The phenomenon has implications for regulatory agencies and public water supply (PWS) systems as defined in the Safe Drinking Water Act (USEPA, 1997).

Within stream-aquifer systems, four basic variants occur i) a stream receives groundwater (gaining stream), ii) a stream loses water to aquifer (losing stream), iii) no water exchange (neutral stream), and (iv) stream gains water in some reaches and loses from others (gaining/losing stream). Gaining and losing streams are both driven by difference in hydraulic head between the aquifer and the stream (Boutt and Fleming, 2009). A disconnected stream is a special type of losing stream in which the water table lies below the streambed. Groundwatersurface water interaction makes possible not only baseflow to streams but also the potential for reversal of flow path, i.e. induced infiltration (Desimone and Barlow, 1998).

Precipitation and snow melt are major sources of both groundwater recharge and surface water flow (Winter, 1995). Abrupt changes in stream stage can induce changes in aquifer head, commonly with decreased amplitude at increasing distance from the stream (Ferris, 1952; Rosenshein, 1988). Stream stage generally fluctuates more rapidly than the rate at which

groundwater levels can respond (Kelly, 2001). Flood events of streams generate pressure waves, 
which can propagate across an aquifer 2 to 3 orders of magnitude faster than typical groundwater velocities (Jung et al., 2004; Lewandowski et al., 2009; Welch et al., 2013; Cloutier et al., 2014).

Bank storage is temporarily-stored groundwater in alluvial aquifers emplaced by streamstage fluctuations (Squillace, 1996). It does not always recede as rapidly as stream stage does thus causing a hysteresis between aquifer head and bank storage (Herrmann et al., 2013). Bank storage depends upon aquifer and streambed properties, the amplitude and the duration of flood wave, and, in some cases, pumping duration and rate (Serfes, 1991; Kelly, 2001; Lewandowski et al. 2009). Bank storage attenuates a flood wave and can contribute substantial discharge back to a stream during baseflow periods (Cooper and Rorabaugh, 1963).

Human activities can alter these interactions. Pumping can reduce or even eliminate baseflow to a gaining stream (Chen and Chen, 2003). Prolonged pumping can reverse the hydraulic gradient and induce stream exfiltration to the aquifer (Barlow and Leake, 2012). Flow reversal may also be driven by river stage rise due to stream regulation (Lewandowski et al., 2009, Maharjan and Donovan, 2016).

\subsection{Purpose of research}

The purpose of this study is to investigate groundwater-surface water interactions due to human and seasonal causes in unconfined alluvial aquifers adjacent to a regulated stream, whose stage is maintained by dams. This study will employ a one-dimensional analytical model of aquifer heads, field observations of surface and groundwater temperatures, and a numerical model of water levels in the aquifer and stream. Specific objectives include:

i) Spatial and temporal variations of aquifer water level and temperature in response to stream-stage fluctuations and pumping; 
ii) Identification of source water to pumping wells;

iii) Simulation of aquifer heads during pre- and post-development; and

iv) Delineation of the shape and extent of the pumping cone of depression during high and low flow periods.

The study areas (Town of McMechen, Glen Dale, and New Martinsville) are located in the Northern Panhandle of West Virginia along the Ohio River Valley. Groundwater in McMechen, Glen Dale, and New Martinsville is intermittently pumped at approximately 6000, 2000, and $8000 \mathrm{~m}^{3} /$ day, respectively, using 11 wells completed near the base of the gravel aquifer. The Ohio River Valley was filled with sand, gravel, silt, and clay and capped by Quaternary terraces ( Carlston, 1962; Simard, 1989; Rogers, 1990). Narrow bands of Quaternary alluvium occur as floodplain deposits along the major tributaries. The river stage is regulated at constant pool levels throughout the year with adjacent pools separated about $6.4 \mathrm{~m}$ by lock and dams. River stage fluctuates minimally just upstream of dams and much higher downstream of them.

\subsection{Approach to study}

The key dataset employed were high-frequency water level and temperature measurements from both the stream and wells in the aquifer. Because not all well-head elevations were known, missing elevations were determined by a high-precision level survey. These data were then examined for evidence of coupling between stream stage and aquifer head. Similarly, the high-frequency temperature observations of groundwater and surface water were analyzed for short-term (pumping) and long-term (seasonal) scale interactions between the two. Aquifer response to pumping under fluctuating stream stage conditions was then simulated using a numerical model, as a hypothesis testing tool. 


\subsection{Structure of dissertation}

This dissertation is presented as a series of stand-alone thematic papers (Chapters 2 to 4 ) and an overall summary (Chapter 5). Although each thematic chapter includes its own abstract, introduction, and conclusion, this dissertation comprises of separate integrated abstract, introductory, and conclusion chapters. However, all the citations are compiled at the end of this dissertation under a common bibliography section.

The three chapters deal with, in order of presentation:

I. Alluvial aquifer response to stream-stage fluctuations in an annual cycle using water levels from the Ohio River and two aquifers at Glen Dale and New Martinsville;

II. Groundwater temperature response to intermittent pumping using high-frequency temperature dataset from 14 wells in three PWS and the Ohio River; and

III. Alluvial aquifer response to pumping under stream-stage fluctuations using a numerical model of McMechen aquifer.

Since each chapter stands individually in the form of manuscripts for submission to a journal, substantial redundancy is undergone, especially in introductory material. However, each chapter focuses on different datasets to elucidate hydrogeological processes. Chapter 2 has already been published and is presented here without significant changes (Maharjan and Donovan, 2016). 


\title{
2 Groundwater response to multiple stream stage fluctuations in
}

\section{shallow unconfined alluvial aquifers along a regulated stream}

\begin{abstract}
Chapter Abstract
Groundwater response to stream stage fluctuations was studied in two unconfined alluvial aquifers using a year-long time series of stream stages from two pools along a regulated stream. The purpose was to analyze spatial and temporal variations in groundwater-surface water interaction and to estimate induced infiltration rate and cumulative bank storage during an annual cycle of stream stage fluctuation. A convolution-integral method was used to simulate aquifer head at different distances from the stream caused by stream stage fluctuations and to estimate fluxes across the stream-aquifer boundary. Aquifer diffusivities were estimated by wigglematching time and amplitude of modeled response to multiple observed storm events. The peak lag time between observed stream and aquifer stage peaks ranged between 14 and 95 hour. Transient modeled diffusivity ranged from 1,000 to $7,500 \mathrm{~m}^{2} /$ day and deviated from the measured and calculated single-peak stage-ratio diffusivity by $14-82 \%$. Stream stage fluctuation displayed more primary control over groundwater levels than recharge, especially during highflow periods. Dam operations locally altered groundwater flow paths and velocity. The aquifer is more prone to surface-water control in upper reaches of the pools where stream stage fluctuations are more pronounced than in the lower reaches.
\end{abstract}




\subsection{Introduction}

Exchange between groundwater and streams occurs according to the hydraulic gradient at their interface (Boutt and Fleming, 2009). This exchange influences not only baseflow amounts but also the potential for periodic reversal of flow path, i.e. induced infiltration (Desimone and Barlow, 1998). Stream stage commonly fluctuates more rapidly than the rate at which groundwater levels at distance from the stream can respond (Kelly, 2001). Head variations in unconfined aquifers are influenced by pumping, stream stage fluctuations, and aquifer and streambed properties (Todd, 1980; Rosenshein, 1988; Welch et al., 2013). Time series of alluvial heads and adjacent stream stage often show strong correlation (Cloutier et al., 2014). A stream may be ascertained to be gaining when the groundwater stage is higher than that of the stream. Stream stage fluctuations lag groundwater fluctuations during gaining periods and the opposite for losing periods. Abrupt changes in stream stage induce changes in aquifer head but with decreased amplitude and increased peak lag at increasing distance from the stream (Ferris, 1952; Rosenshein, 1988).

Aquifer heads can fluctuate due to lateral (stream exfiltration and regional potentiometric gradient), vertical (recharge, evapotranspiration, and/or leakage), and/or pumping stresses (Ferris, 1952; Hall and Moench, 1972; Chen, 2003; Rötting et al., 2006). Stream stage fluctuations can exert greater control over aquifer heads than well and aquifer boundary conditions in highly-transmissive aquifers (Spane and Mackley, 2011; Cloutier et al., 2014). Stream-induced flood waves can propagate across an aquifer 2 to 3 orders of magnitude faster than typical groundwater velocities (Jung et al., 2004; Lewandowski et al., 2009; Welch et al., 2013; Cloutier et al., 2014). Flood waves induce surface water into adjacent alluvial aquifers, which later returns to the stream as its stage is lowered; this is commonly referred to as bank 
storage (Squillace, 1996). Bank storage does not always recede as rapidly as stream stage drops, producing a hysteresis between aquifer head and bank storage (Herrmann et al., 2013). Bank storage depends upon aquifer and streambed properties, the amplitude and duration of flood wave, pumping duration and rate, and the distance of well from a stream (Serfes, 1991; Kelly, 2001; Lewandowski et al., 2009).

Jacob (1950) first examined the effects of periodic fluctuations in stream stage on an aquifer and found the rate of aquifer response related to its hydraulic diffusivity. Such response has been modeled using various one-dimensional analytical solutions which estimate homogeneous aquifer properties based on matching water levels (Ferris, 1952; Rowe, 1960; Pinder et al., 1969; Grubb and Zehner, 1973; McFadden, 1983; Reynolds, 1987). Such solutions have also been used to estimate bank storage and induced infiltration rate (Cooper and Rorabaugh, 1963; Hall and Moench, 1972; Reynolds, 1987; Barlow et al., 2000; Chen and Chen, 2003, Lewandowski et al., 2009; Welch et al., 2013; Cloutier et al., 2014).

Much of this research has used stream hydrographs of a single high-flow event as a forcing condition. Cooper and Rorabaugh (1963) derived solutions using a hypothetical stream boundary condition and observed that bank storage declined to $14 \%$ of its maximum after $10 \mathrm{~d}(\mathrm{~d}$ $=$ flood duration, in days). In a similar study, Chen and Chen (2003) modeled flood-induced residual bank storage and showed it declined to between 10 and $27 \%$ of its maximum after $6 \mathrm{~d}$. However, in reality, multiple flood events commonly occur over shorter timeframes than the times in these investigations. Furthermore, a key practical result of such models is how much bank storage can not only be retained but also used over a series of flood events. Therefore, a more effective application of such analytical results may require transient application over longer timeframes than for a single flood event. To the authors' knowledge, no one has studied the 
effects of such long-term stream stage fluctuations on bank storage and infiltration rate. This would ideally employ simultaneous measurement of stream stage and aquifer heads at different distances from the stream, in a hydrologic setting where stream fluctuations are frequent and large. Stream stage and aquifer head would act as the source function and calibration dataset, respectively, for any model employed. Ideally, a period covering both high and low flow would be useful to show seasonal differences in response.

The purpose of this study, therefore, is to investigate (a) differences in alluvial aquifer behavior along different reaches of a long stream; and (b) differences in aquifer response to stream fluctuations between low and high flow periods. This will employ a year-long highfrequency dataset for aquifer head at different distances from a stream undergoing frequent stream stage fluctuations. Using these data, a model will be developed and calibrated against these heads to estimate a locally-homogeneous aquifer diffusivity across the full study period. Using the calibrated model, bank storage and induced infiltration rates will be estimated for the aquifer over the study period. Single-peak stage-ratio diffusivity (measured and calculated) for each well will be compared with the multiple-peak transient modeled diffusivity to determine the robustness of the model assumptions.

\subsection{Study area}

The study area is located in the Ohio River Valley of West Virginia with observation wells located in two public water supply (PWS) systems: Glen Dale and New Martinsville (Figure 2.1). Dominant local bedrock lithologies in West Virginia are shale, sandstone, limestone, clay, and coal of Permian and Pennsylvanian age. The Pleistocene-Holocene aged Ohio River incised those flat-lying, low-conductivity rocks to form the modern valley (Prellwitz, 


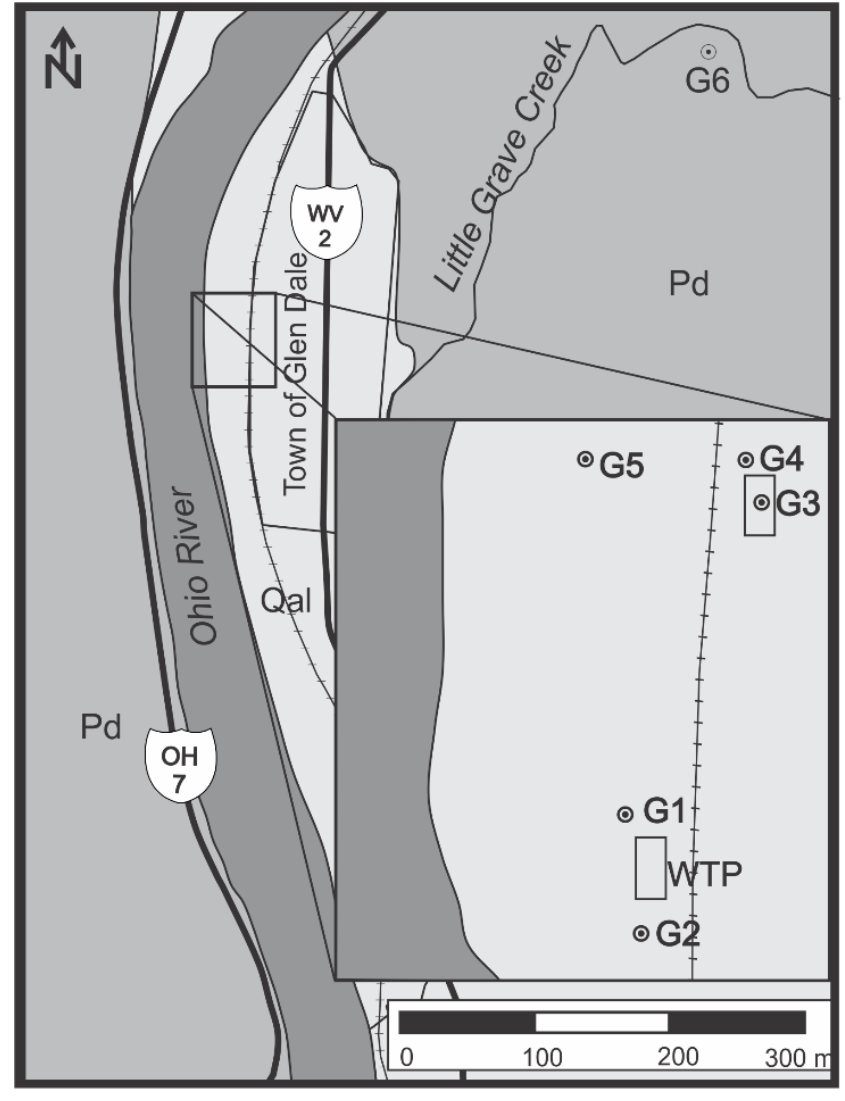

(a) Glen Dale PWS

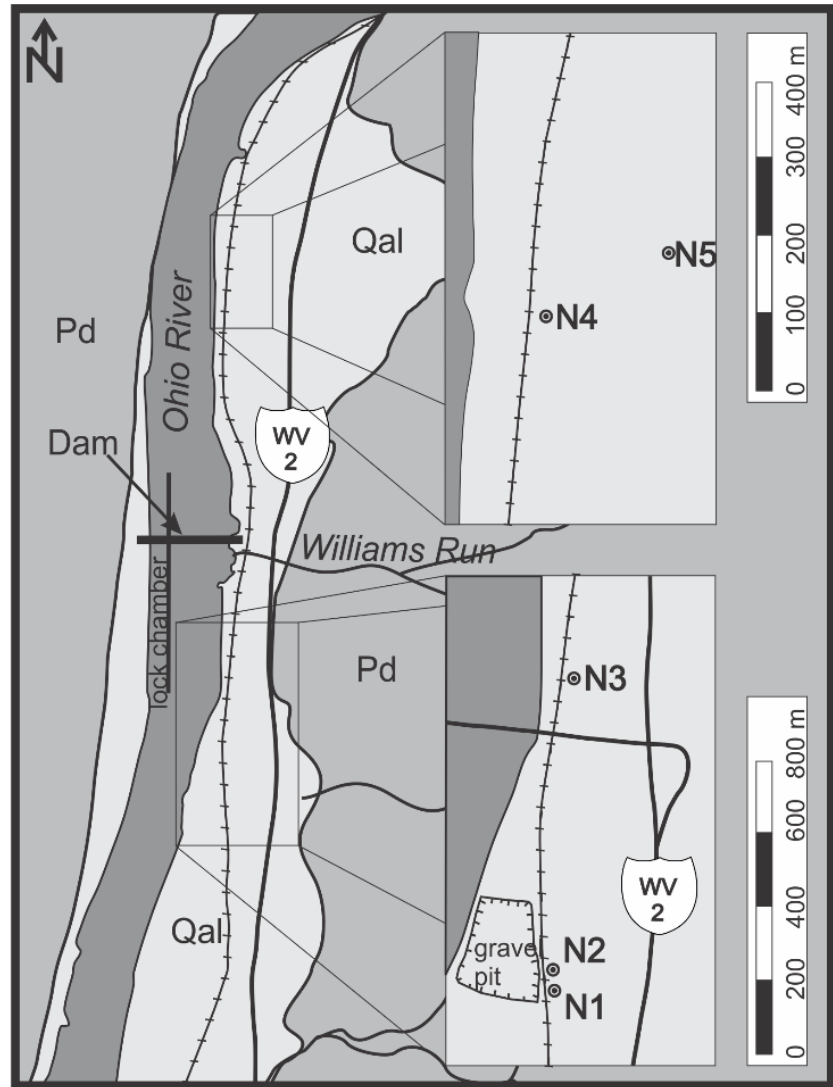

(b) New Martinsville PWS

Figure 2.1 Study area: Glen Dale and New Martinsville well fields along the Ohio River. WTP is water treatment plant. 
2004) and filled its valley with sand and gravel, silt, and clay underlying Quaternary terraces (Carlston, 1962; Simard, 1989; Rogers, 1990). Narrow bands of Quaternary alluvium also occur as either terrace or floodplain deposits along the major tributaries. The river is regulated at a constant pool level throughout a year just upstream of a dam. The term "pool" in this context refers to a reach of a river between two consecutive dams. A pool is at close to uniform elevation, although stage declines downstream, especially along the upper pool reach. Pool levels in many locations fluctuate rapidly during and after torrential storms and spring snowmelt events. For example, Ohio River stage near Wheeling rose $11.27 \mathrm{~m}$ in 2011.

Groundwater in Glen Dale and New Martinsville is pumped at approximately 2,000 and $8,000 \mathrm{~m}^{3} /$ day, respectively, from the unconfined alluvial aquifer using seven wells completed near the base of the gravel aquifer. Table 2.1 summarizes pumping and observation wells within the study area. The Glen Dale well field has three observation wells and two production wells, pumped intermittently one well at a time with weekly rotation. The New Martinsville well field has five pumping wells pumped intermittently that are in use with two wells N4 and N5 alternating operation. At both sites, observed well heads allow examination of hydraulic head fluctuations both close to and at a distance from the river.

Locks with accompanying dams are major facilities for navigation along the Ohio River. Hannibal Locks and Dam lies across the Ohio River from the town of New Martinsville. Gated dams maintain a relatively constant river stage $(190 \mathrm{~m})$ upstream of the dam and create a head difference of $6.4 \mathrm{~m}$ between the upstream and downstream pools (Figure 2.2). Seven of the 10 observation wells used lie adjacent to the 68 -km-long Hannibal pool. The New Martinsville system has three wells downstream and two wells upstream of the dam. Wells N1, N2, and N3 are approximately $1,600,1,500$, and $750 \mathrm{~m}$ downstream and $\mathrm{N} 4$ and $\mathrm{N} 5$ are approximately 1,500 


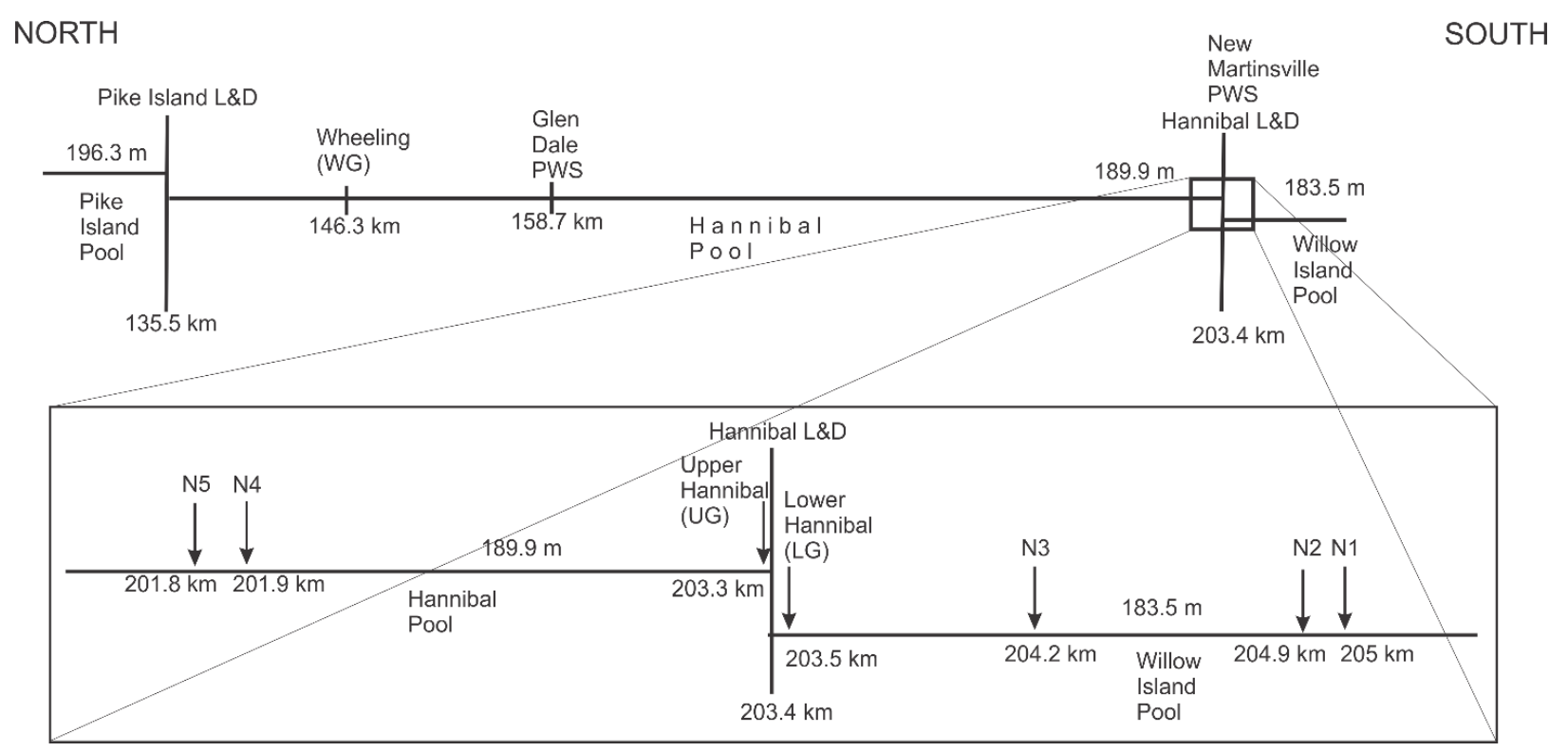

Figure 2.2 Cross section of the Ohio River pools between Pike Island Lock and Dam and Hannibal Locks and Dam. The metrics below the line represent the Ohio River mileage from its origin and above the line represent pool elevation (MSL) (USACE, 2003). 
Table 2.1 Characteristics of wells used in the study area.

\begin{tabular}{|c|c|c|c|c|c|c|c|c|c|c|}
\hline \begin{tabular}{l|}
$\mathrm{P}$ \\
$\mathrm{W}$ \\
$\mathrm{S}$
\end{tabular} & Well & $\begin{array}{c}\text { Pump } \\
\text { Rate } \\
\text { (m²/day) }\end{array}$ & $\begin{array}{l}\text { Distance } \\
\text { from } \\
\text { river }(\mathrm{m})\end{array}$ & $\begin{array}{c}\text { Screen } \\
\text { Length } \\
(\mathrm{m})\end{array}$ & $\begin{array}{c}\text { Elevation } \\
\text { (m) }\end{array}$ & $\begin{array}{l}\text { Well } \\
\text { Depth } \\
(\mathrm{m})\end{array}$ & $\begin{array}{c}\text { Water } \\
\text { Table } \\
(\mathrm{m})\end{array}$ & $\begin{array}{c}\text { Casing } \\
\text { Height } \\
\text { (m) }\end{array}$ & $\begin{array}{c}\text { Sensor } \\
\text { Elevation } \\
\text { MSL (m) }\end{array}$ & $\begin{array}{c}\text { Aquifer } \\
\text { Width } \\
\text { (m) }\end{array}$ \\
\hline \multirow{5}{*}{$\begin{array}{l}\frac{0}{\pi} \\
\overline{0} \\
\frac{\tilde{v}}{0}\end{array}$} & G1 & 2,071 & 140 & 7.6 & 199.6 & 24.4 & 190.4 & 0.2 & 184.6 & 1,000 \\
\hline & G2 & 2,071 & 146 & 7.6 & 199 & 24.4 & 189.9 & 0.6 & 184.4 & 1,000 \\
\hline & G3 & - & 250 & - & 204.5 & 24.1 & 193.5 & 0.2 & 189.4 & 1,000 \\
\hline & G4 & - & 230 & - & 203.9 & 25.2 & 191 & 0 & 184.1 & 1,000 \\
\hline & G5 & - & 110 & - & 197.2 & 9.5 & 190.5 & 0 & 188.7 & 1,000 \\
\hline \multirow{5}{*}{ 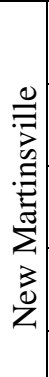 } & N1 & 1,908 & 270 & 3.7 & 192 & 17.7 & 181.1 & 1.8 & 180.3 & 950 \\
\hline & N2 & 1,635 & 250 & 3.7 & 192.6 & 18 & 180.9 & 1.8 & 179.8 & 950 \\
\hline & N3 & 2,180 & 90 & 4.6 & 196 & 22.7 & 182.9 & 0.5 & 178.5 & 300 \\
\hline & N4 & 2,589 & 105 & 6.1 & 195.4 & 22.9 & 189.2 & 0.3 & 186.8 & 1,400 \\
\hline & N5 & 2,180 & 270 & 2.7 & 197.5 & 20.4 & 189.1 & 0.3 & 183.8 & 1,400 \\
\hline
\end{tabular}

Wells G2, G4, and G5 had sealed loggers, while well G4 had an additional barometric logger. 
and 1,600 m upstream from the dam respectively. This setting allows examination of the effect of dam operations on groundwater flow.

\subsection{Methodology}

\subsubsection{Analysis of aquifer head and stream stage}

Groundwater response to stream stage fluctuations was measured at 10 wells from February 2014 to February 2015. 30-minute-interval river stages were compiled for the three U.S. Geological Survey gaging stations (Wheeling, Upper Hannibal, and Lower Hannibal) across two river pools (Hannibal and Willow Island) from October 2013 to February 2015. Pressure transducers coupled to data loggers (vented Global Water® WL-16 and sealed Onset巴 U020) were installed in pumping wells below their pumping water levels to collect fluid pressures at 1minute intervals. These transducers have pressure accuracy of $\pm 0.1 \%$ and $\pm 0.05 \%$ of full scale, respectively. The loggers were downloaded monthly and converted to heads above mean sea level using standard techniques (Weight and Sonderegger, 2001). Water column height above the sensor was measured periodically with an electric tape $( \pm 5 \mathrm{~mm})$ to verify transducer readings.

For the intermittently-pumping wells, daily maximum heads were employed to eliminate the effects of pumping well losses. Later, hourly heads for those wells were interpolated using cubical spline function. Lagged cross-correlation was used to estimate peak lag time between stream and groundwater levels (Sheets et al., 2002).

\subsubsection{Analytical model of flood-wave response}

Figure 2.3 shows a conceptual model of surface-alluvial aquifer interaction after stream stage rises from low (A) to high (B), increasing bank storage by some volume (C). To simulate the conditions of Figure 2.3, a one-dimensional solution employing the Dupuit-Forchheimer 
assumption was developed to estimate head across a semi-infinite aquifer bounded by the stream on one side and a low-conductivity valley wall on the other.

$$
\frac{\partial^{2} \mathrm{~h}}{\partial \mathrm{x}^{2}}=\frac{1}{\mathrm{D}} \frac{\partial \mathrm{h}}{\partial \mathrm{t}}
$$

Boundary conditions are

$$
\begin{aligned}
& h(x, 0)=h_{0} \\
& \frac{\partial h}{\partial x}(L, t)=0 \\
& h(0, t)=f(t)
\end{aligned}
$$

where

$\mathrm{h}(\mathrm{x}, \mathrm{t})=$ aquifer stage at distance $\mathrm{x}$ from the stream at time $\mathrm{t}$

$\mathrm{D}=$ aquifer diffusivity

$\mathrm{h}_{0}=$ initial water level

$\mathrm{L}=$ aquifer width

$\mathrm{t}=$ time since the beginning of stream stage fluctuations

$\mathrm{f}(\mathrm{t})=$ time-varying stream stage

Per the Dupuit-Forcheimer assumption, Equation (1) applies to an unconfined aquifer in which water level fluctuations are very small in comparison to the saturated thickness and all flow is horizontal (Hantush, 1965). Induced aquifer head variations in response to $\mathrm{f}(\mathrm{t})$ were solved using the convolution integral by considering only surface water fluctuations, i.e. no groundwater withdrawal, recharge, lateral inflow, or evapotranspiration (Hall and Moench, 1972). Observed stream stage, only, was employed to drive aquifer head fluctuations. The solution is:

$$
h(x, t)=h_{0}+\int_{0}^{t} \frac{d f(t)}{d \tau} \operatorname{erfc}\left(\frac{x}{\sqrt{4 D(t-\tau)}}\right) d \tau
$$

In numerical evaluation of Equation (2), changes in stream stage within a uniform time step were held constant. Similar to Hall and Moench (1972), the solution calculated induced 


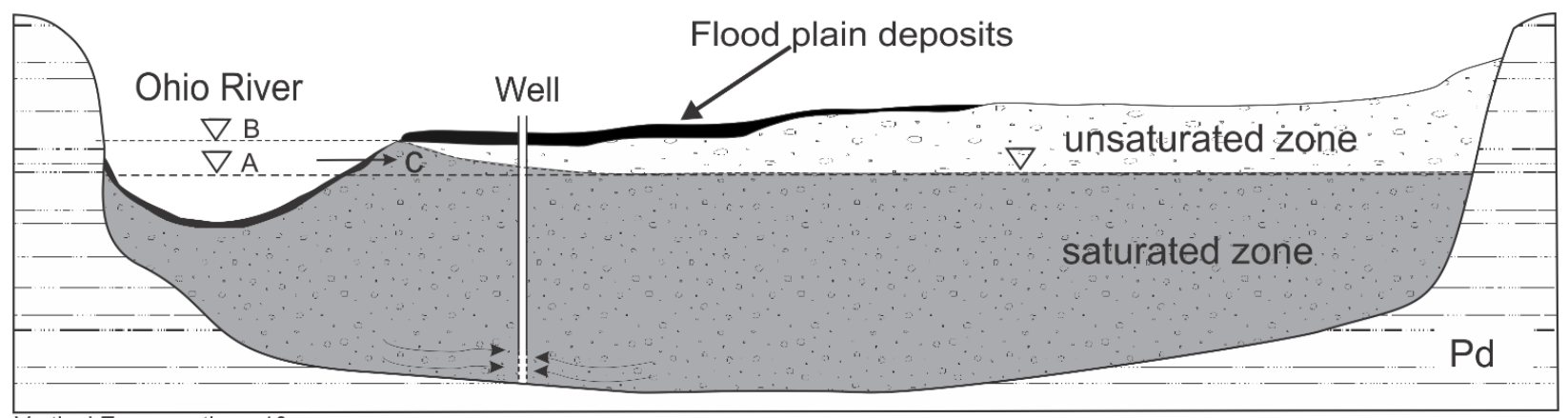

Vertical Exaggeration $=10 x$

Figure 2.3 Conceptual model of surface water exfiltration to an aquifer during stage rise from A to $B$. The aquifer thickness and width range in between $10-20 \mathrm{~m}$ and $300-1300 \mathrm{~m}$, respectively. The Ohio River is 400-500 $\mathrm{m}$ wide. 
infiltration rate and bank storage at each time step. The transmissivity of the aquifer was estimated from the modeled diffusivity using storage coefficient of 0.2 (assumed). The negative sign connotes aquifer outflow rate and volume, respectively.

$$
\begin{aligned}
& Q(t)=T \frac{\partial h(0, t)}{\partial x} \\
& v(t)=\int_{0}^{t} Q(t) d t
\end{aligned}
$$

where

$$
\begin{aligned}
& \mathrm{T}=\text { Transmissivity } \\
& \mathrm{Q}=\text { unit-width induced infiltration rate } \\
& \mathrm{v}=\text { unit-width bank storage }
\end{aligned}
$$

Model assumptions include: (i) homogeneous aquifer properties; (ii) all groundwater flow perpendicular to the river bank; (iii) no pumping from wells; and (iv) no recharge. Under these assumptions, stream stage fluctuations drive all aquifer response.

Simulation using Equation (2) at hourly time steps was started at the end of a recession period, October 2013, when the stream was at the lowest stage, i.e., near steady state (Reynolds, 1987). Aquifer head, induced infiltration rates, and bank storage were coded and simulated in MATLAB® for the period October 2013 to February 2015. The model estimated aquifer head for a year at a time, resetting the initial condition to the lowest stream-recession stage for each year. The model was calibrated by varying aquifer diffusivity to match simulated to observedaquifer heads based on congruence of multiple hydrograph peaks associated with flood waves (Pinder et al., 1969), yet not to exceed the observed aquifer heads. This resulting transient diffusivity was compared to single-peak (May 2014) stage-ratio diffusivity calculated using 
observed peak-height ratios of well to stream, analogous to Equation. (2), assuming the stream rise was instantaneous (Carslaw and Jaeger, 1959).

\subsection{Results}

\subsubsection{Aquifer and stream hydrographs}

Stream stage at the upper reaches of the two pools (Hannibal and Willow Island) showed fluctuations that were quite different from those of the lower reach of the Hannibal pool (Figure 2.4). In the upper reaches, high flows dominated from December to May and low flows thereafter until November. However, in the lower reach, low flow was indistinguishable from high flow and stream fluctuation was an order of magnitude or more lower than in the upper reaches. Stream stage at the upper reach of the Hannibal Pool rose up to $4 \mathrm{~m}$ above baseflow level. The peak flows occurred at the same time as there was a drop in regulated stage at the downstream limit of the pool (e.g., the dam). That is, there was poor correlation between hydrographs in different parts of the pools related to dam operations.

Hydraulic head in Glen Dale and New Martinsville wells at different distances from the Ohio River mimicked the stream hydrograph, especially during high flow (Figure 2.5 and 2.6). At low flow, fluctuations in aquifer and stream stage were infrequent and of low amplitude. Stream stage remained significantly higher than aquifer water level during high flow and viceversa during low flow at Glen Dale (Figure 2.5) and the upper reach of Willow Island (New Martinsville) (Figure 2.6b); however, stream stage remained very slightly higher than the aquifer water level almost year round in the lower reach of Hannibal Pool (Figure 2.6a). Water level fluctuations in the two pools across the Hannibal Dam differed significantly (Figure 2.6). Water levels in well N4 and the lower reach of Hannibal pool were almost uniform year round, in contrast to water levels in wells N1, N2, and N3 and the upper reach of Willow Island pool. 

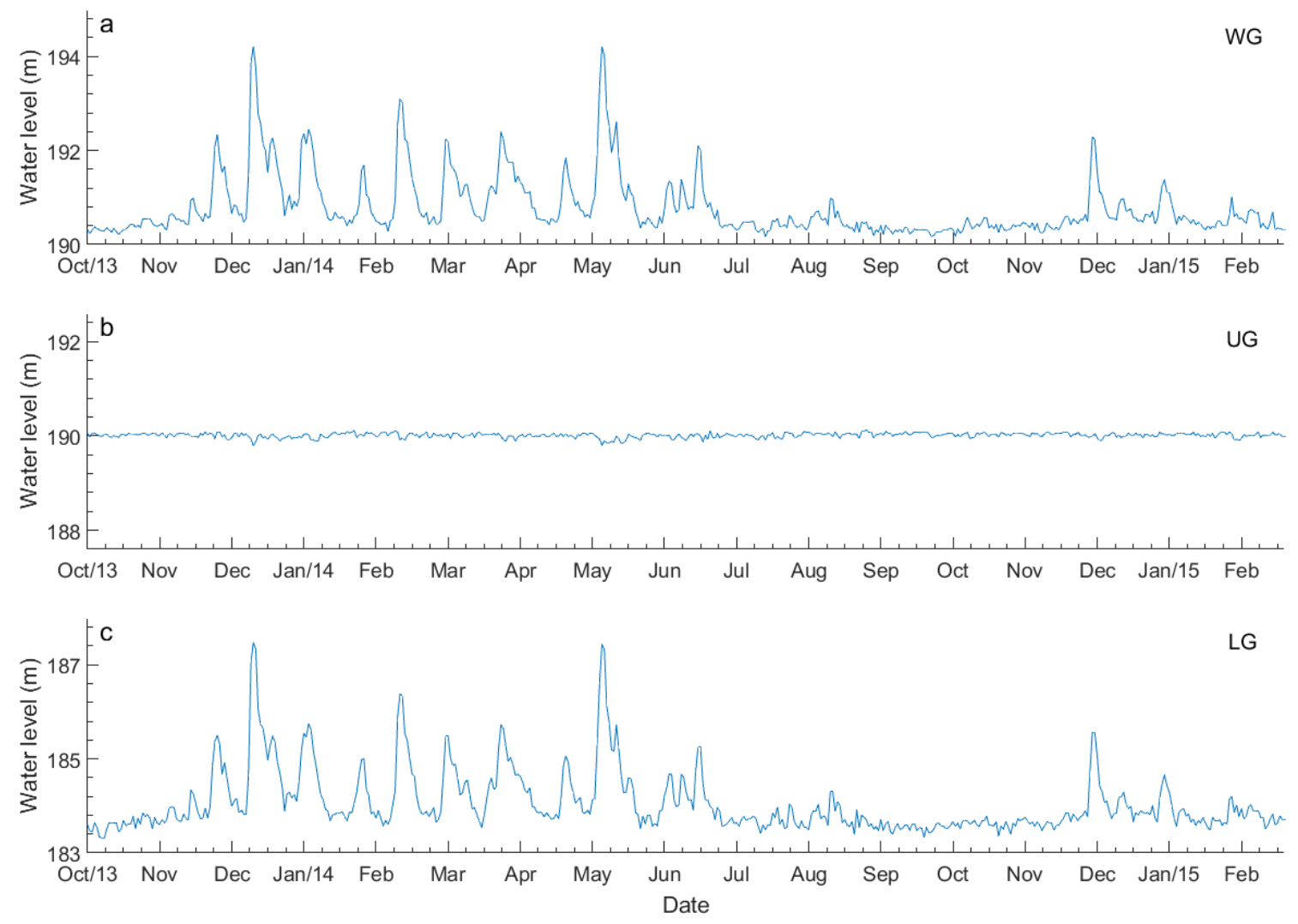

Figure 2.4 Daily maximum water levels at (a) Wheeling (WG), (b) pool upstream (UG), and (c) pool downstream (LG) of Hannibal dam from October 2013 to February 2015. 


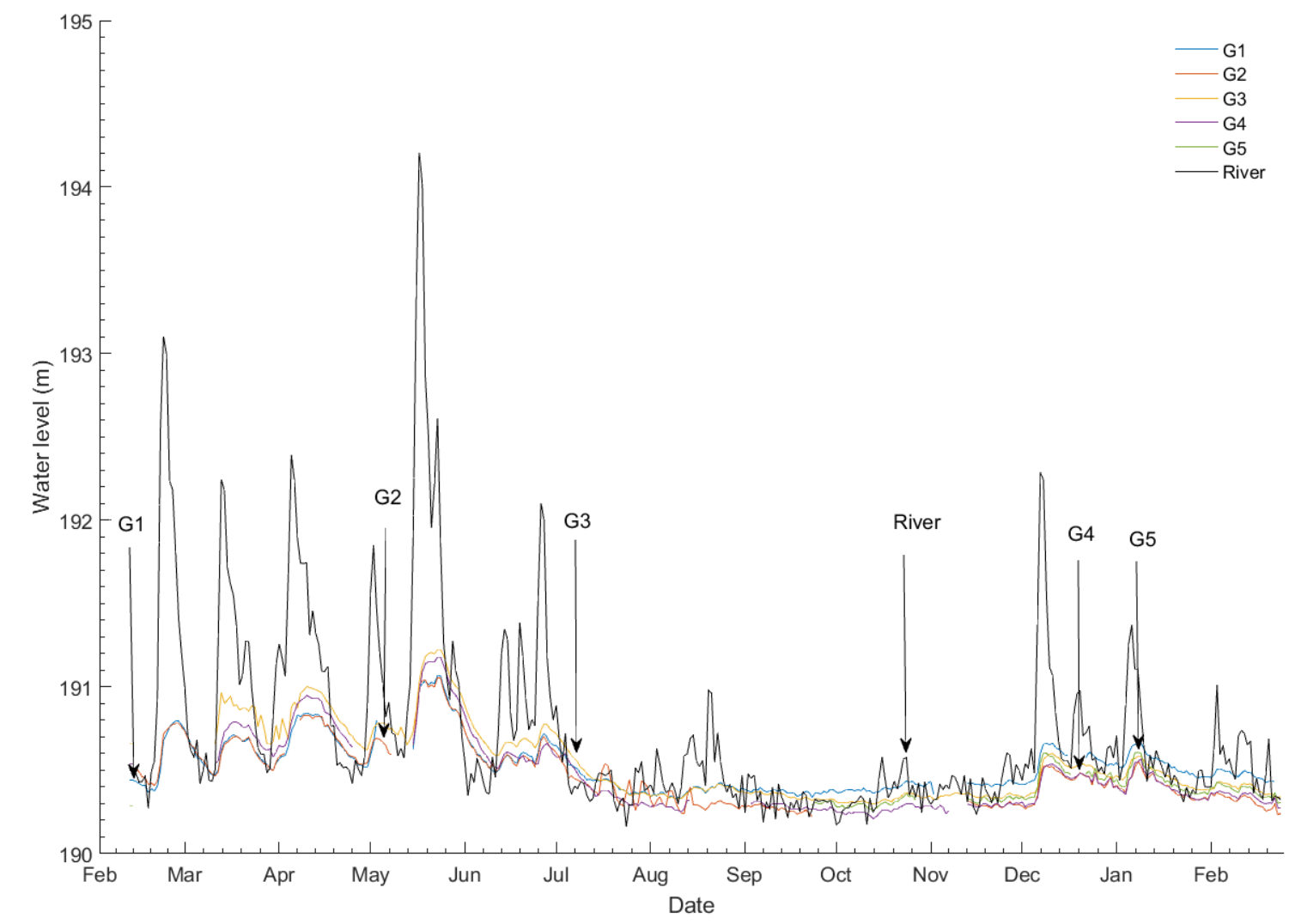

Figure 2.5 Groundwater and Ohio River stage measured at Glen Dale from February 2014 to February 2015. 

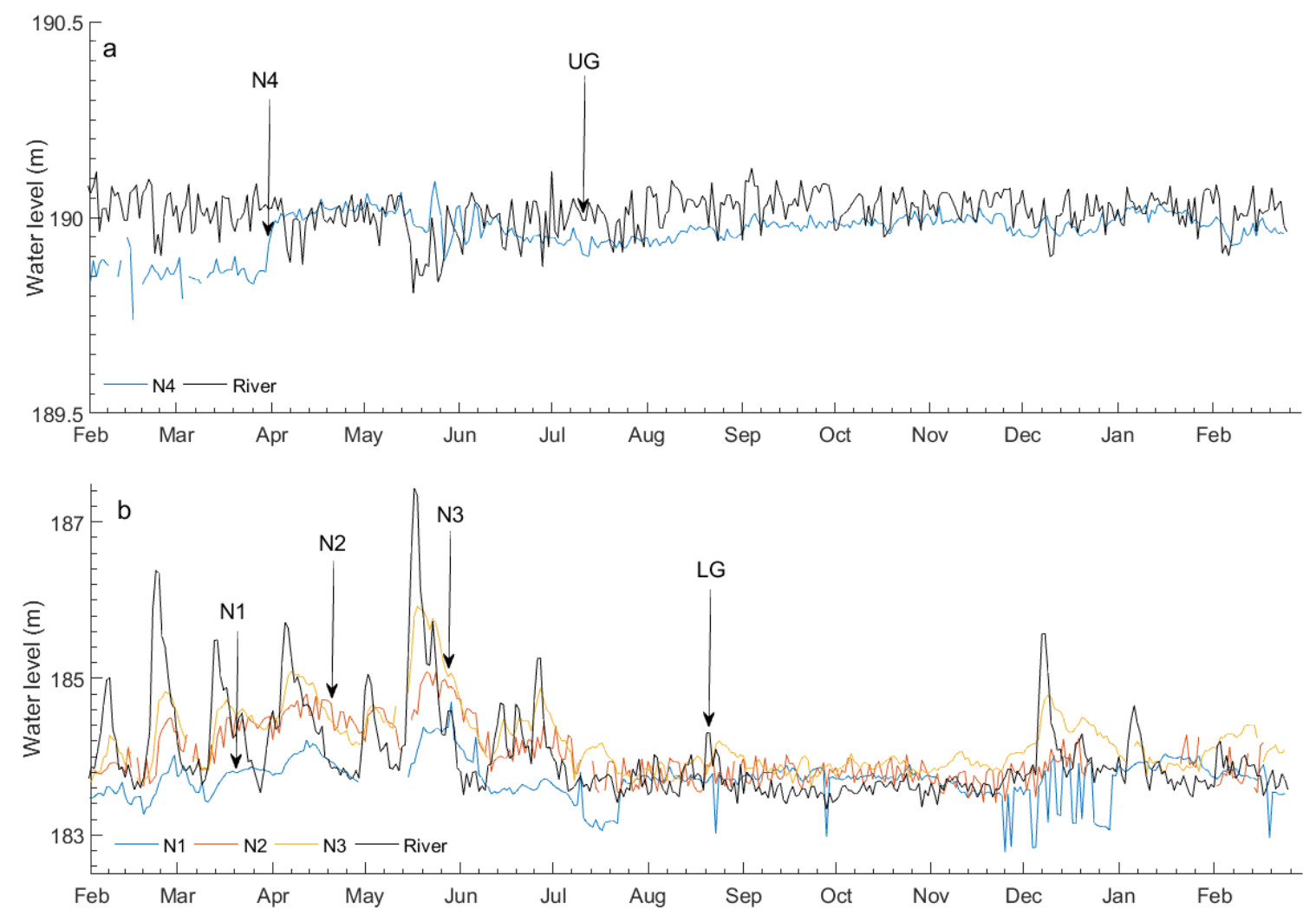

Figure 2.6 Groundwater and Ohio River stage time series from February 2014 to February 2015 at New Martinsville (a) pool upstream and (b) pool downstream of Hannibal Lock and Dam. Y-axis scale in (a) is 5 times exaggerated in comparison to (b). 
Figure 2.6 shows the stream hydrographs vary due to dam operations altering natural runoff patterns both spatially and temporally. These variations in stream stage affect groundwater-surface water interaction. During high flow, aquifer water level mimics the stream hydrograph, indicating that stream stage controls aquifer levels at these times; however, during low flow, aquifer water level is higher than river stage, indicating baseflow control.

Cross correlation and peak lag time during the high flow period (March to August 2014) were estimated for wells at Glen Dale and New Martinsville (Figure 2.7). The time series correlated significantly well except for well N4. Aquifer water level lags river stage by 14-95 hours at upper reaches but lags almost 3 months for wells adjacent to the lower reach. The lag time at different wells is positively correlated with distance from the river but negatively correlated with saturated thickness.

\subsubsection{Simulated aquifer heads driven by stream fluctuations}

\subsubsection{Glen Dale site}

Model results for wells G1 to G4 at Glen Dale yielded a range of diffusivities (Table 2.2). Following the high flow period (December 2013 to May 2014), water levels declined until December 2014 (Figure 2.8a and 2.8b). Figure 2.9 depicts model estimated induced infiltration rates and bank storage in response to stream stage fluctuations for Glen Dale aquifer. Stream fluctuations were most frequent between December 2013 and May 2014, with maximum and minimum stages of $194.2 \mathrm{~m}$ and $190 \mathrm{~m}$, respectively. Such cyclic stream fluctuations induce groundwater-surface water exchange influencing bank storage. Cumulative bank storage reached its maximum $\left(135 \mathrm{~m}^{3} / \mathrm{m}\right)$ at the end of high flow in May 2014 and declined to $42 \mathrm{~m}^{3} / \mathrm{m}$ by the end of the baseflow period. The maximum aquifer inflow and outflow rates (positive and negative, respectively) for Glen Dale were $24 \mathrm{~m}^{3} /$ day $/ \mathrm{m}$ (December 2013) and $5 \mathrm{~m}^{3} / \mathrm{day} / \mathrm{m}$ 

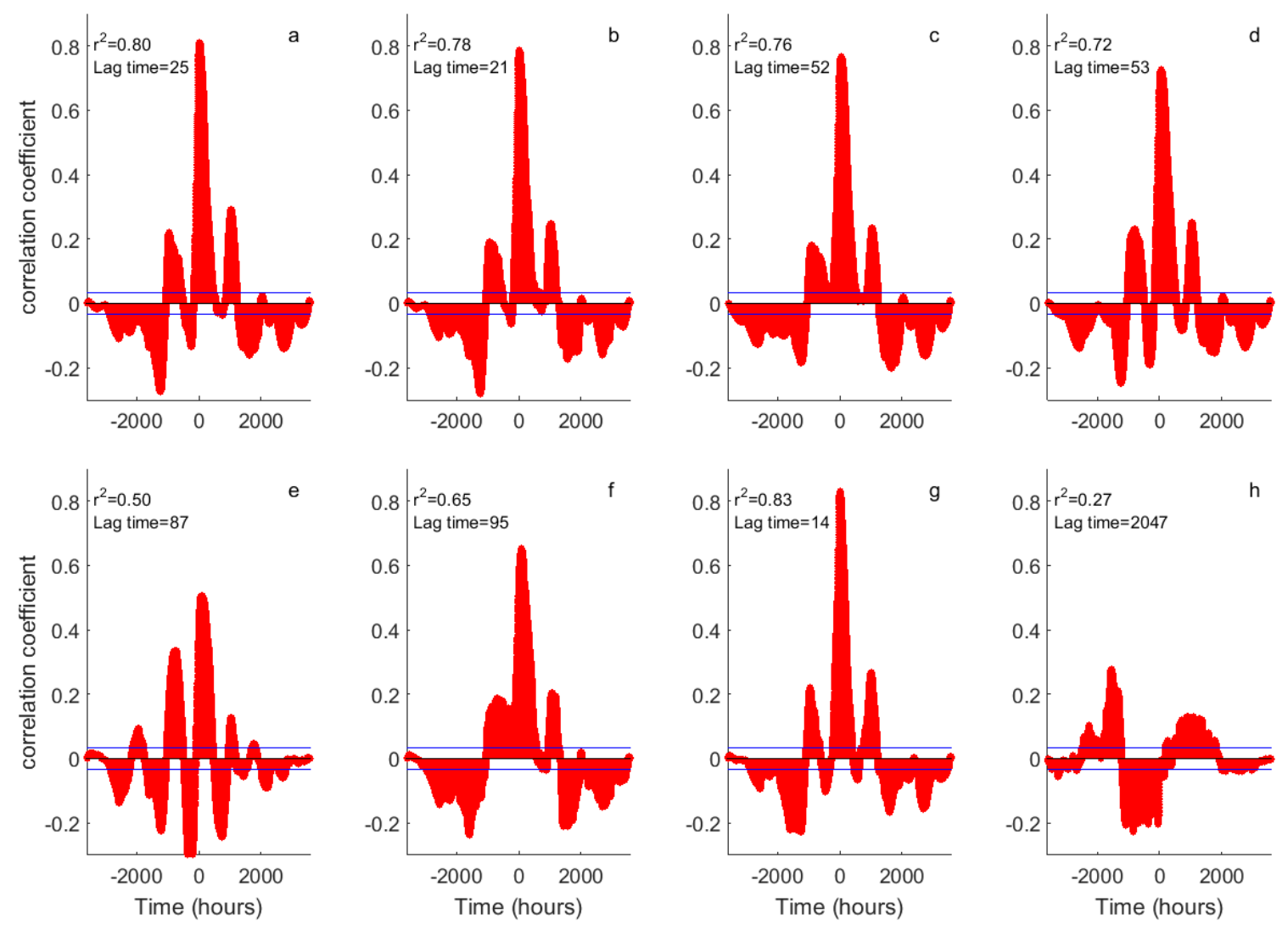

Figure 2.7 Lagged-cross correlation of aquifer response to river stage fluctuations during highflow periods (March to August 2014). Blue lines are $95 \%$ confidence intervals. Top and bottom rows (left to right) represent wells G1, G2, G3, and G4 and wells N1, N2, $\mathrm{N} 3$, and N4, respectively. 

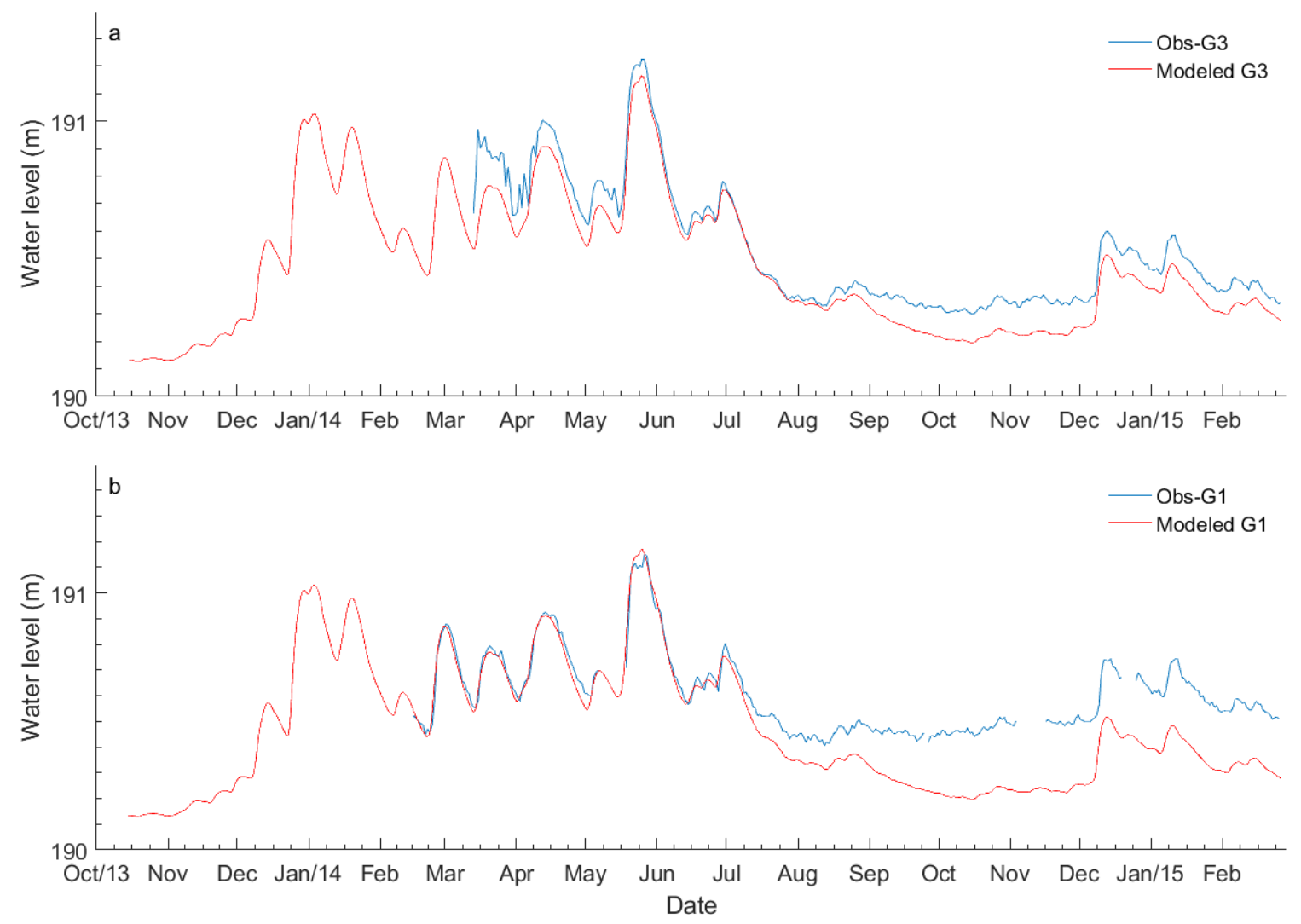

Figure 2.8 Modeled versus observed daily maximum water level at wells (a) G3 and (b) G1. 


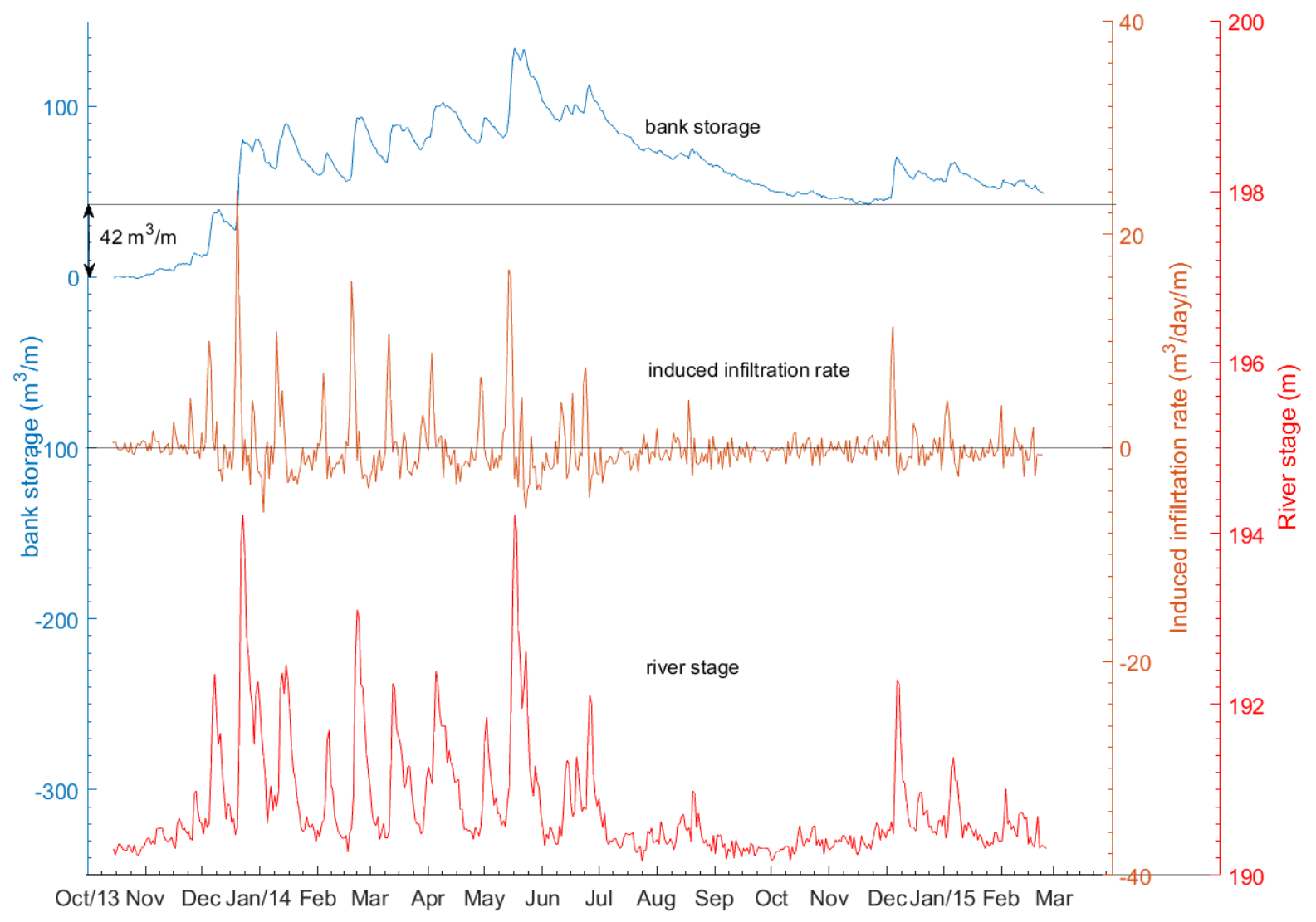

Figure 2.9 Stream stage, induced infiltration rate, and net change in storage based on well G1 at Glen Dale. 
Table 2.2 Comparison between single-peak (May 2014) stage-ratio and multiple-peak transient modeled diffusivity for Glen Dale and New Martinsville aquifers.

\begin{tabular}{|l|l|l|l|l|l|}
\hline Site & $\begin{array}{l}\text { Single- } \\
\text { peak } \\
\Delta \mathrm{H}_{\mathrm{aq}} \\
(\mathrm{m})\end{array}$ & $\begin{array}{l}\text { Single- } \\
\text { peak lag } \\
\text { time } \\
\text { (hour) }\end{array}$ & $\begin{array}{l}\text { Single-peak } \\
\text { stage-ratio } \\
\text { Diffusivity } \\
\left(\mathrm{m}^{2} / \text { day }\right)\end{array}$ & $\begin{array}{l}\text { Multiple-peaks } \\
\text { transient } \\
\text { Diffusivity } \\
\left(\mathrm{m}^{2} / \text { day }\right)\end{array}$ & $\begin{array}{l}\text { Difference } \\
(\%)\end{array}$ \\
\hline G1 & 0.64 & 25 & 5,600 & 1,000 & 82 \\
\hline G2 & 0.44 & 21 & 4,200 & 1,000 & 76 \\
\hline G3 & 0.47 & 52 & 5,400 & 3,400 & 37 \\
\hline G4 & 0.49 & 53 & 4,800 & 3,250 & 32 \\
\hline N1 & 0.64 & 80 & 6,100 & 7,500 & 23 \\
\hline N2 & 0.61 & 95 & 4,400 & 5,000 & 14 \\
\hline N3 & 1.19 & 14 & 15,500 & 4,000 & 74 \\
\hline
\end{tabular}


(January and May 2014). A few flow reversals were observed during the long recession period but of lower magnitude than those during high flow.

\subsubsection{New Martinsville site}

Upper and Lower Hannibal gage readings were used to simulate well heads in upstream and downstream aquifers from the dam, respectively (Figure 2.2). As for Glen Dale aquifer, matching of simulated to observed heads yielded a range of diffusivities (Table 2.2). The magnitude of water level fluctuations differed between the three wells (Figure 2.10a, 2.10b, and 2.10c). For example, the water level in well N4 was relatively static compared to wells N1 and N3. N1 showed lower amplitude response to flood events than N3, closer to the dam, whereas N1 and N3 had distinct high and low flow periods, but not N4. For wells N1, N3, and N4, the maximum error between modeled and observed water levels at high flow were 38, 70, and 10 $\mathrm{cm}$, respectively, but 25,45 , and $\pm 0.01 \mathrm{~cm}$ during low flow.

In contrast to Glen Dale, stream stage in the lower reach of the Hannibal Pool fluctuated little, between 189.8 and $190.1 \mathrm{~m}$ (Figure 2.11). Such minor fluctuations induced very little head difference or flow across the aquifer-stream interface. Stream stage remained nearly static at approximately $190.0 \mathrm{~m}$. Maximum aquifer outflow to the stream occurred at times of peak flow at the Wheeling gage: $3 \mathrm{~m}^{3} / \mathrm{day} / \mathrm{m}$ (December 2013) and $2.8 \mathrm{~m}^{3} / \mathrm{day} / \mathrm{m}$ (May 2014). The aquifer discharged to the stream from October 2013 to May 2014 and resumed reverse-flow conditions thereafter. Bank storage near the lower reach of Hannibal pool (N4) decreased from November 2013 to May 2014 and increased by $9 \mathrm{~m}^{3} / \mathrm{m}$ from May 2014-December 2014, the reverse of the pattern for Glen Dale (arrows in Figure 2. 11). This net loss of bank storage due to stream stage fluctuation was $8 \mathrm{~m}^{3} / \mathrm{m}$. 


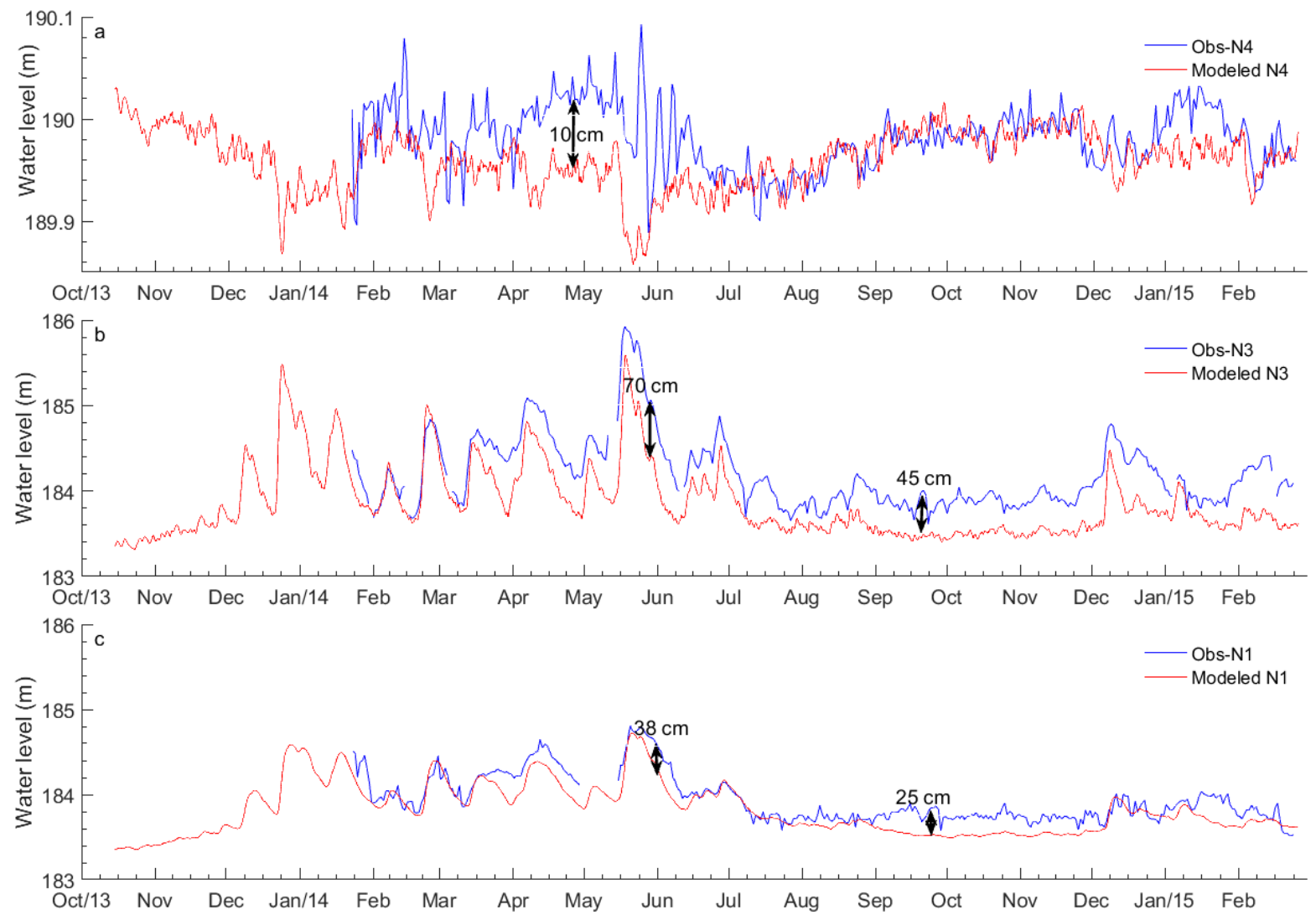

Figure 2.10 Modeled versus observed water levels at wells N1, N3, and N4 at New Martinsville. Y-axis scale in (a) is 24 times exaggerated in comparison to (b) and (c). 


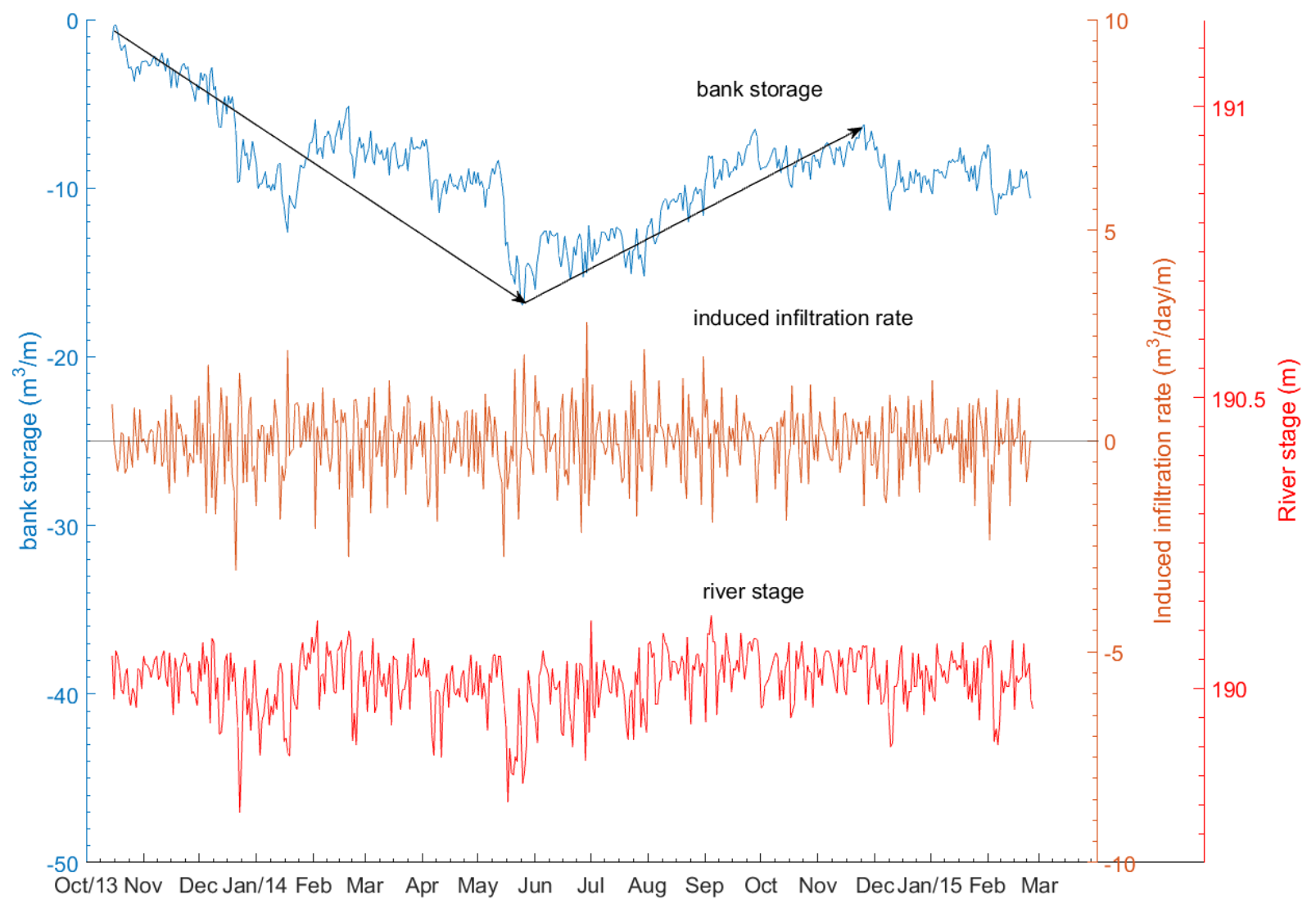

Figure 2.11 Estimated induced infiltration rate and unit-width cumulative bank storage due to river fluctuation at the lower reach of the Hannibal pool near well N4. 
Stream stage fluctuations, induced infiltration rates, and cumulative bank storage at the upper reach of Willow Island pool (well N3) were identical to that at Glen Dale (Figure 2.12). Stream stage rose by up to $4 \mathrm{~m}$, increasing bank storage to approximately $140 \mathrm{~m}^{3} / \mathrm{m}$ at the end of high flow. Estimated maximum aquifer inflow and outflow rates were $46 \mathrm{~m}^{3} / \mathrm{day} / \mathrm{m}$ (December 2013) and $10 \mathrm{~m}^{3} / \mathrm{day} / \mathrm{m}$ (January and May 2014), almost twice that of Glen Dale. Unlike Glen Dale aquifer, bank storage at the end of recession was approximately $-3 \mathrm{~m}^{3} / \mathrm{m}$.

\subsubsection{Model parameters}

The multiple-peaks transient diffusivities for Glen Dale and New Martinsville wells ranged between 1,000 and 7,500 $\mathrm{m}^{2} / \mathrm{day}$. In comparison, the single-peak stage-ratio diffusivity for the same wells ranged between 4,200 and $15,500 \mathrm{~m}^{2} / \mathrm{day}$. The former values differed from the latter ones by $14-82 \%$ with respect to the latter ones at these sites (Table 2.2).

\subsection{Discussion}

\subsubsection{Spatial differences in groundwater-stream interaction}

A year-long dataset of stream stage shows frequent peaks related to flooding events at high flow in the upper reaches of both Hannibal and Willow Island pools (Figure 2.4a and 2.4c). At the lower reach of the Hannibal Pool, however, stream stage is clearly regulated by dam operations (Figure 2.4b). High and low flow periods are distinguishable for the former but indistinguishable for the latter. A fundamental difference in the observed stream forcing signal is related to, in this case, dam location and operations. Because of this difference in forcing, water levels in LG and UG, across the Hannibal Dam, are inversely correlated (Figure 2.6). It is likely that, at some place upstream from the dam, a transition from runoff-dominated to regulation dominated conditions exists, suggesting that distinctly different zones with respect to groundwater-surface water interaction prevail along the Ohio River. 


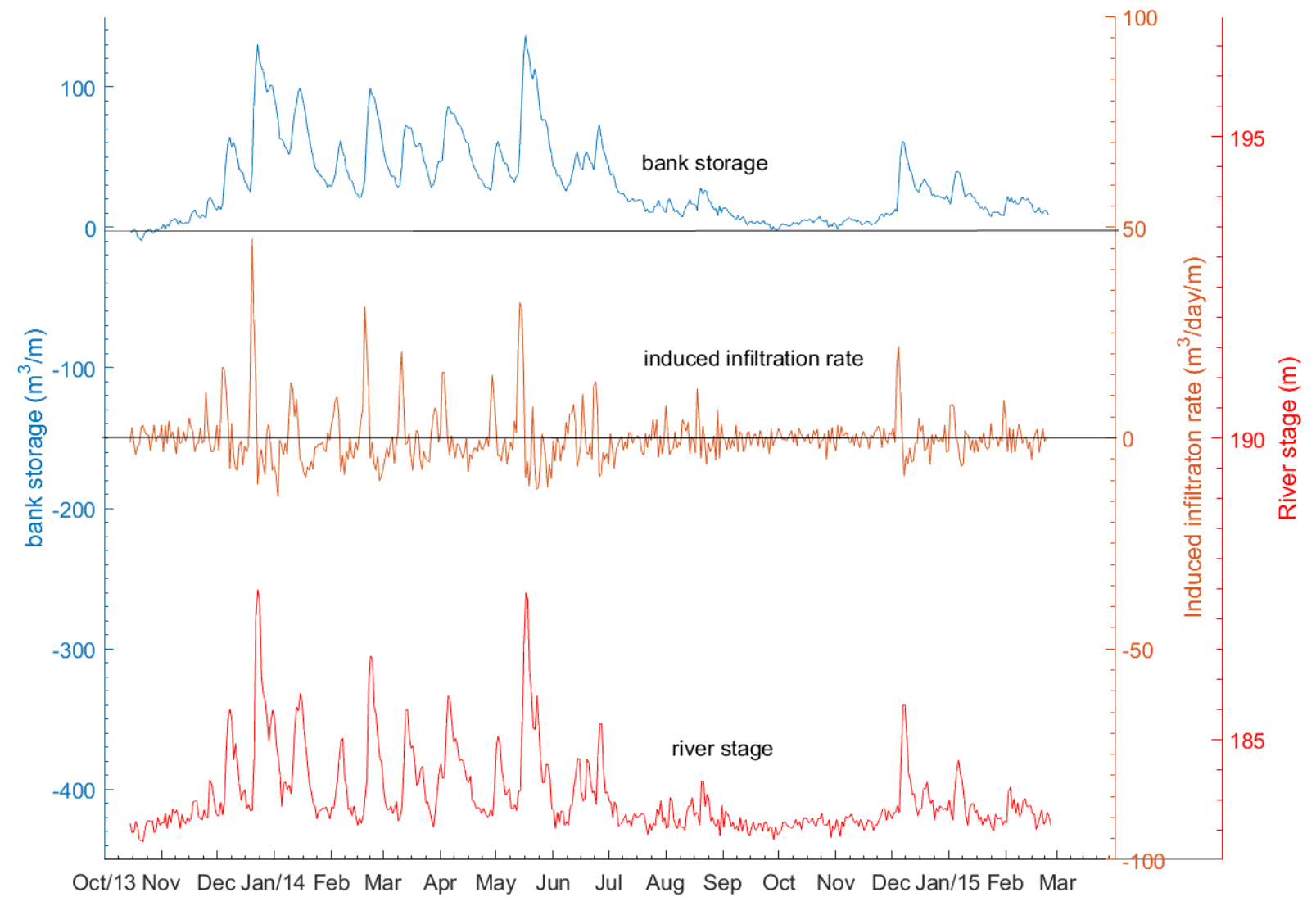

Figure 2.12 Induced infiltration rate and net change in storage due to river fluctuation around well N3 in the upper reach of the Willow Island pool. 
Wells in Glen Dale and New Martinsville at different distances from the stream responded differently to stream stage fluctuations, particularly when it was higher than that in the aquifer (Figure 2.5 and 2.6). Generally, wells closest to the stream had higher-amplitude head fluctuations than those at distance, as would be expected. During low flow, aquifer and stream stage fluctuations were infrequent and of small amplitude, showing recession with the hydraulic gradient toward stream, i.e. baseflow conditions.

\subsubsection{Temporal differences in groundwater-stream interaction}

Model-simulated aquifer heads at Glen Dale and New Martinsville (Figure 2.8 and 2.10) in most cases matched observed heads well during high-flow periods, but tended to deviate from congruence later in the recessional period. An exception is well N4 which showed a better fit in summer through fall 2014, when flows were actually rising due to stream regulation (note that well N4 head is at greatly larger scale than for the other wells) (Figure 2.10). The match tended to be much poorer later in the year during recessional periods, and the observed heads at these times tended to be underestimated by the model consistently. A major cause for this may be inherent bias in the method of calibration, which focused on wiggle-matching of hydrograph peaks that were more common in high flow periods.

The differences at low flow between observed and simulated water levels might be ascribed to boundary conditions (pumping, recharge, etc) not incorporated into the analytical model, in addition to error in model assumptions. However, the relatively good match between modeled and observed water levels during high-flow periods in all wells but N4 suggest that prominent stream flood-event forcing is sufficient to mask recharge during these periods. Therefore, this analytical method using longer periods of actual stream and aquifer data seems to be most appropriate to fitting and parameter estimation using frequent stream high-flow events. 
The variation of aquifer diffusivities from the peak-matching model suggests heterogeneity within and between the two sites (Table 2.2). This is due to lack of independent sources of storage parameter estimates which could vary over time and across thickness of unconfined aquifers (Pool and Eychaner, 1995); or perhaps wells being at different distances from the stream (Noorduijn et al., 2014); or due to subsurface structures (Welch et al., 2014). Distant wells tended to display higher aquifer diffusivity than those close to the stream. This analytical model used simplified aquifer geometry and neglected pumping and recharge that could well play an important role in aquifer behavior, especially at low recessional flow. However, drawdown recovery for those wells were nearly instantaneously after pumping indicating that low-rate intermittent pumping had a minimal effect on aquifer hydraulic heads. Further, numerical and chemical modeling are required to account for other complex boundary conditions. However, simulated aquifer heads tend to agree with measured heads within the distance of bank storage gain created by induced infiltration, as demonstrated by the model.

\subsubsection{Effects of dam operation}

Dam operations in this study caused upper reaches of pools to behave as a fluctuating stream and the lower reaches to behave more like a non-fluctuating lake, maintaining an almost constant stage year-round. Such behavior has implications for groundwater-surface water exchange, with upper-reach aquifers gaining water during high flow periods and losing it during low flow. However, lower-reach aquifers (as in the lower Hannibal pool) showed bank storage losses during spring and gains during summer, both at a much lower rate than upper pools (Figure 2.11). The head difference across the dam promotes groundwater to flow parallel to the stream not perpendicular, which violates the assumptions of the analytical model. The well N3 displayed higher head fluctuations as well as greater deviation between simulated and observed 
heads than that of well N1 (Figure 2.9). The hydraulic gradients from the Hannibal to Willow Island Pool, parallel to the stream, varied from 0.001 to 0.002 during low and high flow periods. The higher hydraulic gradient infers higher rates of groundwater flow.

\subsection{Conclusions}

Groundwater response to stream stage fluctuations was studied in shallow unconfined alluvial aquifers along the regulated Ohio River. A year-long dataset of stages from three stream gages in two pools were collected, as well as 10 wells in two PWS systems near these gages. Field data and modeling results show well heads close to the stream fluctuate more than those farther away from the aquifer-stream boundary.

Bank storage gains were induced by stream fluctuation, especially during high flow periods and at the upper reaches of the pools. Very minor variations in stream stage were observed in the lower reaches of these pools near dams, an order of magnitude less than in the upper reaches of pools. The exchange rate for lower reaches was small and out of phase (i.e., in the opposite direction) with respect to the upper reaches of the same pool. Therefore, groundwater-surface water interaction appears to be spatially and temporally variable along the regulated stream.

Aquifer diffusivities estimated by wiggle matching simulated peaks using the transient analytical model to stage-ratio diffusivity. Irregular amplitudes of groundwater fluctuations and a wide range of estimated aquifer diffusivity values for different wells in the same well field suggest heterogeneous aquifer conditions, which could not be assessed using the homogeneitybased analytical model. Further, numerical and chemical modeling are required to account for other complex boundary conditions. During high-flow periods, simulated aquifer heads using 
stream stage fluctuation without recharge matched observed heads reasonably well at the upper reaches of pools. However, modeled heads during baseflow deviated substantially from measured heads, almost certainly due to unaccounted boundary conditions present in reality but unaccounted for in this model.

Actual induced infiltration rate and bank storage could differ significantly from those estimated by this model where significant recharge partial penetration, regional gradient, or heterogeneity are present. Nonetheless, this method confirms that locations along streams where enhanced groundwater-surface water exchange may be induced. This method seems to give meaningful results in an area where large flood peaks create apparent reversals of flow into adjacent high-conductivity alluvium. 


\section{Temperature variations in intermittently-pumped wells within}

\section{unconfined alluvial aquifers}

\section{Chapter Abstract}

Temperature fluctuations in response to high-frequency intermittent pumping were observed from February 2014 to August 2016 in 14 wells in three shallow, unconfined, alluvial aquifers along the Ohio River. This study demonstrates 2-component temperature signals inside pumping wells varying between pump-on and pump-off periods. Both components vary seasonality at different magnitudes. While pump-off temperatures fluctuated up to $3.8^{\circ} \mathrm{C}$ seasonally, short-term temperature shifts induced by turning the pump on were 0.2 to $2.5^{\circ} \mathrm{C}$. The short-term temperature shifts were highest in magnitude in summer and winter because groundwater lagged behind surface water temperature in average by six months for majority of the wells and ranged from 140 to 270 days. The short-term and seasonal temperature shifts were spatially and temporally complex. However, the short-term temperature shifts indicate that pumping always induce water with contrary temperature to that of groundwater. This result confirms that stream exfiltration is a major source of water budget to a number of these wells. 


\subsection{Introduction}

Surface water exfiltration in response to well pumping has the potential to degrade aquifer water quality (Brunke and Gonser, 1997) or alter surface and/or groundwater budgets (Chen and Yin, 2001; Sophocleous, 2002). Heat has been used to delineate such exchanges over small spatial scales because temperature fluctuations near the surface can be large and rapid (Constantz and Stonestrom, 2003). Heat can transfer between two media via radiation, convection, conduction, or advection, but advection is the most useful for tracing groundwater flow (Constantz, 1998).

Pumping can reduce or even eliminate baseflow to a gaining stream (Chen and Yin, 2001) or induce stream exfiltration to an aquifer (Barlow and Leake, 2012). Such reversals of flow may be driven by river stage rise due to either flooding or stream regulation (Lewandowski et al., 2009; Maharjan and Donovan, 2016). Intermittent well pumping may influence groundwater flow path and velocity (Spane and Mackley, 2011; Walker, 2001). Sheets et al. (2002) observed that groundwater flow to production wells had shorter and more consistent travel times under continuous rather than intermittent pumping. Both styles of pumping may deplete streamflow (Jenkins, 1968) but in different fashions (Wallace et al., 1990).

The amplitude of groundwater temperature decreases and lag time increases with increasing depth and distance from the stream (Bartolino, 2003).Temperature tends to penetrate to a greater depth where groundwater flow is downward compared to upward (Taniguchi, 1993). Zurawski (1978) observed that temperature in an alluvial aquifer lagged about 6 months behind stream temperature. 
Heat has been extensively used to trace vertical advective fluid flow through porous media (Lapham, 1989; Silliman and Booth, 1993; Constantz et al., 1994; Constantz, 1998; Stonestrom and Constantz, 2003; Constantz, 2008). Most of these studies were performed in hyporheic exchange zones and measured vertical temperature variations beneath streambeds to depths $<2$ meters. However, heat transport in advective flow of stream exfiltration through its bank has been less studied. This study examines temperature time series from intermittentlypumped wells in shallow unconfined aquifers near a leaky stream. Such thermal behavior has the potential to shed light on the connection between groundwater and surface water exchanges induced by pumping. We hypothesize, if pumping causes surface water to exfiltrate, this could be identified by the temperature of produced water differing from other sources of groundwater.

The study area is a series of discontinuous gravel aquifers along the Ohio River Valley of West Virginia tapped by wells in three public water supply (PWS) systems: New Martinsville, Glen Dale, and McMechen (Figure 3.1a, b, and c). The Pleistocene-age Ohio River incised bedrock of Permo-Pennsylvanian age to form the modern valley (Prellwitz, 2004). Quaternary sediment filled its valley with unconsolidated sand, gravel, silt, and clay (Carlston, 1962; Simard, 1989; Rogers, 1990). The basal portion of the valley is composed of coarse-grained gravel underlain by finer sediments. Quaternary-age terraces form the land surface as floodplain deposits, which also extend up the major tributaries.

Groundwater in McMechen, Glen Dale, and New Martinsville is intermittently pumped at approximately $6,000,2,000$, and $8,000 \mathrm{~m}^{3} /$ day, respectively, using combinations of 11 wells completed near the base of the aquifer. McMechen has four concurrently-pumped wells in two rows nearly parallel to the river. Glen Dale has four observation and two production wells, 

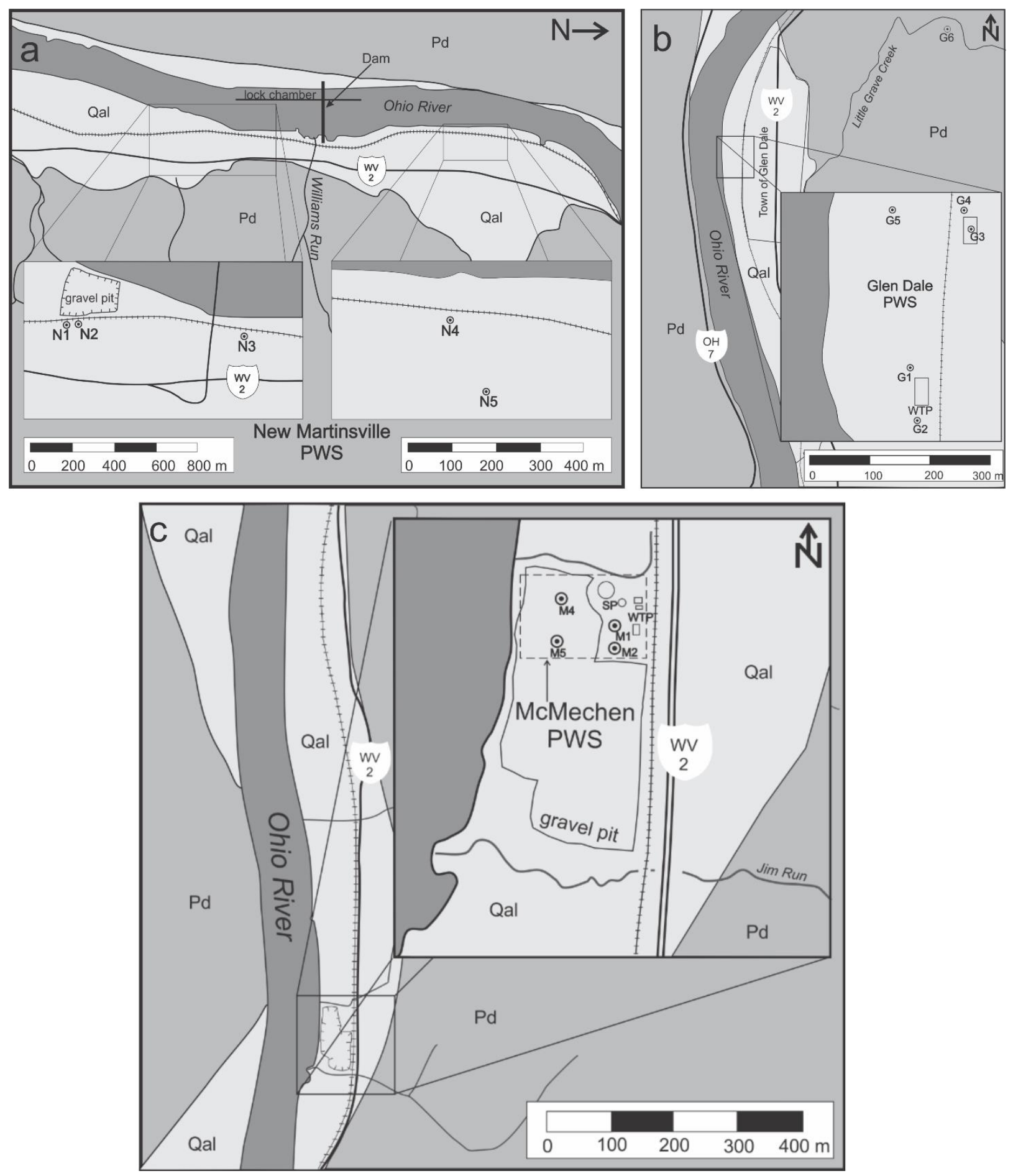

Figure 3.1 Site map of New Martinsville, Glen Dale, and McMechen PWS systems showing wells (numbered circles). Abbreviations: $\mathrm{Pd}=$ Dunkard Group (Permian); Qal=Quaternary alluvium; $\mathrm{SP}=$ sewage plant (circles); WTP=water treatment plant (rectangles) 
pumped intermittently one at a time with weekly rotation. New Martinsville has five pumping wells, of which two (N4 and N5) alternate operation.

The south-flowing Ohio River forms nearly-level pools along the channel. Hannibal Locks and Dam at New Martinsville forms a 68-km long pool which is adjacent to 11 of the 14 wells. Wells are 70 to $160 \mathrm{~m}$ distant from the river in McMechen, 110 to $250 \mathrm{~m}$ in Glen Dale, and 90 to $270 \mathrm{~m}$ in New Martinsville. The New Martinsville well field has three wells (N1, N2, and N3) from 750 to 1,600 m downstream of the dam and two (N4 and N5) 1,500 to 1,600 m upstream of it. Table 3.1 summarizes locations and characteristics of pumping and observation wells employed.

\subsection{Methods}

Groundwater temperatures and water levels response to intermittent pumping were measured in the 14 wells using data logger-coupled sensors. Data were collected at one-minute intervals from February 2014 to February 2016 and then at hourly intervals until August 2016. Also during this period, air temperature was measured in a well with the sensor $1.52 \mathrm{~m}$ below the surface. 15-minute-interval stream temperature was compiled from January 2014 to November 2016 from a gaging station in Montgomery Pool, 60 miles upstream from Glen Dale along the Ohio River. The pressure transducers used in wells were vented Global Water® WL-16 and sealed Onset ${ }^{\circledR}$ U020 (Table 3.1). The sealed loggers were used in outdoor wells in Glen Dale PWS. The vented transducers have pressure and temperature accuracy of $\pm 1 \mathrm{~cm}$ and $\pm 0.28^{\circ} \mathrm{C}$; the sealed ones are $\pm 3 \mathrm{~cm}$ and $\pm 0.44^{\circ} \mathrm{C}$. The loggers were downloaded monthly and converted to hydraulic heads using standard techniques (Weight and Sonderegger, 2001). Water level depth below the well measuring point was measured periodically with an electric tape $( \pm 5 \mathrm{~mm})$ to verify transducer readings. Lag time ( $\tau$ days) between groundwater and stream temperature was 
Table 3.1 Well characteristics, lag times $(\tau)$, and temperature shifts observed in wells at the 3 PWSs.

\begin{tabular}{|c|c|c|c|c|c|c|c|c|c|c|c|c|c|}
\hline $\begin{array}{l}\mathrm{P} \\
\mathrm{W} \\
\mathrm{S}\end{array}$ & ID & $\begin{array}{c}\text { TOC } \\
\text { (m) }\end{array}$ & $\begin{array}{c}\mathrm{Q} \\
\left(\mathrm{m}^{3} /\right. \\
\text { day) }\end{array}$ & $\begin{array}{l}\text { SWL } \\
\text { (m) }\end{array}$ & $\mathrm{b}(\mathrm{m})$ & $\begin{array}{l}\text { screen } \\
\text { length } \\
(\mathrm{m})\end{array}$ & $\mathrm{z}(\mathrm{m})$ & $\begin{array}{r}\mathrm{L} \\
(\mathrm{m})\end{array}$ & $\begin{array}{c}\tau \\
\text { (days) }\end{array}$ & $\begin{array}{c}\text { Seasonal } \\
\text { Max temp } \\
\left({ }^{\circ} \mathrm{C}\right)\end{array}$ & $\begin{array}{c}\text { Seasonal } \\
\text { Min temp } \\
\left({ }^{\circ} \mathrm{C}\right)\end{array}$ & $\begin{array}{l}\text { PITS } \\
\left({ }^{\circ} \mathrm{C}\right)\end{array}$ & $\begin{array}{l}\text { STS } \\
\left({ }^{\circ} \mathrm{C}\right)\end{array}$ \\
\hline \multirow{5}{*}{ 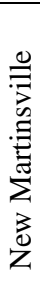 } & N1 & 192.0 & 1,900 & 10.9 & 6.7 & 3.6 & 11.7 & 270 & 180 & 13 & 12.1 & 0.2 & 0.9 \\
\hline & $\mathrm{N} 2$ & 192.6 & 1,635 & 11.7 & 6.2 & 3.6 & 12.8 & 250 & 180 & 14.3 & 12.4 & 0.25 & 1.9 \\
\hline & N3 & 196.0 & 2,180 & 13.1 & 9.6 & 4.5 & 17.5 & 90 & 180 & 15.4 & 11.7 & 2.5 & 3.7 \\
\hline & N4 & 195.4 & 2,589 & 6.2 & 16.6 & 6.1 & 8.5 & 105 & 140 & 13.8 & 11.5 & 0.6 & 2.3 \\
\hline & N5 & 197.5 & 2,180 & 8.4 & 12 & 2.7 & 13.7 & 270 & 210 & 12.6 & 10.8 & 0.4 & 1.8 \\
\hline \multirow{6}{*}{$\frac{\frac{u}{\pi}}{\frac{0}{0}}$} & G1 & 199.6 & 2,071 & 9.3 & 15.1 & 7.6 & 15.1 & 140 & 215 & 12.8 & 11.6 & 0.2 & 1.2 \\
\hline & G2* & 199.0 & 2,071 & 9.1 & 15.2 & 7.6 & 14.6 & 146 & - & - & - & - & - \\
\hline & G3 & 204.5 & N/A & 11 & 13.1 & N/A & 15.1 & 250 & 270 & 12.8 & 11.8 & N/A & 1 \\
\hline & G4 & 203.9 & N/A & 12.9 & 12.3 & N/A & 19.8 & 230 & 0 & 14.7 & 14.7 & N/A & 0 \\
\hline & G5 & 197.2 & N/A & 6.6 & 2.8 & N/A & 8.5 & 110 & 170 & 15.7 & 13.9 & N/A & 1.8 \\
\hline & G6 & 218.5 & 163 & 3 & 22.3 & N/A & 10.2 & $\mathrm{~N} /$ & 165 & 14.2 & 11.6 & N/A & 2.6 \\
\hline \multirow{6}{*}{$\begin{array}{l}\frac{0}{0} \\
\sum_{0}^{0} \\
\sum\end{array}$} & M1 & 202.0 & 1,226 & 12.9 & 6.8 & 4.9 & 19.8 & 155 & - & - & - & - & - \\
\hline & M2 & 202.1 & 1,635 & 13.1 & 6.6 & 4.9 & 16.1 & 160 & - & - & - & - & - \\
\hline & M4 & 197.0 & 1,635 & - & - & 5.3 & - & 75 & - & - & - & - & - \\
\hline & M5 & 197.3 & 1,771 & 8.4 & 12.9 & 5.3 & 14.2 & 70 & 180 & 16.1 & 12.3 & 0.3 & 3.8 \\
\hline & Riv & 204.2 & N/A & N/A & N/A & N/A & N/A & 0 & 0 & 28 & 0 & N/A & 28 \\
\hline & Air & 203.9 & N/A & N/A & N/A & N/A & N/A & 230 & 15 & 25 & 5 & N/A & 20 \\
\hline
\end{tabular}

*Thermal data unavailable; TOC = top of casing elevation; $\mathrm{Q}=$ average pumping rate; $\mathrm{SWL}=$ static water level; $b=$ saturated thickness of aquifer; $z=$ sensor depth; $L=$ well distance from a stream; $\tau=$ Lag time; PITS=pumping-induced temperature shift; STS=seasonal temperature shift 
estimated by visual-peak-matching, shifting one time series versus the other, with estimated uncertainty of \pm 5 days.

\subsection{Results}

Figure 3.2 illustrates lithologic summaries of drillers' logs for five pumping wells in the New Martinsville PWS (Figure 3.1). Hannibal Lock and Dam lies between wells N3 and N4. Each log recorded three lithologies: sand, gravel, and boulders; sand and gravel; and silt and clay. Lithology becomes coarser-grained with depth. Wells were drilled and screened in the basal gravel unit overlying bedrock, at different depths. The potentiometric head in the aquifer upstream of the dam is higher than downstream. Similarly, surface elevation is lower toward the south along the river.

Figure 3.3a shows flowlines in an unconfined alluvial aquifer with a single pumping well at distance $\mathrm{L}$ from a stream. A pressure/temperature sensor is set in the well at depth $\mathrm{z}$ below ground surface. A cone of depression developed in response to pumping intercepts the river and indicates exfiltration is being induced. Fluid flow to the well is dominantly horizontal in the screened interval and dominantly vertical above it perhaps due to anisotropy of the aquifer materials.

Figure 3.3b illustrates hypothesized for heat-transfer mechanisms in the aquifer of Figure 3.3a. The surface and subsurface temperatures differ and both fluctuate seasonally. Heat can either be added or removed at the surface-subsurface interface by radiation (double-headed arrows). Changes in subsurface temperature are slow and form nearly-horizontal isotherms in this radiation zone. Groundwater entering the well by advection from the river may reflect 


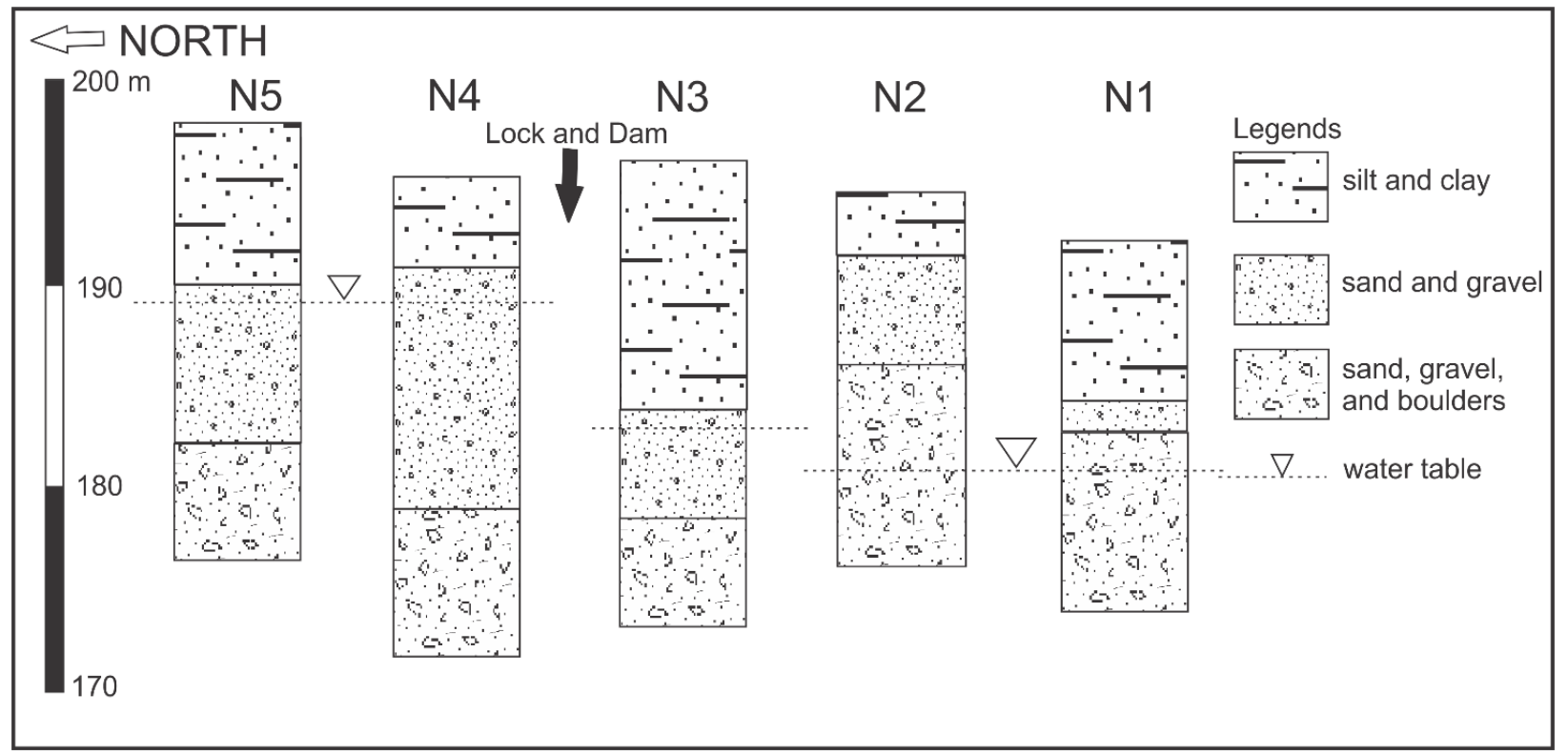

Figure 3.2 Generalized logger well logs from New Martinsville PWS showing water levels (Source: file data, New Martinsville PWS, Courtesy David Benson) 

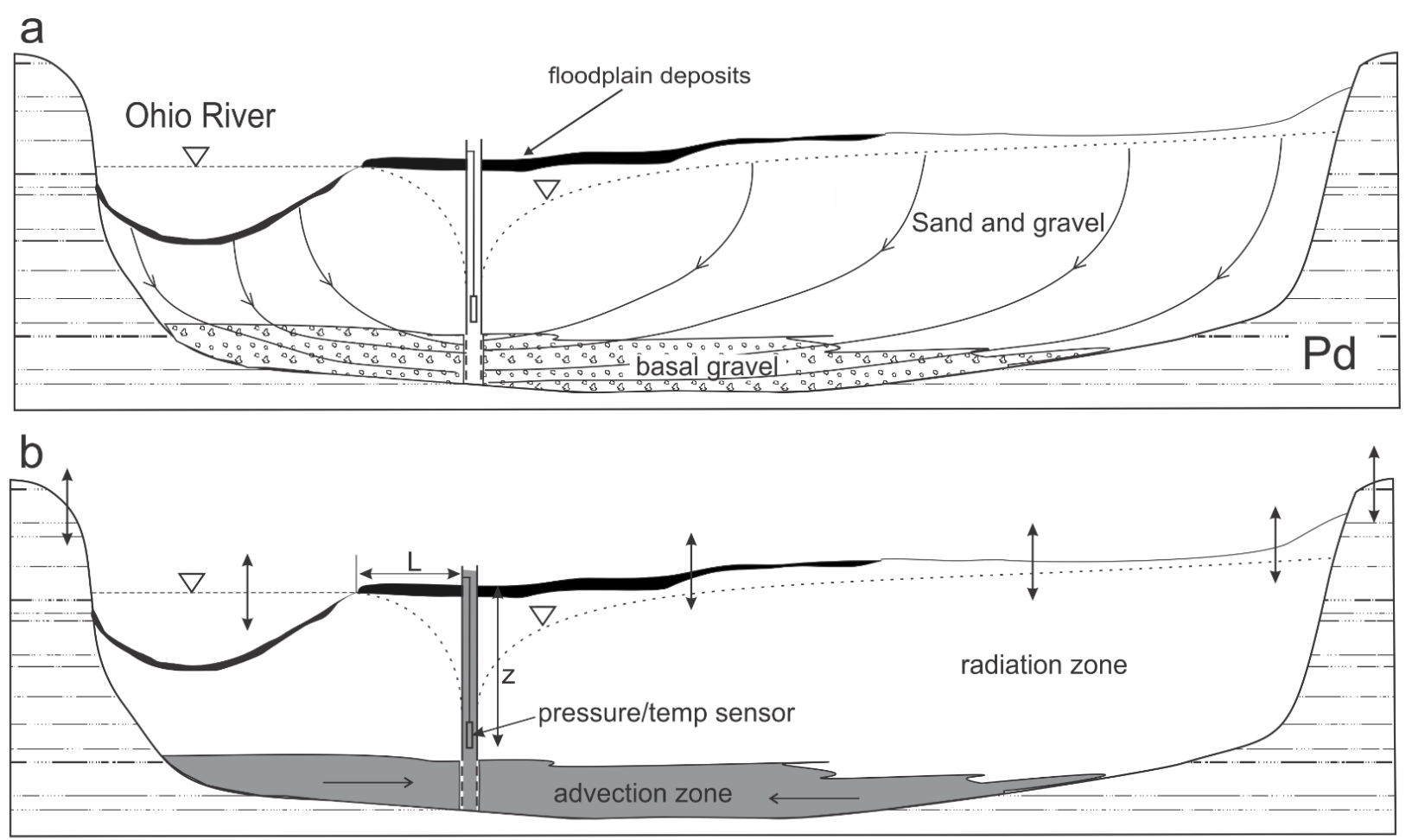

Vertical Exaggeration $=10 x$

Figure 3.3 A conceptual geological cross-section of the Ohio River valley with (top) a pumping well and associated flow lines and (bottom) inferred heat transport mechanisms. 
stream temperature rather than that of the aquifer surface (single-headed arrow). In this horizontal flow zone, it is speculated that isotherms would be vertical.

Observed water-level variations during pumping of well M5 from May 2014 to August 2016 are shown as light-grey bands (Figure 3.4). This well was intermittently pumped at high frequency followed by 8 - to 10-minute recovery periods, generally too brief to be visible on the scale of figure 3.4. Labels 1 (upper edge of light-grey bands) and 2 (lower edge) indicate nonpumping (recovery/pump off) and pumping (pump on) water levels, respectively. The separation between 1 and 2 (i.e. the height of the light-grey band) is drawdown due to pumping, i.e. the sum of aquifer and well losses. The magnitude of this drawdown was approximately uniform during the period shown. Thus, the pump-on and pump-off water levels tend to be parallel even as the aquifer water level varies from time to time. During recovery (i.e. Label 1), the water level represents that of the aquifer itself, which was higher in spring than in fall. The bottom of the light-grey band represents aquifer water level less well-loss drawdown. Although not apparent in this figure, when the pump turns off, the well losses are immediately recovered and the well head re-equilibrates with the surrounding aquifer, whose level is at all times below stream stage in the vicinity of this well field.

Temperature variations in the well during and after pumping appear as vertical dark-grey bands (Figure 3.4). The period showing no band represents a data gap (Label 3). Labels 4 and 5 indicate temperatures at pump-on and pump-off times, respectively. The appearance of temperature as a band is simply due to high-frequency pumping. The magnitude of temperature fluctuations generated by such high-frequency pumping was seasonally non-uniform and highest during summer and winter (double-headed arrows). High water levels appear to correlate with some (asterisk), but not all, temperature peaks. 


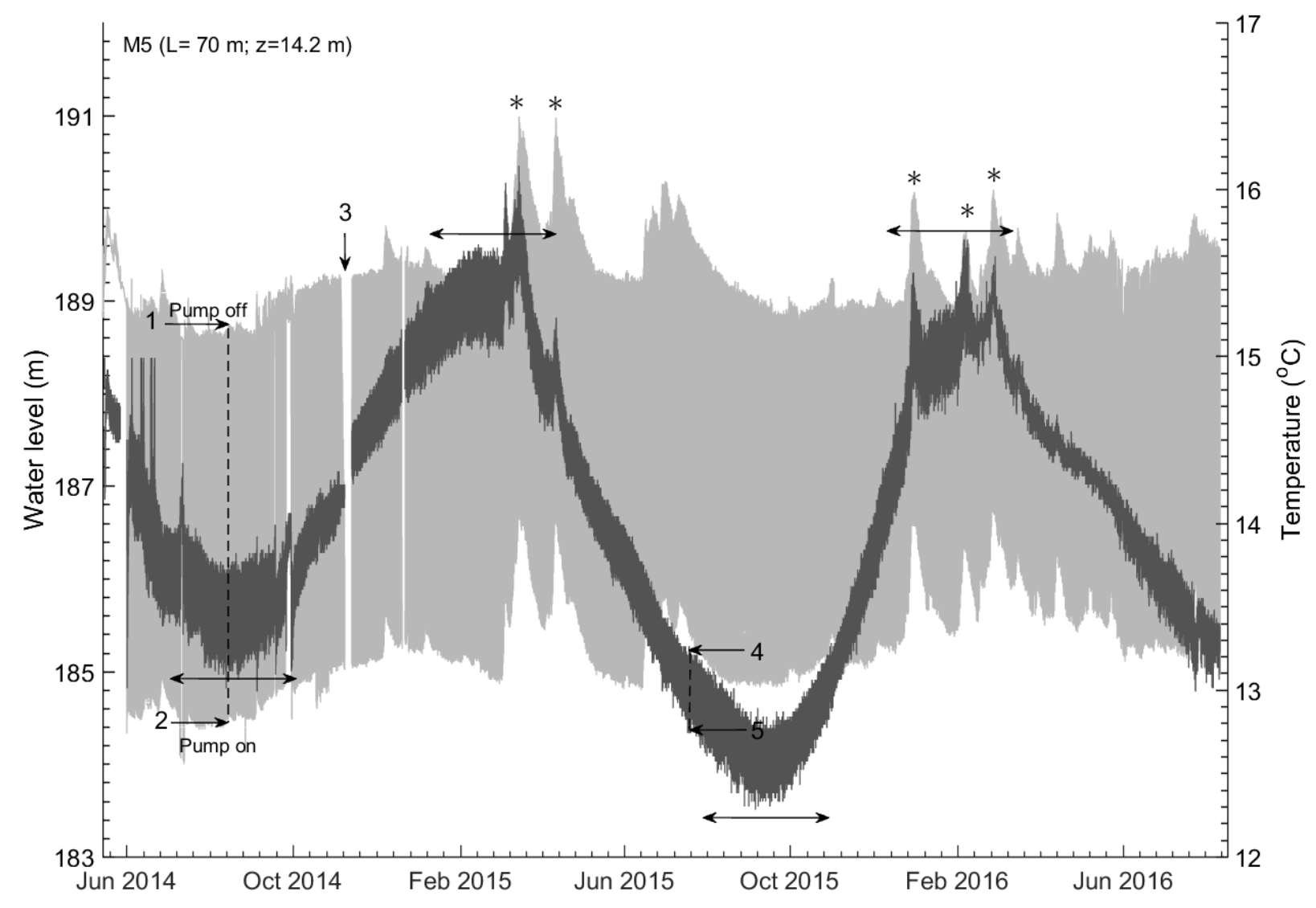

Figure 3.4 Temperature variations (dark grey) superimposed on seasonal fluctuations in water level (light grey) for well M5 between May 2014 and August 2016. Symbols and labels are explained in text. 
Temperature in this well showed an annual range of $3-4^{\circ} \mathrm{C}$ fluctuation with minima in July-October and maxima in February-April. This annual temperature range during nonpumping in summer and winter will be referred to as seasonal temperature shift (STS). At much briefer time scales, the temperature difference between pumping and non-pumping (i.e. the difference between Labels 4 and 5) will be referred to as pumping-induced temperature shifts (PITS). The longer-term STS range was approximately 7-20 times higher than PITS for well M5.

Figure 3.5 shows river water and air temperature between January 2014 and November 2016 for Montgomery pool and well G4, respectively. Air temperature was recorded at 1-minute intervals inside well G4 at $1.52 \mathrm{~m}$ below the surface and is a dampened measure of surface temperature. Both temperatures attained their maxima in August and minima in February, with an annual range of 28 and $20^{\circ} \mathrm{C}$, respectively. However, river temperature lagged behind that of air by approximately 15 days \pm 5 days. Both temperatures contain two different periodic components: i) a long term, seasonal trend and ii) a short term, diurnal trend. The second component complicates resampling the data to daily frequency, so, a visual rather than a numeric cross-correlation analysis was used to estimate $\tau$ between well and air temperatures. Stream temperature is less sensitive to diurnal temperature fluctuations than that of air, which shows diurnal spikes, especially during summer days and winter nights. The lower sensitivity of stream temperature to variations in solar and atmospheric radiation is ascribed to the higher specific capacity and volume of river water.

Figure 3.6 depicts high-resolution water-level (grey) and temperature (black) fluctuations at different seasons for well N4. This graphic is analogous to Figure 3.4, but for a different well and at much higher time resolution. PITS reached its maxima during summer (Figure 3.6a) and winter (Figure 3.6b) and its minima during spring and fall (not shown). The direction of PITS 


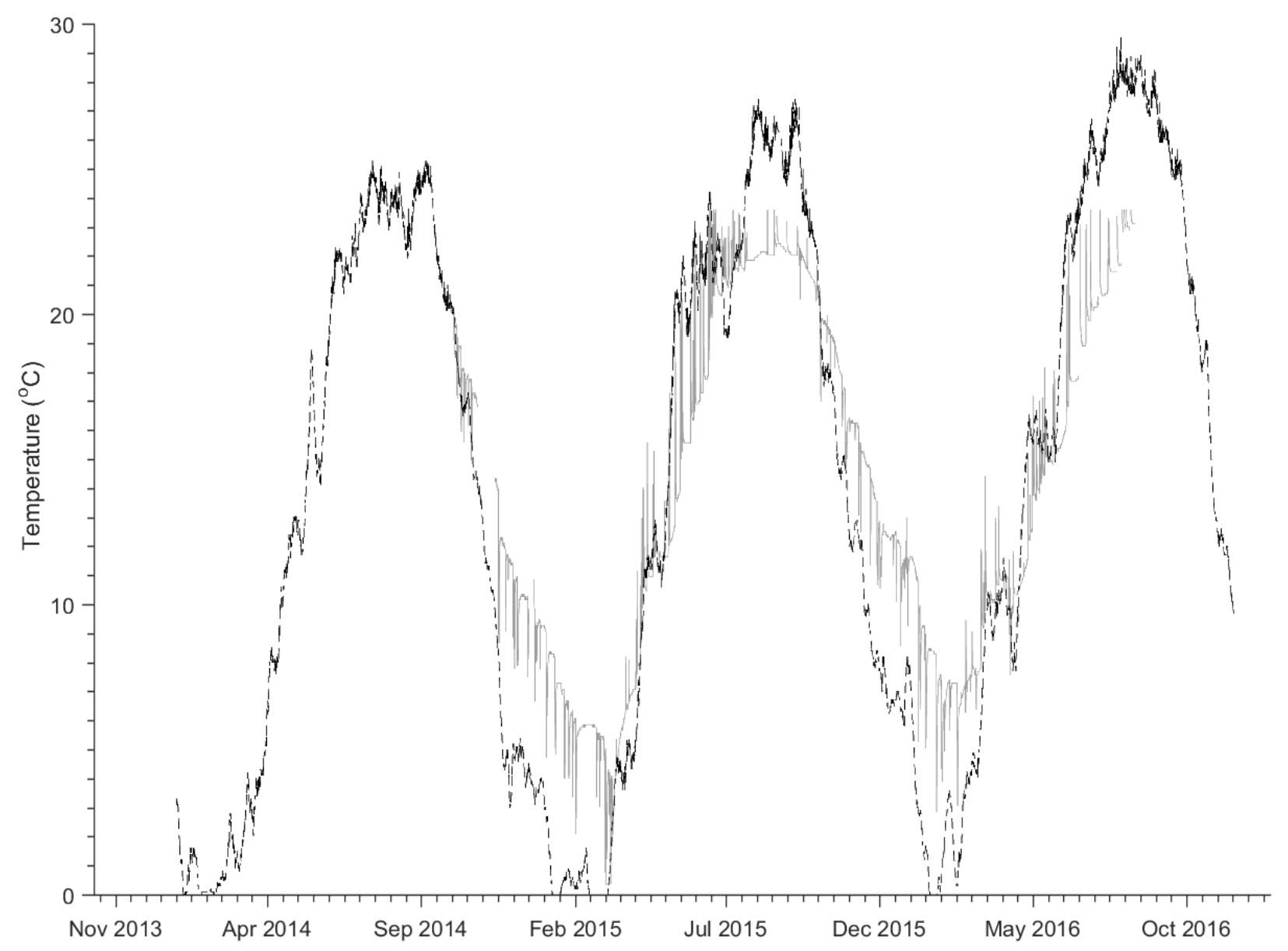

Figure 3.5 Seasonal oscillations of river temperature (dashed line) and air temperature (solid line) at well G4. 


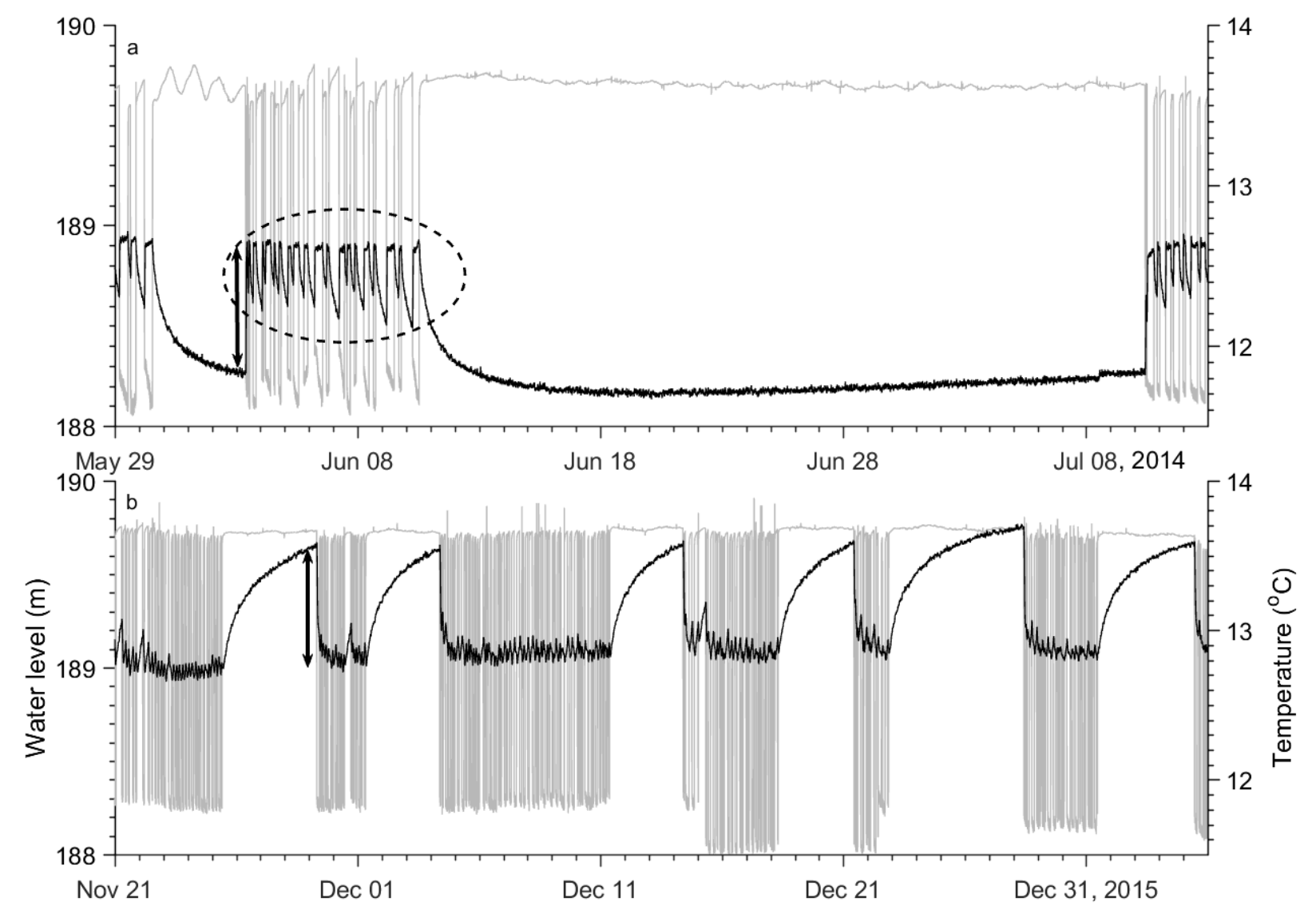

Figure 3.6 High-resolution PITS during (a) summer and (b) winter at well N4. Scale marks on the time-axes represent one day. 
differs in summer from winter. The PITS shift is negative (cools) during pump-off recovery in late spring-summer (negative re-equilibration), but warms in late fall-winter (positive reequilibration). Groundwater recovered to its non-pumping level in less than an hour but temperature took approximately a week to do so. Aquifer water level (top of the light-grey band) showed very little fluctuations, but temperature varied significantly, during the study periods.

PITS is represented by double-headed arrows in Figure 3.6 and reaches its peak within an hour of the onset of pumping because its temperature is derived from warmer groundwater entering the well from the basal gravel aquifer. Following cessation of pumping, temperature recovers to an ambient condition slowly and exponentially. The temperature fluctuations within the dashed oval are also PITS but related to high-frequency pumping. The longer the recovery period, the larger the PITS. However, the magnitude of the PITS is influenced more by season than by the duration of recovery period.

Figure 3.7 portrays temperature from Montgomery Pool (top) as well as water-level and temperature variations in wells N4 (middle) and N5 (bottom) at New Martinsville PWS between February 2014 and August 2016. The complementary grey stripes for the two wells indicate they were pumped in rotation. Stream and groundwater temperature ranged from 0 to $28^{\circ} \mathrm{C}$ and from 10.8 to $13.8^{\circ} \mathrm{C}$, respectively. STS (vertical double-headed arrows) varied slightly from one year to another for the same well (Figure 3.7a). Labels 1, 2, and 3 refer to the lowest temperatures in the stream, N4, and N5, respectively, indicating time lag between surface and groundwater temperature peaks. This time lag for well N4 is approximately 70 days shorter than N5, as indicated by Labels 2 and 3. STS (A) and PITS (C) for N4 are larger than that of N5 by $0.5^{\circ} \mathrm{C}$ and $0.3^{\circ} \mathrm{C}$, respectively. However, the results fall within the limit of uncertainty. These results can be ascribed to some combination of two factors: i) N4 being closer to the stream than N5 


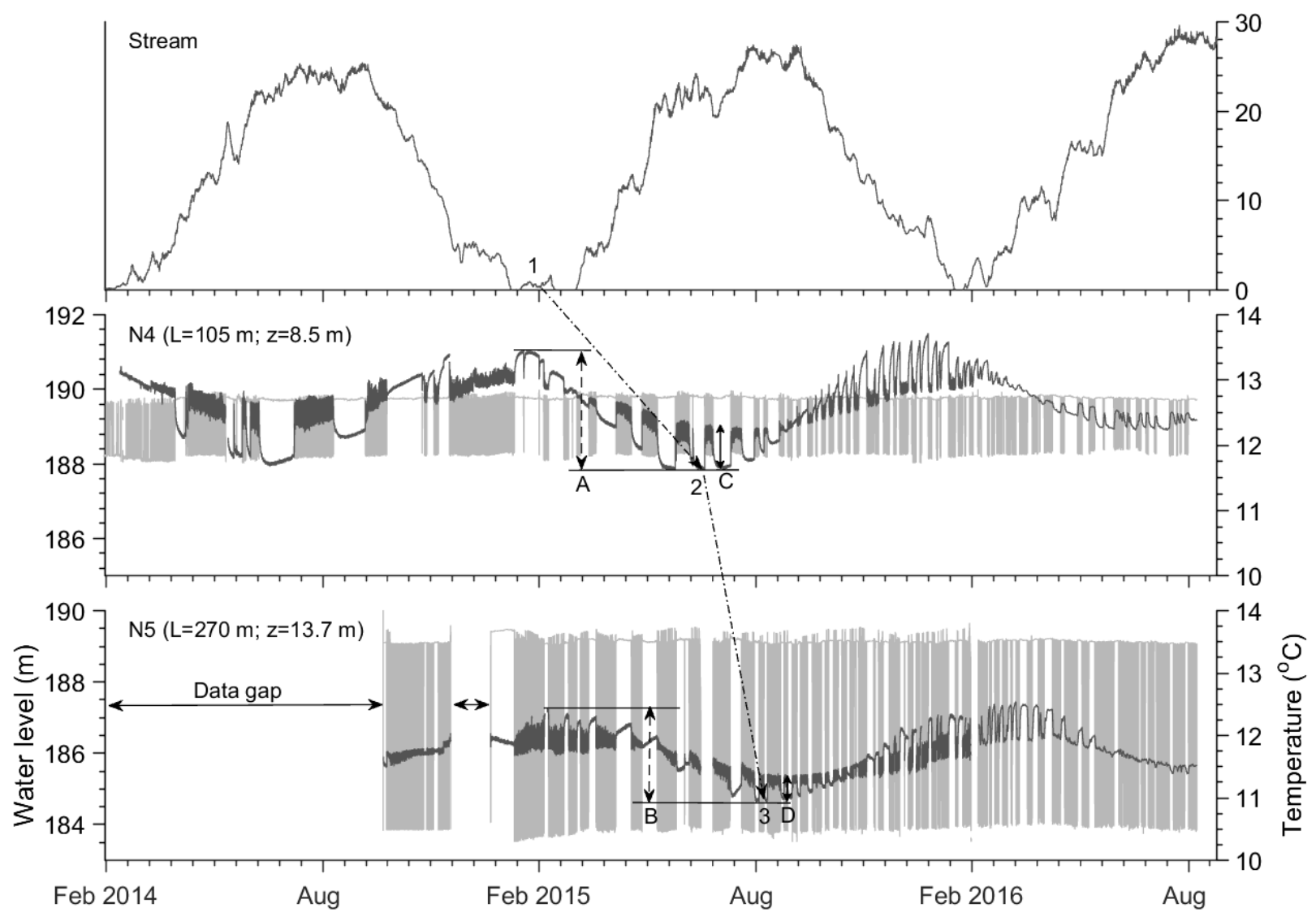

Figure 3.7 Stream temperature (top), water-level (grey), and temperature (black) fluctuations from February 2014 to August 2016 at wells N4 and N5, New Martinsville PWS. 
(105 vs $270 \mathrm{~m}$ ) and ii) the N4 sensor being closer to the surface than that of N5 (8.5 vs $13.7 \mathrm{~m}$ ). At all times shown, aquifer water level was higher and pumping drawdown lower for well N4 than N5, assumedly for the same reasons.

Figure 3.8 displays temperature only in the stream (top) and non-pumping wells (three bottom plots). The distance to the stream and sensor depths vary for the three wells. Consistently, stream temperature fluctuated more and had higher STS than that of groundwater. Stream temperature showed long-term periodic and seasonal but non-uniform oscillations. On the other hand, groundwater temperatures showed long-term periodic and seasonally-uniform oscillations that ranged between 12 and $16^{\circ} \mathrm{C}$, except for $\mathrm{G} 4$, which did not respond at all to surface temperature fluctuations. Solid and thin-dashed arrows indicate maximum and minimum temperature, respectively, in both surface and groundwater. The maximum summer stream temperature was $25^{\circ} \mathrm{C}$ in 2014 and $28^{\circ} \mathrm{C}$ in 2015 . The lagged summer temperature in wells G3 and G5 showed higher response in 2015 than in 2014 due to higher surface temperature in 2015. Temperature measured close to the surface (well G5) is visibly more responsive to surface temperature fluctuations than that measured at depth (well G3). The amplitude of STS decreased and $\tau$ increased in wells with deeper sensors. The distance to the stream for non-pumping wells showed no correlation with either $\tau$ or STS. Lag time ranged from 170 to 270 days for wells G3 and G5 and none was evident for well G4 for which temperature was uniform throughout the study period.

Figure 3.9 shows temperature fluctuations in the stream (top) and pumping wells at increasing distance from the river from February 2014 to August 2016. These pumps were operated concurrently at high frequency and their sensors were at depths from 11.7 to $17.5 \mathrm{~m}$ below surface. Double-headed arrows represent data gaps. Dashed lines indicate correlation of 


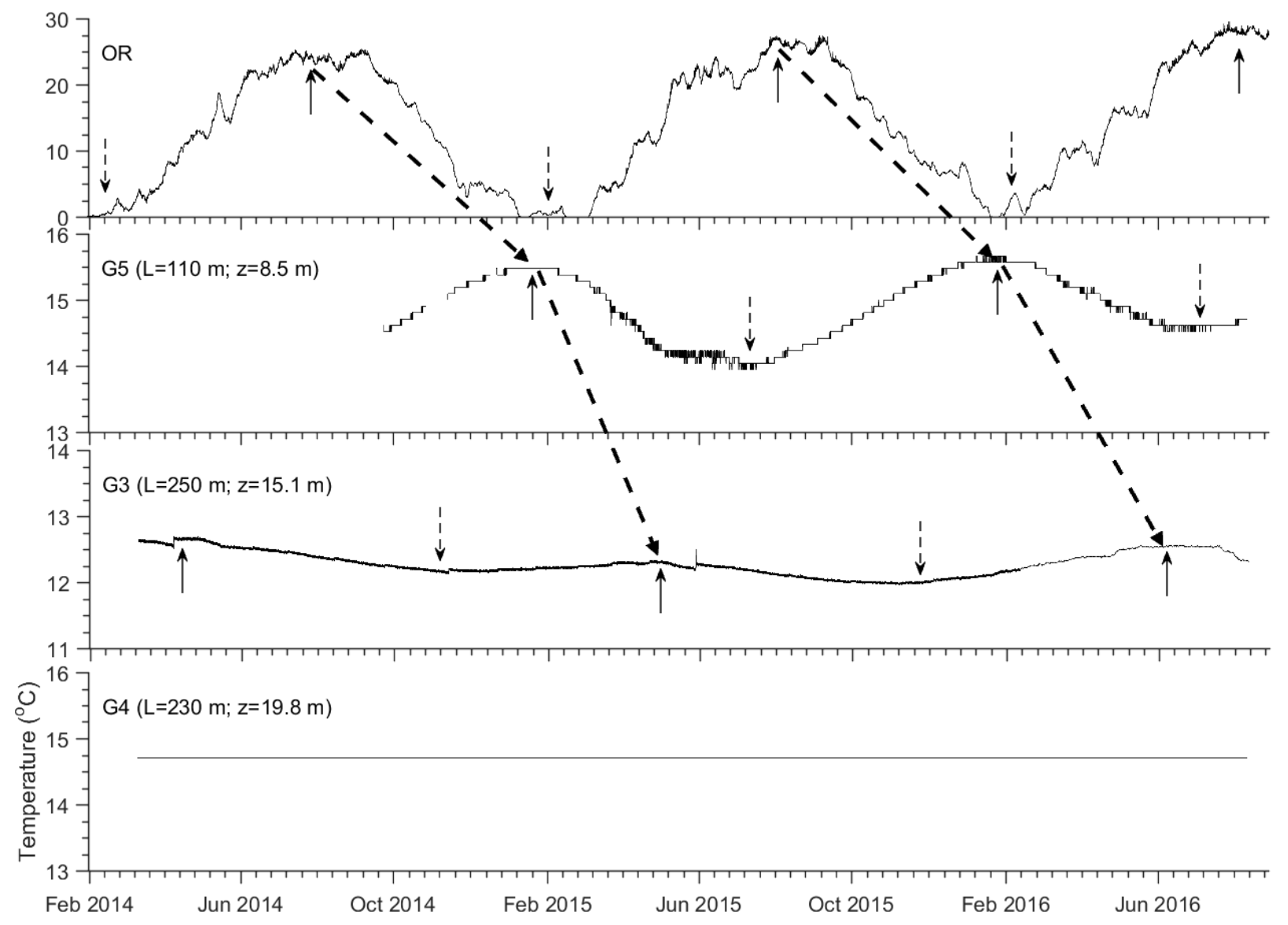

Figure 3.8 STS and $\tau$ for non-pumping wells at Glen Dale PWS. 


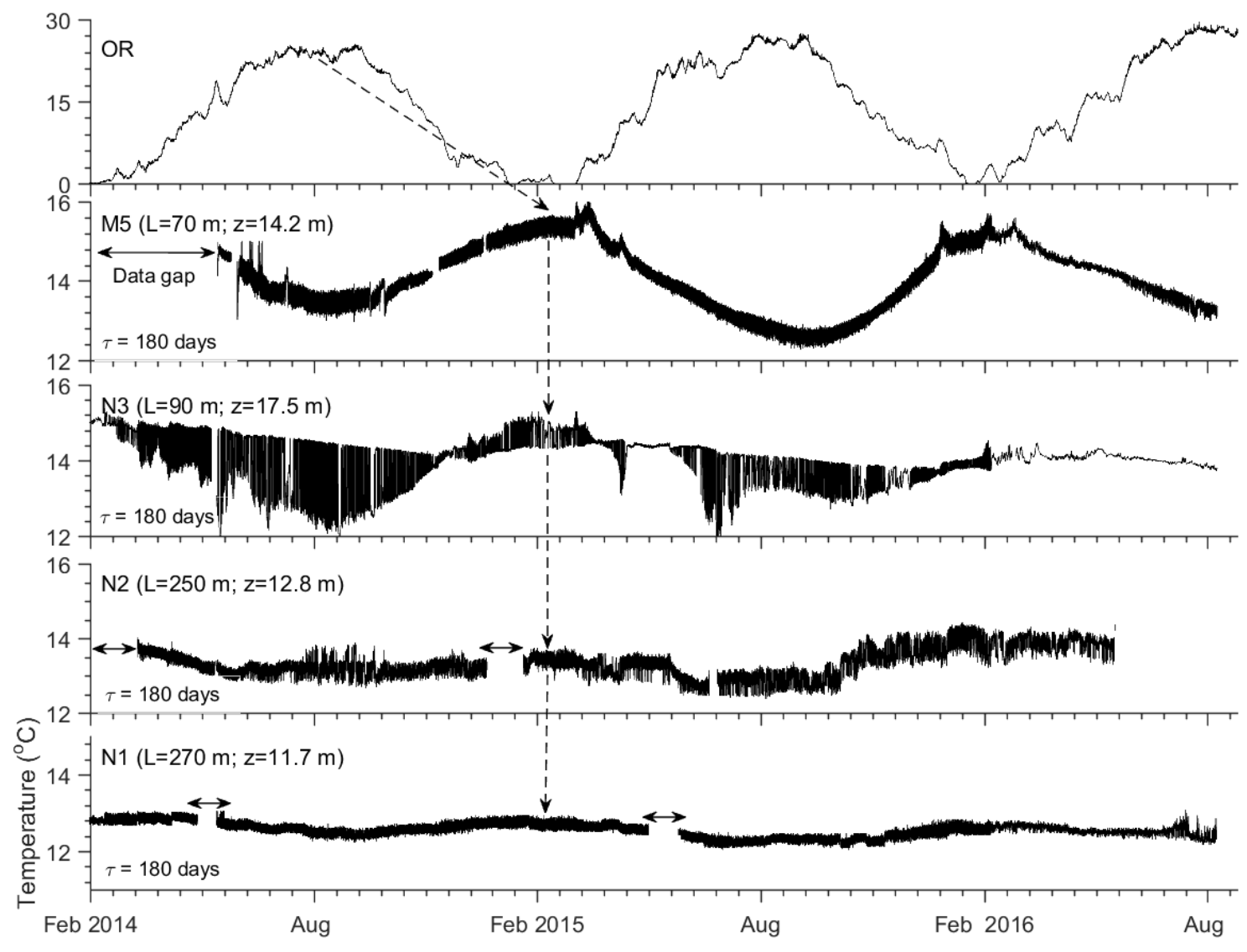

Figure 3.9 PITS, STS, and $\tau$ of pumping wells at increasing distance from the river, top (river) to bottom (most distant well). 
peaks for August 2015 maximum river temperature and the corresponding peaks in these wells. Groundwater temperature lagged behind that of the river by approximately six months. Seasonality is pronounced in M5 but less so in other wells. Annual STS ranges 0.9 to $3.8^{\circ} \mathrm{C}$ in these wells, decreasing with increasing distance from the river. Key observations for PITS in these wells include: a) they are highest for well N3 and temporally non-uniform, with some tendency to be highest in summer and lowest in spring and fall; b) PITSs for M5, N1, and N2 are more or less temporally uniform; and c) the magnitude of PITS shows slight correlation with sensor depth but no correlation with $\mathrm{L}$. The lag time is apparently insensitive to distance from the river. Short-term PITS show seasonal variation of amplitude in some wells but not others.

Figure 3.10 shows temperature fluctuations from February 2014 to August 2016 in the river (top) and pumping wells, ordered from top to bottom by increasing sensor depth below surface. These wells were operated at high frequency but in alternating rotation and exhibit both seasonal and short-term temperature fluctuations. Periods with no data represent data gaps (double-headed arrows). PITS is less at the times when wells are pumped at high frequency. Because of the rotational pumping, PITSs are prominent in those wells and relatively easy to identify compared to pumping wells in other PWS well fields. PITS are larger for wells with sensors at shallow depth and decrease with sensor depth. In summer 2015, PITS ranged from 0.2 to $0.7^{\circ} \mathrm{C}$ for these wells. Groundwater temperature lags behind that of the river by $140-215$ days (dashed lines). STS is also slightly larger for wells with sensors at shallow depths. On the other hand, lag time increases with sensor depth for these wells. Well distance to the river did not clearly correlate with either $\tau$, STS, or PITS. These results indicate that pumping-induced well temperature fluctuations are more sensitive to sensor depth than to distance from the river. 


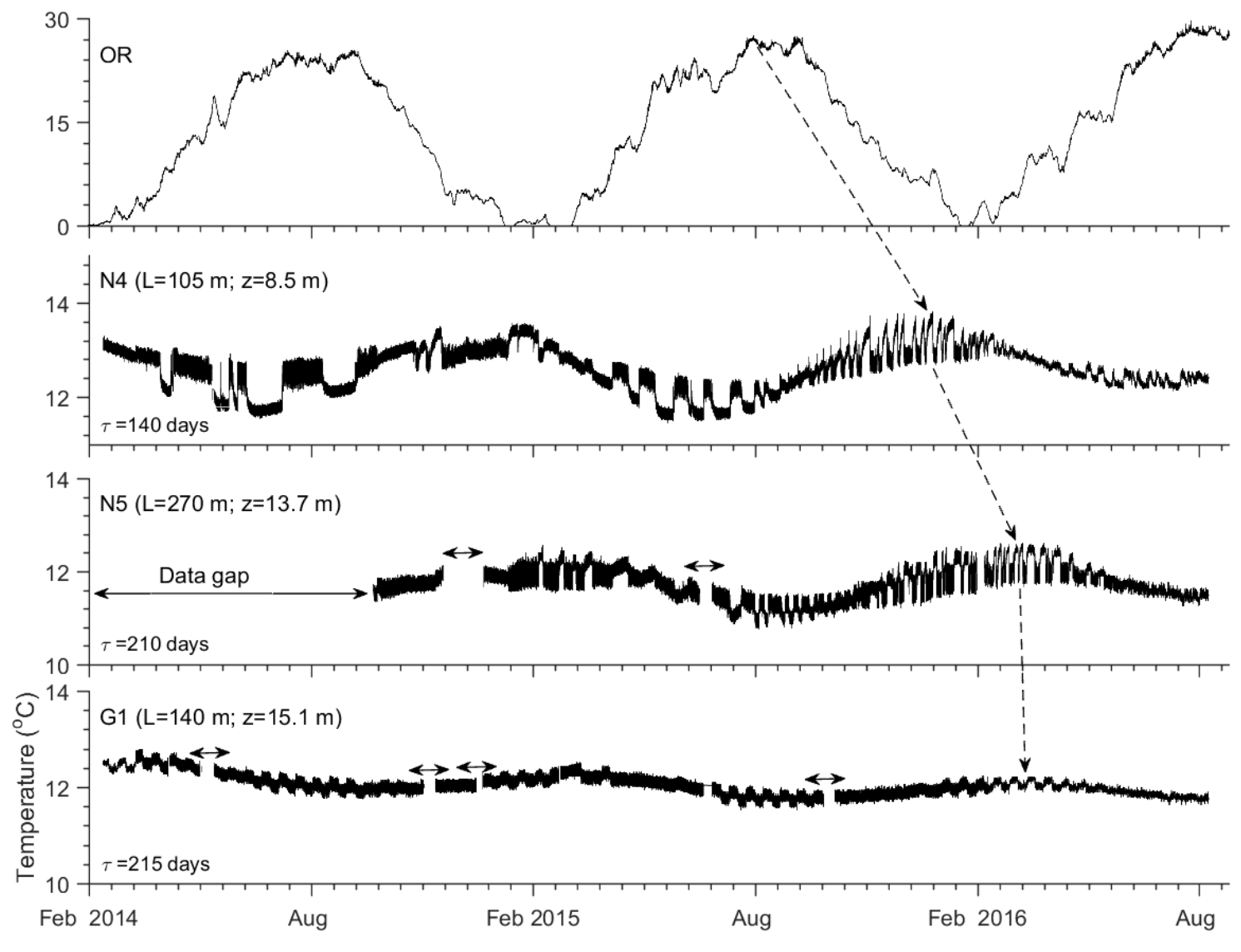

Figure 3.10 PITS, STS, and $\tau$ of pumping wells at increasing depth below the surface. 
Figure 3.11a depicts $\tau$ vs sensor depth for pumping and non-pumping wells, with lag times estimated by visual peak matching of summer 2015 river temperature to corresponding groundwater peaks (Figure 3.10). Only this one peak was correlated for each well because peaks at other times show similar lags within the limits of uncertainty. Lag times range from 140 to 270 days for these wells and were generally less for pumping than for non-pumping wells. Sensor depth and $\tau$ show some correlation $\left(\mathrm{R}^{2}=0.36\right)$ and indicate that $\tau$ generally increases with depth below the surface, with minor variability.

Figure 3.11b shows STS vs sensor depth for pumping and non-pumping wells, with STS calculated by subtracting summer-minimum from winter-maximum temperature in year 2015 , which ranged 0 to $3.8^{\circ} \mathrm{C}$. Like lag times, only one value was estimated for each well because STS estimated from other dates was close to uniform throughout the study period. These data indicate no clear relationship between the two parameters.

\subsection{Discussion}

Key observations in this dataset include:

1. Temperature inside pumping wells shows a 2-component signal with different values during pump on and pump off periods (difference=PITS),

2. Both components of temperature show strong seasonality with varying magnitudes of seasonal fluctuation from year to year (STS),

3. The peaks of both temperature components are shifted in time by $\tau$ with respect to those of surface temperature, and

4. The magnitudes of the PITS, STS, and $\tau$ can vary from well to well and, in the case of PITS, from season to season

Two-component temperature variations indicate pump on (temperature of produced water) and pump off (aquifer temperature outside the well casing at sensor depth) signals (Figure 3.4). PITS ranges from $0.2-2.5^{\circ} \mathrm{C}$ in different wells and at different times. The magnitude of 


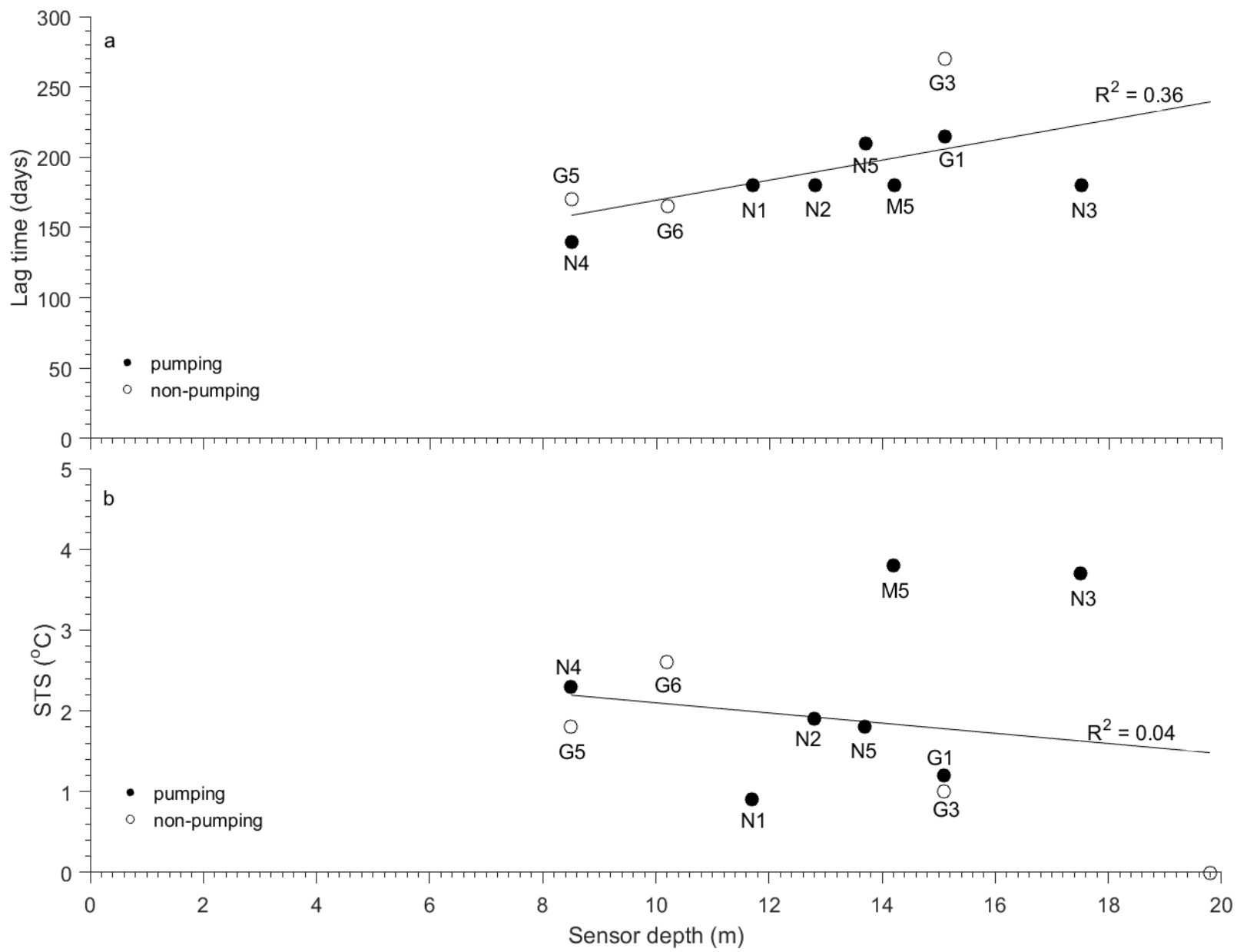

Figure 3.11 Lag time and STS vs sensor depth for pumping and non-pumping wells. Uncertainty in lag time and STS is approximately \pm 5 days and $\pm 0.5^{\circ} \mathrm{C}$, respectively. 
PITS tends to be high in summer and winter and low in spring and fall (Figure 3.6) due to the phase shift in the surface and groundwater temperatures. High-frequency intermittent pumping decreases PITS while at lower frequency, it increases (Figure 3.6). Several wells close to the river show higher PITS than those further away (Figure 3.7). These results suggest the amplitude of PITS depends on seasonality, pumping schedule, and L.

Both components of short-term temperature fluctuations show strong seasonality with an annual range $0-3.8^{\circ} \mathrm{C}$. In some cases, STS tends to decrease with sensor depth (Figure 3.10), but no consistent correlation was found when all samples are considered (Figure 3.11). In some cases, wells closer to the river display higher STS than ones farther away. These results suggest that heat transfer in these systems is complex and varies spatially.

The peaks of both temperature components shift with respect to surface temperature. The time lag of this shift ranges from 140-270 days. Lag time shows a weak positive correlation with depth for both pumping and non-pumping wells (Figure 3.11). For some wells, lag time was indifferent to change in L, z, or pumping rate (Figure 3.9 and Table 3.1), while for others, it correlates with z (Figures 3.8 and 3.10). Bartolino (2003) made similar observations in nonpumping wells at different depths in alluvial aquifers along the Rio Grande River. Stream temperature also lags behind surface temperature, though by far less than the time lag of groundwater (Figure 3.5).

The magnitudes of PITS, STS, $\tau$, and drawdown can vary from well to well and, in the case of PITS, from season to season due to the combined effects of L, z, and pumping rates. The magnitude and patterns of fluctuation in PITS, however, depend most strongly on both pumping scheme and season. Variations in pumping schedule are responsible for higher water demand during morning and evening times in a daily cycle. With respect to seasonality, summers show 
highest demand of water. Aquifer water level recovers to that of the aquifer quickly when the pump is turned off, but groundwater temperature responds much more slowly (Figures 3.4, 3.6, and 3.7). The magnitude of pumping drawdown was approximately uniform throughout the study period within each well, but the range of PITS varied both seasonally and with water demand.

These results and their interpretations are based on a limited number of observations (14 shallow wells). In such a small dataset, it was difficult to quantify relationships between either lag time or STS vs sensor depth (Figure 3.11). Heat flow in such shallow aquifers is complex as multiple sources of water to pumping wells could exist (vertical recharge, lateral seepage, and leakage from streambed and supply lines). Different combinations of L, z, and pumping rate could also substantially affect the magnitudes of PITS, STS, and lag time because based on the well distance and pumping rate, water budget could significantly vary (Jenkins, 1968). Despite the limitations, the variations of PITS demonstrate that stream exfiltration is a major source of water budget to a number of these pumping wells.

Surface-temperature fluctuations are large and rapid compared to those in the subsurface. Different thermal behavior between surface and subsurface makes these types of data potentially useful for identifying groundwater-surface water exchanges in hyporheic and bank storage contexts. The magnitude of PITS and lag time could provide clues as to source water and water budget for specific wells as higher PITS is linked to stream exfiltration. The technique offers potential to hydrogeologists and water operators interested in well-field management and sourcewater identification. 


\subsection{Conclusions}

Temperature and water level fluctuations in response to high-frequency intermittent pumping were observed from February 2014 to August 2016 in 14 shallow wells at three unconfined alluvial aquifers along the Ohio River. These observations indicate temperature inside pumping wells shows two different patterns i) STS (seasonal) and ii) PITS (pump on/off). In three non-pumping wells, only STS changes were observed. Groundwater temperature shows strong seasonality with different magnitudes of STS, PITS, and $\tau$ ranged between $0-3.8^{\circ} \mathrm{C}, 0.2-$ $2.5^{\circ} \mathrm{C}$, and 140-270 days, respectively. However, the magnitude and patterns of fluctuation can vary from well to well and, in the case of PITS, from season to season.

The magnitude and pattern of STS and $\tau$ variations are inconsistent between wells. STS tends to decrease with sensor depth, but not for all wells. Some wells closer to the river, but not all, have higher STS than ones more distant. Lag time shows correlation with z for some pumping wells and all non-pumping wells but no correlation with either $\mathrm{L}$, $\mathrm{z}$, or pumping rates in other wells. This inconsistency indicates that heat transfer in these systems is complex and varies spatially.

The magnitude of PITS showed gross agreement with i) inverse temperature distribution between surface and groundwater as well as ii) the distance to the stream. The difference between groundwater outside the casing and that produced by pumping (e.g., PITS) is highest during summer and winter and positive in winter, negative in summer. Wells closer to stream had larger PITS than those farther away. Therefore, stream exfiltration is a major source of water budget to a number of these pumping wells. Furthermore, it can be concluded that heat can used as a tracer in bank storage zone. 
Understanding of thermal behavior in shallow aquifers has potential to shed light on the connection between groundwater and surface water induced by pumping. Despite limited data and multiple potential sources of water to pumping wells (vertical recharge, lateral seepage, and leakage from streambed and supply lines), the PITS variations provide evidence that stream exfiltration occurs throughout the year in many pumping wells at different rates. However, this method would only be useful only when the contrast in temperature between groundwater and surface water is seasonally large, i.e. in summer and winter. 


\section{Numerical modeling of alluvial aquifer response to pumping under}

\section{fluctuating stream stage}

\section{Chapter Abstract}

Numerical simulation of aquifer response to pumping under fluctuating stream stage showed different flow patterns before and after well-field development. The aquifer water level always remained below stream stage near the well field. This modeling approach is subject to many uncertainties in parameter estimates nonetheless it shows the stream was losing at high flow and gaining at low flow during pre-development. During post-development, however, the stream was losing at high flow and gaining along some reaches and losing along others at low flow. Bank storage gains were limited to high stage, but stream exfiltration occurred year-round in response to pumping, which created a large cone of depression beneath the stream extending both upstream and downstream. The cone of depression was wider at low flow than at high flow. The model is most sensitive to variations in horizontal aquifer hydraulic conductivity and vertical streambed hydraulic conductivity, is least sensitive to variations in aquifer specific storage. 


\subsection{Introduction}

Groundwater is a primary source of drinking water and a potential source of exposure to pathogens that contribute to waterborne disease (USEPA, 2008; Hynds et al., 2014). The Centers for Disease Control and Prevention (CDC) identified that source-water contamination and inadequate treatment were major causes of groundwater-related outbreaks in the United States (Brunkard et al., 2011). The United States Environmental Protection Agency (USEPA) developed the Well Head Protection Program (WHPP) and the Source Water Assessment Program (SWAP) to protect groundwater from contamination and to maintain its quality under the Safe Drinking Water Act (USEPA, 1997; Kraemer et al., 2007).

Generally, public water supply (PWS) systems which use groundwater have limited hydrogeologic data beyond wells pumped for supply (Kozar and McCoy, 2004). It is common practice to plug unused wells to eliminate risk of groundwater contamination (USEPA, 1994). RK\&K (2002) conducted 26 SWAP studies for PWSs along the Ohio River Valley, of which only a few had observation wells. A numerical model of groundwater-surface water may be used in cases of limited hydrogeological data to understand system behavior (Wang and Anderson, 1982; Anderson and Woessner, 1991). CAPZONE (Bair et al., 1991), WHPA (Blandford and Huyakorn, 1993), WhAEM (Haitjema and Strack, 1994), CZAEM (Strack et al., 1994), and WhAEM2000 (Kraemer et al., 2007) are varieties of analytical and semi-analytical models have been developed to delineate source-water protection areas. Such relatively simple analytical models are generally incapable of incorporating heterogeneity and complex boundary conditions (Konikow and Bredehoeft, 1992; Springer and Bair, 1992). MODFLOW (McDonald and Harbaugh, 1988) is the most widely-utilized numerical flow modeling tool (Zhou and Li, 2011) and has also been applied to PWS wellfield problems. Groundwater flow models can produce 
represent information crucial for well-field management and expansion (Conrad and Beljin, 1996; Mercurio et al., 1999).

A number of states have completed many SWAP delineations using either the fixed radius, drawdown, or residence time methods (USEPA, 2004; Kraemer et al., 2007). These methods do not consider actual hydrogeologic boundary conditions and are somewhat arbitrary. As an example, the West Virginia Bureau of Public Health was mandated to delineate protection areas for all PWS systems in West Virginia. Many sites lacked substantive data for flow model development or calibration (Kozar and McCoy, 2004). Despite sparse data, numerical models were produced by Webb (2004) and Kozar and McMcoy (2004) to simulate steady-state groundwater flow for alluvial aquifers along the Ohio River. However, perfectly steady-state conditions rarely exist in nature, especially for alluvial aquifers with high-capacity pumping wells adjacent to streams. This study examines alluvial aquifer response to pumping under seasonally fluctuating stream stage. Its specific objectives are to i) portray groundwater levels during pre and post-development of well fields; ii) estimate the shape and areal extent of the pumping cone of depression during high- and low-flow periods; and iii) determine sensitivity of the groundwater model to variations in parameters.

The discontinuous alluvial gravel aquifer to be modeled is in the Town of McMechen on the east bank of the Ohio River, Marshall County, WV (Figure 4.1). McMechen PWS derives its supply from a well field in alluvium. The valley and its surrounding uplands have relief ranging from 85 to $175 \mathrm{~m}$. Hannibal Locks and Dam, located $45 \mathrm{~km}$ downstream, controls the pool elevation at McMechen at about 189.9 m. However, during storms, stream stage can quickly rise. McMechen Run and Jim Run are minor tributaries to the river. 


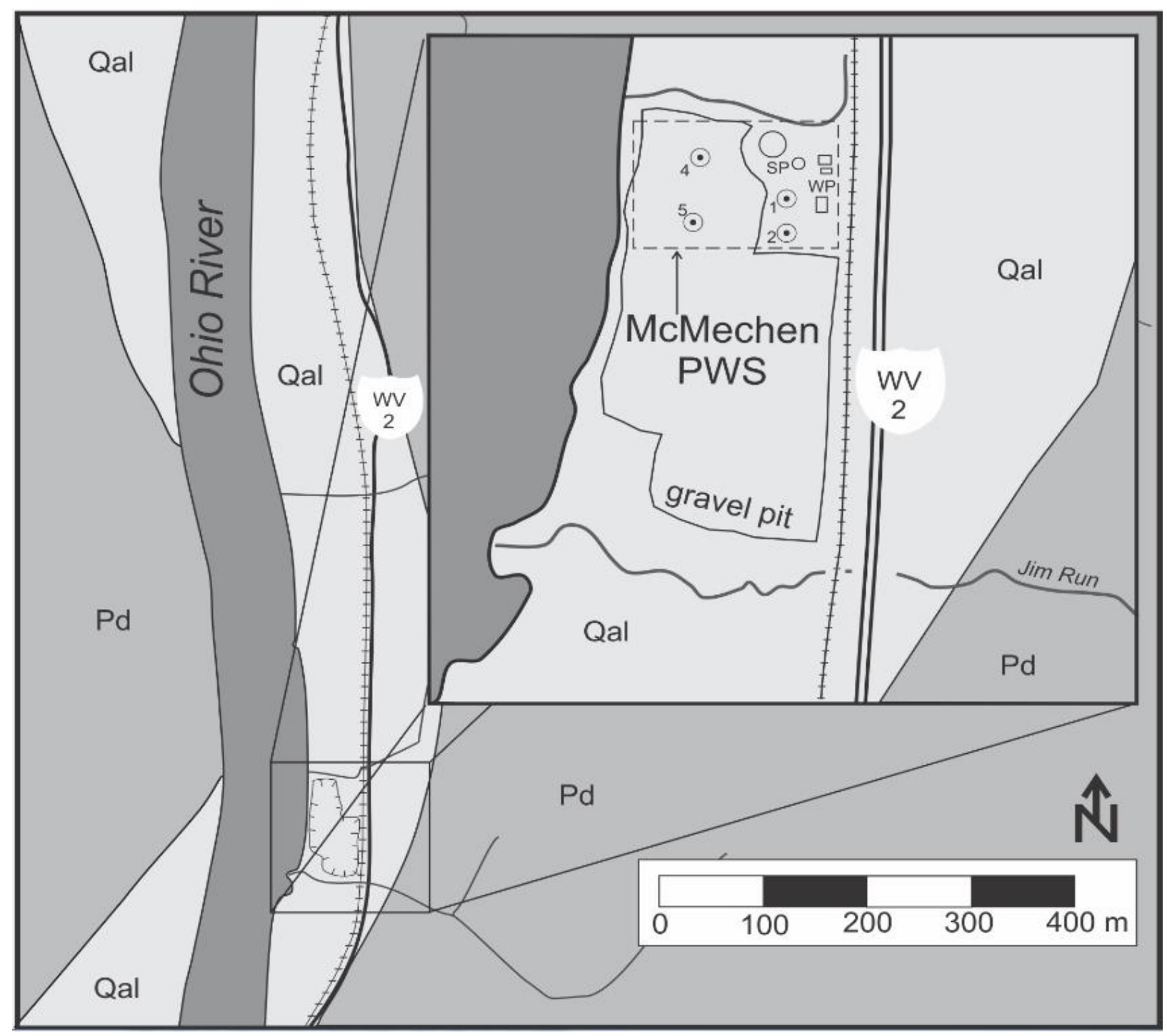

Figure 4.1 Site map of McMechen PWS showing pumping wells (numbered circles). Abbreviations: $\mathrm{Pd}=$ Permian Dunkard Group; Qal=Quaternary alluvium; $\mathrm{SP}=$ sewage plant (circles); WP=water treatment plant (rectangles) 
Bedrock of the Dunkard Group (Permian) is exposed along tributary banks and in the uplands (Figure 4.1). These nearly-horizontal rocks are composed of interbedded non-marine sandstone, siltstone, shale, limestone, and coal (Cross and Schemel, 1956). The Pleistocene-age Ohio River incised bedrock of Permo-Pennsylvanian age to form the modern valley (Prellwitz, 2004). Quaternary sediments in the valley are unconsolidated sand and gravel at the bottom, overlain by silt and clay (Carlston, 1962; Simard, 1989; Rogers, 1990). Quaternary-age terraces are $550 \mathrm{~m}$ wide in McMechen and composed of floodplain deposits, which also extend up the major tributaries.

The PWS withdraws groundwater intermittently and concurrently from 4 wells in two rows nearly parallel to the river. The wells are located 40 to $120 \mathrm{~m}$ apart and 70 to $160 \mathrm{~m}$ from the river. Wells M1 and M2 are farthest from (distal) and M4 and M5 closest to (proximal) the river. The wells were developed in basal sand and gravel of the alluvial aquifer, 20 to $21 \mathrm{~m}$ below land surface. The distal and proximal wells lie near the McMechen sewage treatment plant and a gravel pit, respectively. Per PWS staff, the pumping rates of these wells range from approximately 1,600 to $2,600 \mathrm{~m}^{3} /$ day (250 to $400 \mathrm{gal} / \mathrm{min}$ ). The static water level depths for wells M1, M2, and M5 are at 13, 13.2, and 8.4 m respectively. Table 4.1 summarizes the characteristics of wells within McMechen PWS.

\subsection{Method}

A four-layer concept was used to develop the flow model, employing vertical recharge, lateral seepage from upland areas to the east, and both vertical and lateral exfiltration from the stream as potential source waters for the PWS (Figure 4.2). Groundwater and surface water exchange through both the river bank (double-headed arrow) and streambed (triple-headed vertical arrows) (Figure 4.2). The nearly vertical river bank is composed of a thin layer of fine 
Table 4.1 Characteristics of wells from McMechen PWS

\begin{tabular}{|c|c|c|c|c|c|c|c|}
\hline PWS & $\begin{array}{c}\text { Well } \\
\text { ID }\end{array}$ & $\begin{array}{c}\text { Top of } \\
\text { casing (TOC) }\end{array}$ & $\begin{array}{l}\text { Average } \\
\text { pump rate }\end{array}$ & $\begin{array}{l}\text { Water level } \\
\text { below TOC }\end{array}$ & $\begin{array}{l}\text { saturated } \\
\text { thickness }\end{array}$ & $\begin{array}{l}\text { screen } \\
\text { length }\end{array}$ & $\begin{array}{l}\text { distance } \\
\text { from river }\end{array}$ \\
\hline \multirow{4}{*}{$\begin{array}{l}\frac{\tilde{D}}{U} \\
\sum_{0}^{e} \\
\sum\end{array}$} & M1 & 202.0 & 1,363 & 12.9 & 6.8 & 4.9 & 155 \\
\hline & M2 & 202.1 & 1,771 & 13.1 & 6.6 & 4.9 & 160 \\
\hline & M4 & 197.0 & 2,180 & - & - & 5.3 & 75 \\
\hline & M5 & 197.3 & 2,180 & 8.4 & 12.9 & 5.3 & 70 \\
\hline
\end{tabular}




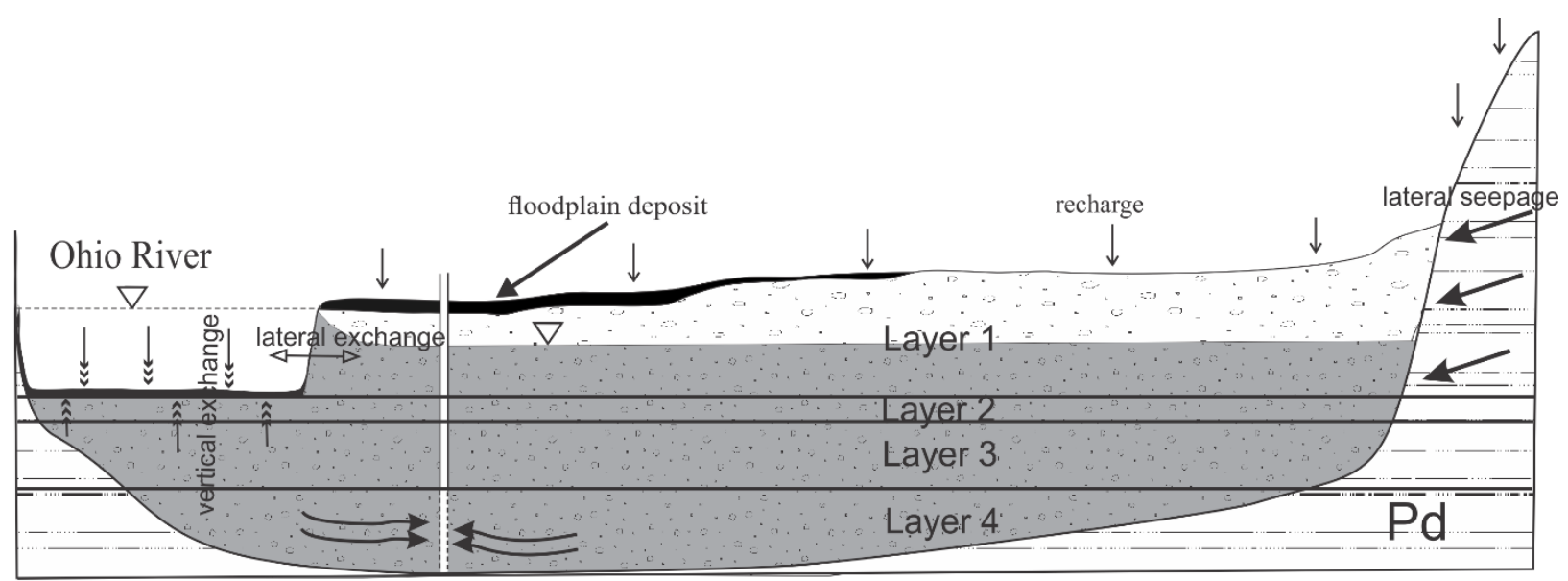

Vertical Exaggeration $=10 \mathrm{x}$

Figure 4.2 A representative cross-section of the Ohio River valley showing aquifer geometry, lithology, and water levels in both the river and aquifer. 
sediments. The recharge rate employed is spatially and temporally uniform. Pumping rates in the PWS wells are held constant for each well throughout the simulation when the wellfield was in use

\subsubsection{Water level measurements}

River-stage data for the Wheeling gaging station were compiled at 30-minute intervals from the U.S. Geological Survey database. Pressure transducers coupled with data loggers (vented Global Water® models WL-15 and WL-16) were used to collect fluid pressures in wells at one-minute intervals from February 2014 to August 2016. The pressure accuracy of WL-15 and WL-16 transducers are \pm 0.2 and $\pm 0.1 \%$ of full scale transducer range, respectively. The loggers were downloaded monthly and converted to heads above mean sea level using standard techniques (Weight and Sonderegger, 2001). Water column height above the sensor was measured periodically with an electric tape $( \pm 5 \mathrm{~mm})$ to verify transducer readings.

\subsubsection{Numerical Modeling}

Figure 4.3 shows the model layout of Layer 1 including well locations, tributary streams, inactive (no flow) cells, the Ohio River, the aquifer extent, and bedrock outcrop. The model contained 405 rows, 273 columns, and 4 layers covering $3.6 \mathrm{~km}^{2}$ of active cells. Row and column dimensions ranged from 2.5 to $12 \mathrm{~m}$ with highest resolution around pumping wells in all layers. The four layers were created to represent aquifer lithology and to simulate vertical flow (Figure 4.2). Land surface was interpolated from 30-meter DEMs. Layer 1 represents floodplain deposits and upgradient bedrock. Layers 2, 3, and 4 represent the sand and gravel aquifer at various depths. Layer 4 was identical in hydraulic conductivity to Layer 3 but is employed to represent the screened interval in pumping wells. 


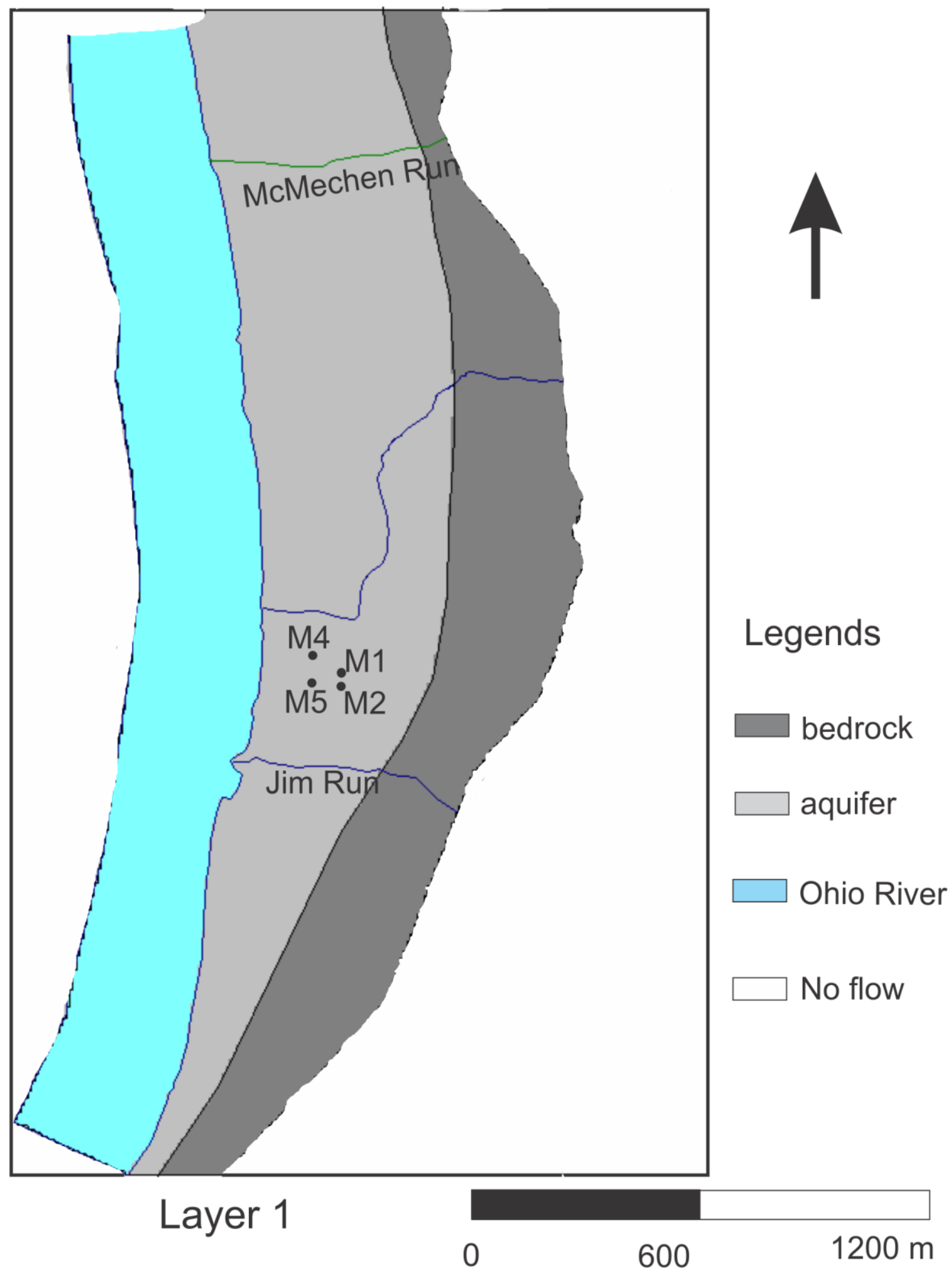

Figure 4.3 MODFLOW model showing well locations, bedrock, aquifer boundary, and no flow cells. The outline of the rectangle is limit of model grids. 
Recharge was parameterized using the $\mathrm{RCH}$ package at $0.22 \mathrm{~m} / \mathrm{yr}$ and evapotranspiration using the EVT package at $0.02 \mathrm{~m} /$ year with extinction depth $1 \mathrm{~m}$ (Kozar and Mathes, 2001). The west bank of the river and the bedrock ridge to the east of the alluvial valley were set as no-flow boundaries. The river was set as a constant-head (CHD) boundary.

In reality, Wells M1, M2, M4, and M5, are pumped concurrently and intermittently with breaks of variable duration, but simulated pumping was performed at equivalent average constant rates of $550,750,800$, and $900 \mathrm{~m}^{3} /$ day, respectively, somewhat less than the actual pump rates. The WEL package was used to simulate pumping from Layer 4, whose top and bottom elevations correspond to the well screen intervals. The DRN package was employed to simulate baseflow into tributary streams at locations where aquifer heads are higher than the DRN-specified heads, set to match the top elevation of Layer 1.

\subsubsection{Model calibration and simulations}

Values of $K_{h}, K_{v}, S_{s}$, and specific yield from previous studies along the Ohio River valley (Table 4.3) were averaged and used as initial estimates for this model. The aquifer was treated as homogeneous but anisotropic $\left(\mathrm{K}_{\mathrm{h}} / \mathrm{K}_{\mathrm{v}}=10: 1\right)$. Layer 1 was treated as unconfined (LAYCON=1) and deeper layers as confined (LAYCON=0). The PCG2 solver was employed using a maximum head change of $10^{-4} \mathrm{~m}$ for model convergence. Flow between layers was solved using vertical inter block conductance.

The model was solved to a steady-state condition to set up initial heads for transient simulation during a 10-day long storm in December 2014, Time was discretized using 41 stress periods and 121 time steps. Aquifer hydraulic conductivity and storage were varied to match simulated to observed heads for wells M1 and M5, minimizing SSE (sum of squared errors) and 
RMSE (root-mean-square error) values. Model mass balance was used to estimate the amounts of baseflow, induced infiltration, and bank storage at both low and high stream stages.

Although the river is regulated, stream stage fluctuates in response to precipitation events. Stream stage is lowest during summer and fall and higher during the rest of the year. The model was simulated for both low and high flow, e.g. summer and spring flow conditions. Stream stages of 192 and $190.2 \mathrm{~m}$ were employed for high and low flow, respectively. Stream had zero gradient, like a lake, during pre- and post-development.

\subsection{Results}

Figure 4.4 depicts observed (solid) and simulated (dashed) water levels in the stream (top) and wells M1 and M5 for the calibration period. The simulated and observed heads for these wells are similar. The proximal well (M5) shows more abrupt response to stream-stage fluctuations than the distal well (M1). The residuals (i.e., observed minus simulated head) ranged from -0.04 to $0.12 \mathrm{~m}$ and are slightly higher for well M5. The calibrated model parameters (Table 4.2) are comparable to those from previous studies (Table 4.3).

Figure 4.5 shows groundwater flow paths and color floods of hydraulic heads in Layer 1 for pre-development (left) and post-development (right) scenarios. During predevelopment, the stream was losing during high flow and gaining during low flow over the entire reach. All flow lines are approximately perpendicular to the stream bank. During post-development, aquifer head in the vicinity of the well field is below stream stage and gains water from the stream throughout the year. However, an upstream reach of the river still gains water during low flow, but not high flow. Stream exfiltration is lower in flux at low stage than at high stage (Table 4.4). These 

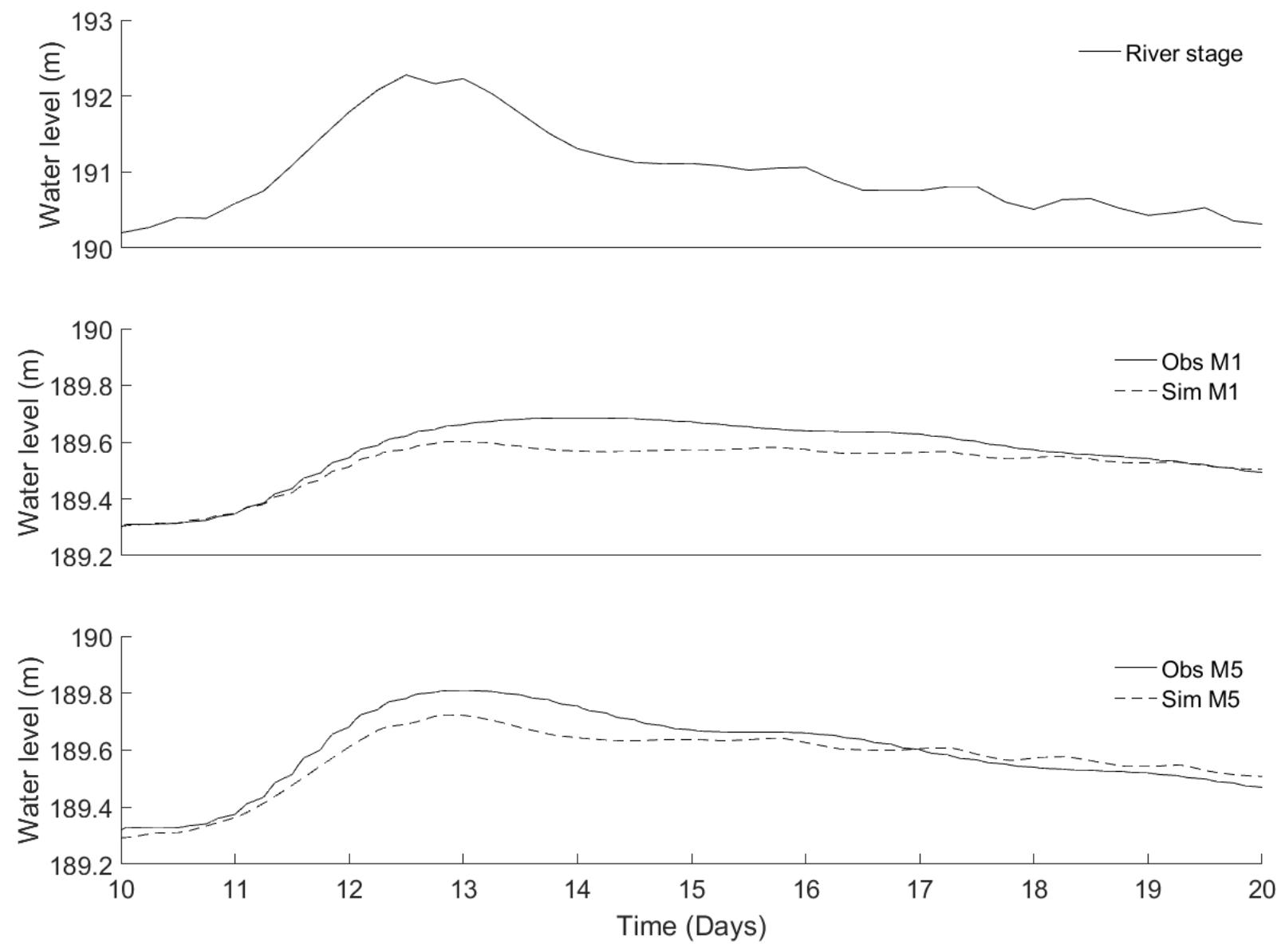

Figure 4.4 Observed and simulated water level in the wells M1 and M5 in response to a 10-day stream hydrograph observed in December 2014 (Top). 
Table 4.2 Parameter estimation for the calibrated model

\begin{tabular}{|l|l|l|l|l|}
\hline Parameters & Riverbed sediment (1) & Floodplain (2) & Sand and gravel (3) & Bedrock (4) \\
\hline $\mathrm{K}_{\mathrm{h}}$ & 0.49 & 9.17 & $197^{*}$ & 3 \\
\hline $\mathrm{K}_{\mathrm{v}}$ & 0.02 & 0.14 & 35 & 0.6 \\
\hline $\mathrm{S}_{\mathrm{s}}$ & $2.5 \times 10^{-5}$ & $0.15^{* *}$ & $1.6 \times 10^{-4}$ & $4.5 \times 10^{-3}$ \\
\hline
\end{tabular}

*average, ${ }^{* *}$ specific yield 
Table 4.3 Comparison of calibrated aquifer parameters with those from previous hydrogeological studies along the Ohio River

\begin{tabular}{|l|l|l|}
\hline Authors & Aquifer $\mathrm{K}_{\mathrm{h}}(\mathrm{m} /$ day $)$ & Streambed $\mathrm{K}_{\mathrm{h}}(\mathrm{m} /$ day $)$ \\
\hline This study & 197 & 0.49 \\
\hline Unthank, 2013 & 100 & 0.2 \\
\hline Kozar and McCoy, 2004 & 150 & 0.3 \\
\hline RK\&K, 2002 & 122 & -- \\
\hline
\end{tabular}




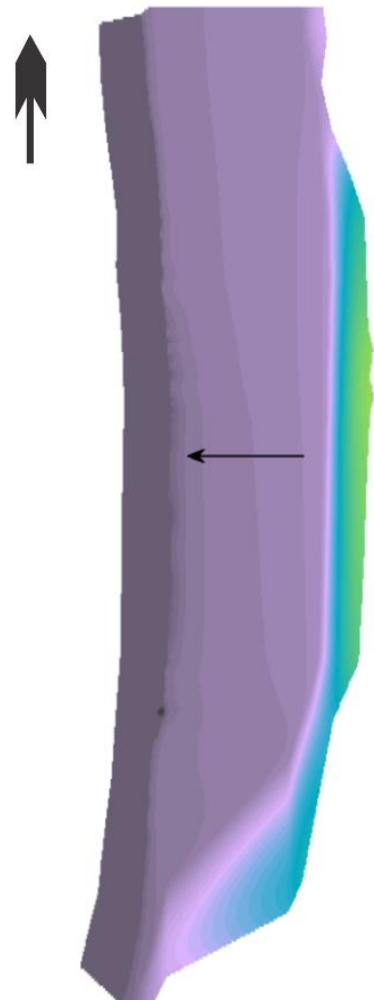

Low flow

Pre-development

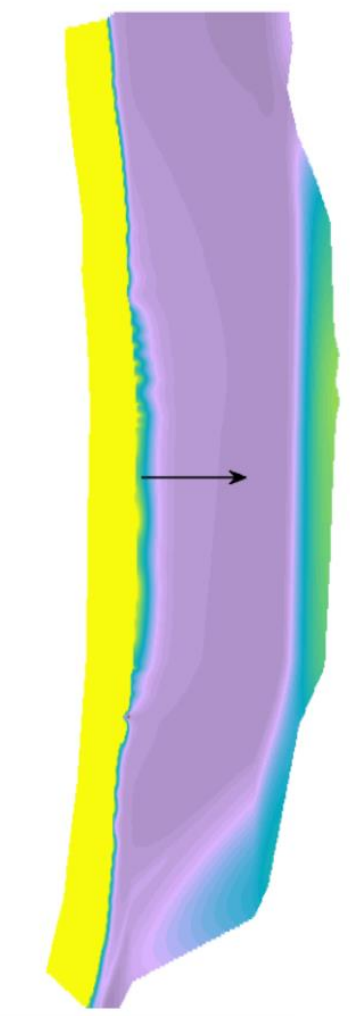

High flow

Pre-development

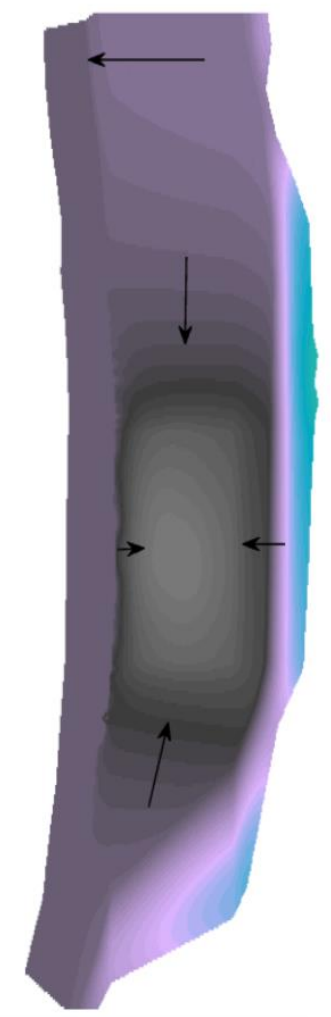

Low flow

Post-development

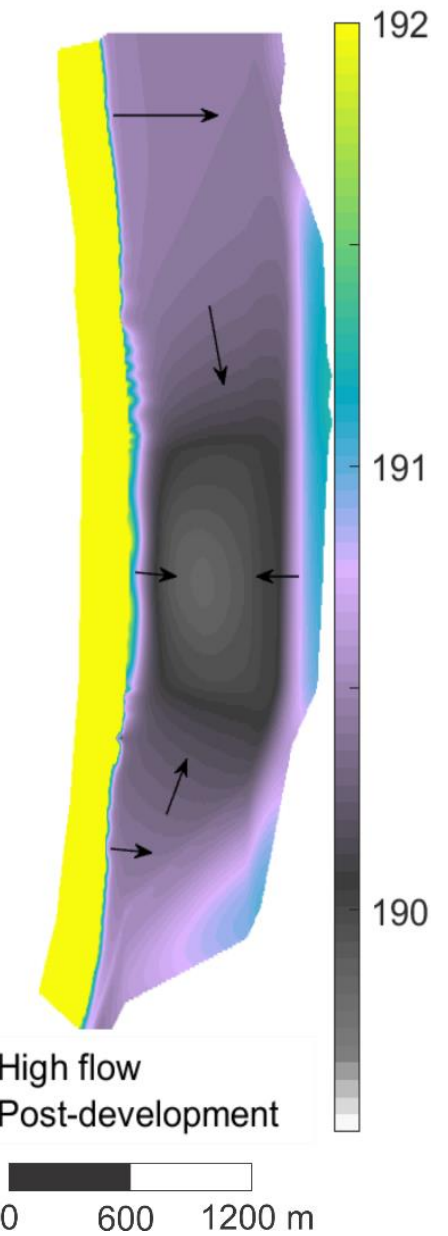

190

Figure 4.5 Groundwater flow paths (arrow head directions) during low and high stream stages at pre- and post-development of well field. The color bar on the right side of the figure represents head above mean sea level. Arrows indicate groundwater-flow directions. 
Table 4.4 Induced infiltration, bank storage, and baseflow values derived from MODFLOW mass balance.

\begin{tabular}{|c|l|l|l|l|l|}
\hline Parameter & values & \multicolumn{2}{|l|}{ Low flow $\left(\mathrm{m}^{3} /\right.$ day $)$} & \multicolumn{2}{l|}{ High flow $\left(\mathrm{m}^{3} /\right.$ day $)$} \\
\cline { 3 - 6 } & & $\begin{array}{l}\text { Induced } \\
\text { infiltration }\end{array}$ & Baseflow & Bank & Baseflow \\
ctarase & \\
\hline Base values & Calibrated & 287 & 2,151 & 22,012 & 0 \\
\hline \multirow{2}{*}{$\mathrm{K}_{\mathrm{h}}(\mathrm{m} /$ day $)$} & 100 & 631 & 2,220 & 19,565 & 0 \\
\cline { 2 - 6 } & 400 & 37 & 2,572 & 26,683 & 0 \\
\hline \multirow{2}{*}{$\mathrm{K}_{\mathrm{v}}(\mathrm{m} /$ day $)$} & 0.0002 & 490 & 249 & 10,844 & 0 \\
\cline { 2 - 6 } & 2 & 376 & 9,710 & 45,762 & 0 \\
\hline \multirow{3}{*}{$\mathrm{S}_{\mathrm{s}}$} & $1.6 \times 10^{-6}$ & 290 & 2,128 & 21,900 & 0 \\
\cline { 2 - 6 } & 0.016 & 298 & 2,173 & 31,155 & 0 \\
\hline \multirow{3}{*}{$\mathrm{C}\left(\mathrm{m}^{3} /\right.$ day $)$} & 0 & 26 & 4,837 & 15,633 & 0 \\
\cline { 2 - 6 } & 1,500 & 35 & 3,375 & 20,475 & 0 \\
\cline { 2 - 6 } & 6,000 & 2,054 & 970 & 25,079 & 0 \\
\cline { 2 - 6 } & 9,000 & 4,434 & 394 & 28,175 & 0 \\
\hline
\end{tabular}


simulations indicate an extensive cone of depression within the aquifer extending beneath the river, wider at low flow than at high flow.

Figures 4.6 and 4.7 show color floods of hydraulic head and the shape and extent of the cones of depression in Layer 2 for a variety ofaquifer parameters at both low and high stream stage. The cones of depression are deeper and wider at low stream stage than at high stream stage for corresponding parameters. The cones of depression extend from $720 \mathrm{~m}$ for $100 \mathrm{~K}_{\mathrm{v}}$ to $2,200 \mathrm{~m}$ for $2 \mathrm{Q}$ during low flow and almost none for $100 \mathrm{~K}_{\mathrm{v}}$ to $1,900 \mathrm{~m}$ for $2 \mathrm{Q}$ during high flow. The head gradient between the streamand wells steepens with increasing pumping rate at both low and high stage.

During low flow, high values of aquifer and streambed hydraulic conductivity induce less steam exfiltration and generate more baseflow (Table 4.4). Conversely, higher pumping rates induce more stream exfiltration and generate less baseflow. Mass balance results rare similar for variations in $\mathrm{S}_{\mathrm{s}}$. The stream exfiltrates up to $4,400 \mathrm{~m}^{3} /$ day due to pumping (Table 4.4). Both upstream and downstream reaches gain water as baseflow in all simulations but at different rates.

During high flow, stream stage is much higher than the aquifer water level and the entire reach loses water to the aquifer. Stream losses are nearly two orders of magnitude higher than at low flow (Table 4.4). The aquifer storage increases from 11,000 to $45,000 \mathrm{~m}^{3} /$ day for the simulations of streambed $\mathrm{K}_{\mathrm{v}}$ at 0.0002 and $2 \mathrm{~m} /$ day.

\subsection{Discussion and conclusion}

Alluvial aquifer response to pumping under fluctuating stream stage was studied using a numerical model. Simulated and observed water levels matched for wells M1 and M5 during a 


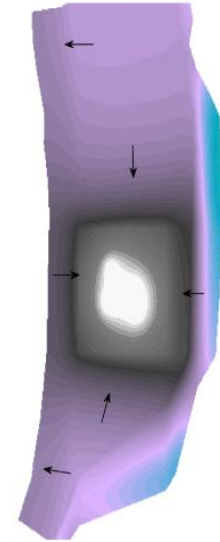

$0.5 \mathrm{~K}_{\mathrm{n}}$

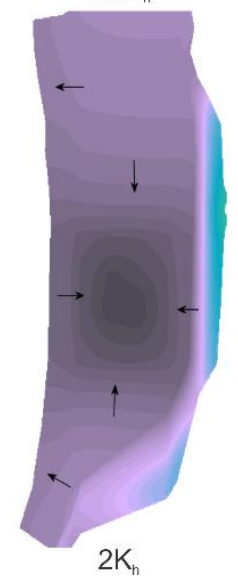

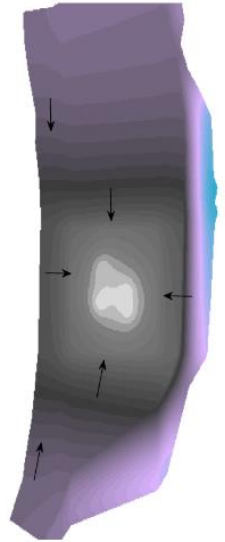

$0.01 \mathrm{~K}$

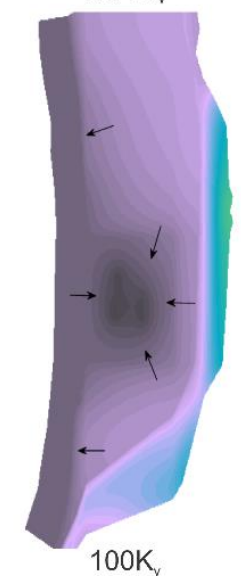

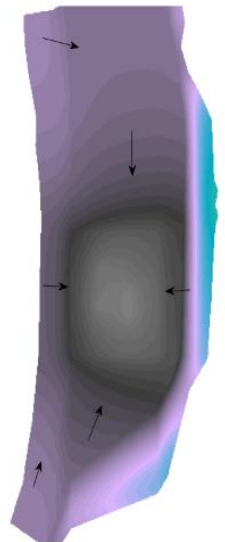

$0.01 S_{s}$

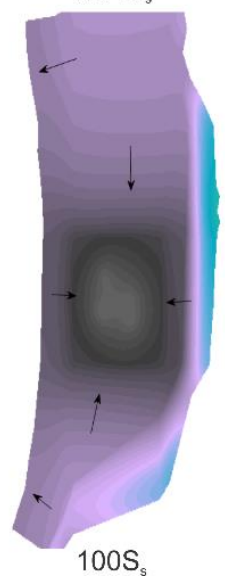

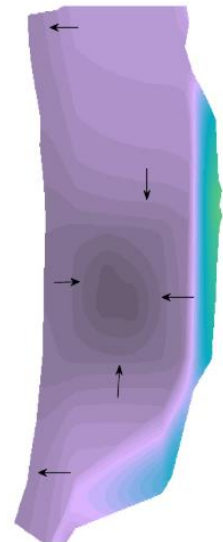

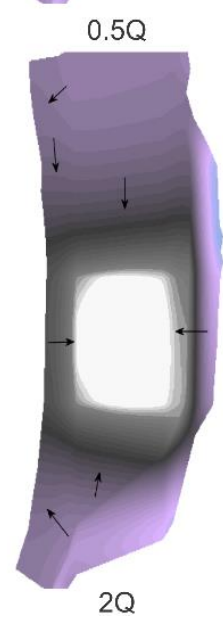

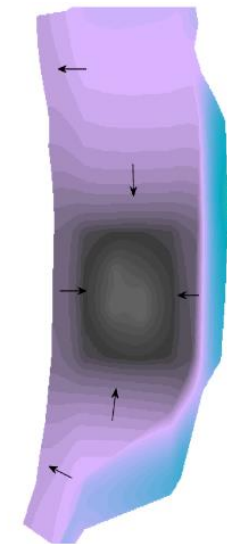

Calibrated

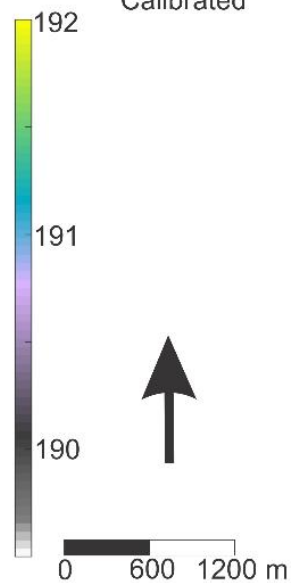

Figure 4.6 The shape and extent of the cone of depression in response to changes in aquifer parameters at low stream stage. Arrow heads indicate the direction of groundwater flow. 


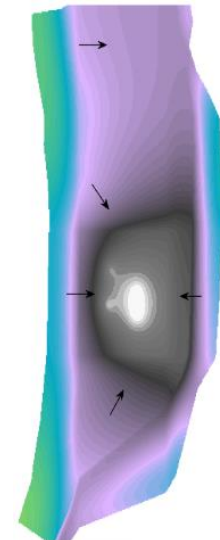

$0.5 \mathrm{~K}_{\mathrm{h}}$

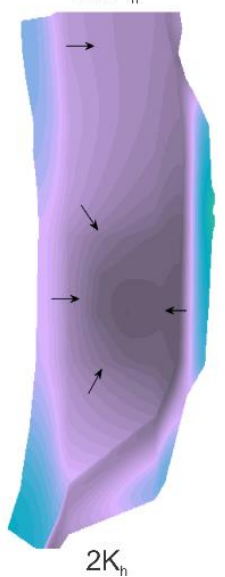

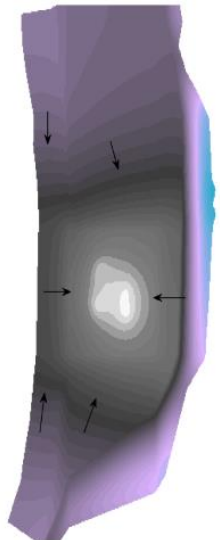

$0.01 \mathrm{~K}$

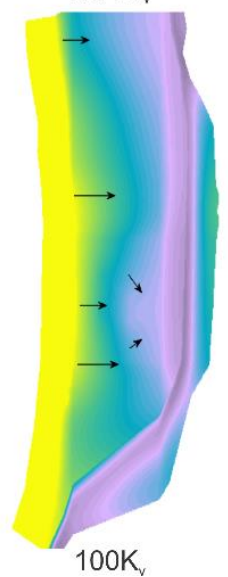

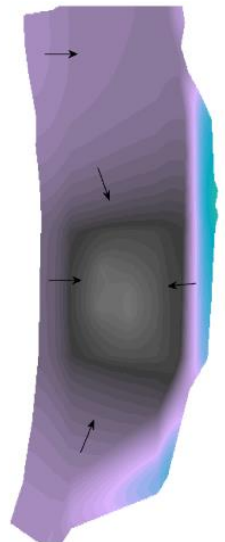

$0.01 \mathrm{~S}_{\mathrm{s}}$

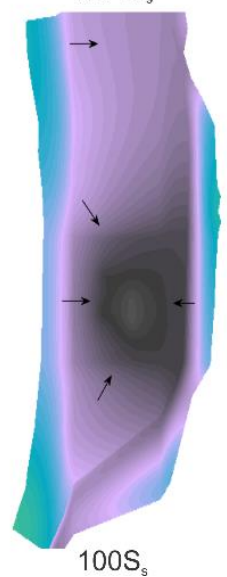

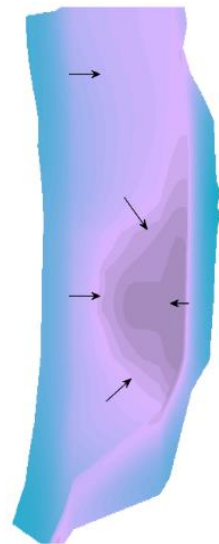

$0.5 \mathrm{Q}$

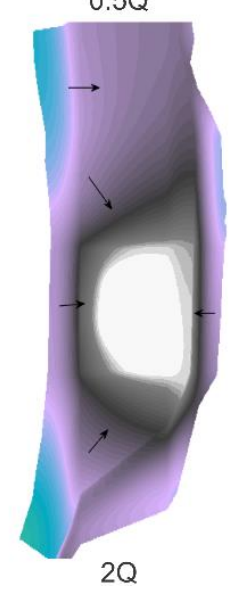

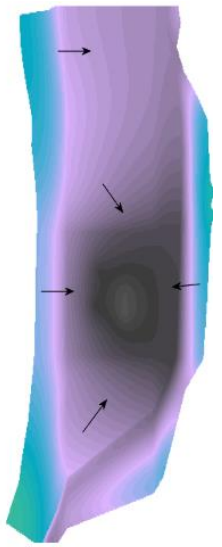

Calibrated

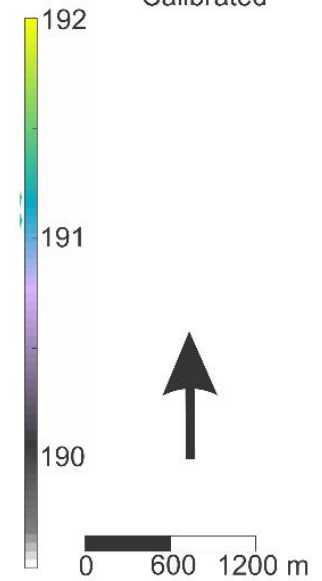

Figure 4.7 The shape and extent of the cone of depression in response to changes in aquifer parameters at high stream stage. Arrow heads indicate the direction of groundwater flow. 
10-day transient period. The wells close to the stream respond to stream-stage fluctuation more quickly and to greater amplitude than the distal wells. For one set of model parameters, simulated heads failed to match the observed ones, suggesting the aquifer may be heterogeneous. This result is consistent with the findings for other aquifers along the Ohio River (RK\&k, 2002; Maharjan and Donovan, 2016).

Key observations made during low flow include: i) the entire reach gains water during predevelopment (Figure 4.5), ii) some reaches gain and other reaches lose water to the aquifer during post-development (Figures 4.6 and 4.7), iii) the extent of the cones of depression is larger in size (Figures 4.6 and 4.7), and iv) the stream reaches gain more water than they lose (Table 4.4). Pumping clearly induces surface water and changes groundwater flow paths.

Similarly, key observations for high flow include: i) the entire reach loses water at preand post-development (Figures 4.5-4.7), ii) the cones of depression are less extensive (Figures 4.6 and 4.7), and iii) the rate of stream exfiltration is much greater than the induced-infiltration rate, indicating gains in bank flow storage (Table 4.4).

The mass balance results show pumping-induced stream exfiltration rates from 35 to $4,400 \mathrm{~m}^{3} /$ day at low stage (Table 4.4). At the calibrated value, stream exfiltration contributed $300 \mathrm{~m}^{3} /$ day, $10 \%$ of the daily pumping rate. RK\&K (2002) estimated the river contributes 60 to $70 \%$ of daily pumping (approximately $9,300 \mathrm{~m}^{3} /$ day) to the PWS wells, which corresponds to higher pumping rate.

Modeling results suggest that the exchange of water between aquifer and stream varies temporally and spatially. Model results are most sensitive to $K_{h}$ and $K_{v}$ and least sensitive to $S_{s}$. Stream stage influences the magnitude of bank storage during high flow, while pumping 
determines stream exfiltration rate during low stage. The model parameter values are slightly higher and stream exfiltration is lower than that of the previous studies along the Ohio River.

The results are based on a simplified numerical model compared to nature and subject to potentially large errors in parameter estimates. The limitation of this numerical model are i) mass balance errors, ii) abrupt changes in grid sizes and aquifer properties, iii) unknown aquifer parameters, and iv) limited data. Because of these reasons, a wide range of parameter values were simulated to understand the system behavior. The local bedrock ridge top was assumed as a no-flow boundary limiting regional groundwater flow to the modeled area. This consideration might have significant influence on the model mass balance.

This modeling approach is only a coarse-scale approximation of groundwater flow in alluvial aquifer and subject to many uncertainties. Despite the limitation, the numerical model shows a reasonable response of an alluvial aquifer to pumping under fluctuating stream stage. Bank storage occurred only during high stages and stream exfiltration occurred year-round in response to pumping. The width of a partial penetrating stream could be an influencing parameter while estimating stream exfiltration due to pumping. 


\section{Synthesis}

Groundwater-surface water interaction can be driven by a variety of hydrogeological, climatic, and human factors. In this research, seasonal and human influences on this process were investigated at three PWS systems along the Ohio River using water level and temperature measurements. Analytical and numerical models based on field observations were employed to characterize flow and head distributions in these discontinuous aquifers as they responded to fluctuations in river stage.

Most PWS systems along the Ohio River rely on shallow, unconfined, highly transmissive aquifers. Groundwater is their primary source of drinking water; however, scientifically-defensible information about flow directions and recharge sources lack in these systems. This hinders response to incidents of groundwater contamination that have recurred in this formerly heavily-industrial valley. This research was carried out to address this lack of information.

There were some unanticipated results. Both water level and temperature at pumping wells change abruptly and continually in response to pumping. These changes were largest for wells closest to the surface and nearest to the river. Bank storage was observed to greatly increase during high stages. Stream exfiltration was interpreted to occur year round induced by pumping and constitutes a significant portion of the water budget for a number of wells. The aquifer water level on the upstream of Hannibal Dam had higher head than the downstream suggesting lateral groundwater flow along the river.

These water level and thermal data offer a reliable field-based method for observation of groundwater-surface water exchange. Its collection is made possible only by the extensive 
development of datalogger technology in the last 25 years. Stream exfiltration is such an important source of water that it makes this PWS groundwater source even more vulnerable to contamination than it already is due to its unconfined nature. This is likely to require greater regulatory efforts for protection from contamination and, perhaps, more monitoring.

A number of research questions here remain unanswered. Source water identification was attempted by field data collection, an analytical model, and a numerical model. Each method independently confirm that groundwater and surface water co-vary seasonally, but nonetheless continuous pumping creates a nearly steady state groundwater condition. Complex boundary conditions and lack of aquifer/well data hindered creation of a reliable numerical model, relegating it to a hypothesis-testing tool. This model suggests a significantly different water budget between low and high flow. If so, does water chemistry vary at different times of a year, and if so how much? Are there important missing components in the conceptual model upon which the flow model is based? These questions will require additional data to resolve.

The thermal results were serendipitous and not in the initial proposal for this work. However, they hold promise to aid source water identification and water budget calculation for individual wells. Future work may focus on refinement of this method and of techniques to interpret its data. For example, a vertical array of sensors at different depths inside a well and more observation points between the river and pumping wells could be very useful in refining the picture and utility of heat transport.

Groundwater-surface water connectivity is difficult to observe and measure due in large part to lack of proper instrumentation in PWS systems. Nevertheless, limited data indicated the complexity of groundwater flow near pumping wells. This work shows that continuous measurements of WL and temperature can shed light on this complexity of flow. 


\section{Common Bibliography}

Anderson, M. P., W. W. Woessner, and R. J. Hunt, 2015, Applied groundwater modeling: simulation of flow and advective transport, Academic press.

Bair, E. S., A. E. Springer , and G. S. Roadcap, 1991, CAPZONE: An analytical flow model for simulating confined, leaky confined, or unconfined flow to wells with superposition of regional water levels, Columbus, Ohio, The Ohio State University.

Barlow, P. M., L. A. DeSimone, and A. F. Moench, 2000, Aquifer response to stream-stage and recharge variations. II. Convolution method and applications: Journal of Hydrology, v. 230, p. 211-229.

Barlow, P. M., and S. A. Leake, 2012, Streamflow depletion by wells understanding and managing the effects of groundwater pumping on streamflow, Reston, VA, U.S. Geological Survey, p. 84.

Bartolino, J., 2003, The Rio Grande- competing demands for a desert river, in D. A. Stonestrom, and J. Constantz, eds., Heat as a tool for studying the movement of ground water near streams, USGS.

Bendjoudi, H., B. Cheviron, R. Guerin, and A. Tabbagh, 2005, Determination of upward/downward groundwater fluxes using transient variations of soil profile temperature: test of the method with Voyons (Aube, France) experimental data: Hydrological Processes, v. 19, p. 3735-3745.

Blandford, T. N., and P. S. Huyakorn, 1988, WHPA: A Modular Semi-Analytical Model for The Delineation of Wellhead Protection Areas, USEPA.

Boutt, D. F., and B. J. Fleming, 2009, Implications of anthropogenic river stage fluctuations on mass transport in a valley fill aquifer: Water Resources Research, v. 45, p. 14.

Brunkard, J. M., E. Ailes, V. A. Roberts, V. Hill, E. D. Hilborn, G. F. Craun, A. Rajasingham, A. Kahler, L. Garrison, and L. Hicks, 2011, Surveillance for waterborne disease outbreaks associated with drinking water-United States, 2007-2008: MMWR Surveill Summ, v. 60, p. 38-68.

Brunke, M., and T. Gonser, 1997, The ecological significance of exchange processes between rivers and groundwater: Freshwater biology, v. 37, p. 1-33.

Carslaw, H. S., and J. C. Jaeger, 1959, Conduction of heat in solids: Oxford: Clarendon Press, 1959, 2nd ed., v. 1, 261 p.

Carlston, C. W., 1962, Character and history of the upper Ohio River Valley, Geological Survey Bulletin, United States Government Printing Press, Washington, p. I1-I10. 
Chen, X., and C. Xunhong, 2003, Stream water infiltration, bank storage, and storage zone changes due to stream-stage fluctuations: Journal of Hydrology, v. 280, p. 246-264.

Chen, X. H., 2003, Analysis of pumping-induced stream-aquifer interactions for gaining streams: Journal of Hydrology, v. 275, p. 1-11.

Chen, X. H., and Y. F. Yin, 2001, Streamflow depletion: Modeling of reduced baseflow and induced stream infiltration from seasonally pumped wells: Journal of the American Water Resources Association, v. 37, p. 185-195.

Cloutier, C. A., T. Buffin-Belanger, and M. Larocque, 2014, Controls of groundwater floodwave propagation in a gravelly floodplain: Journal of Hydrology, v. 511, p. 423431.

Conrad, L., and M. Beljin, 1996, Evaluation of an induced infiltration model as applied to glacial aquifer systems: Water Resources Bulletin, v. 32, p. 1209-1220.

Constantz, J., 1998, Interaction between stream temperature, streamflow, and groundwater exchanges in Alpine streams: Water Resources Research, v. 34, p. 1609-1615.

Constantz, J., 2008, Heat as a tracer to determine streambed water exchanges: Water Resources Research, v. 44.

Constantz, J., M. H. Cox, and G. W. Su, 2003, Comparison of heat and bromide as ground water tracers near streams: Ground Water, v. 41, p. 647-656.

Constantz, J., C. L. Thomas, and G. Zellweger, 1994, Influence of diurnal variations in stream temperature on streamflow loss and groundwater recharge: Water Resources Research, v. 30, p. 3253-3264.

Cooper, H. H., and M. I. Rorabaugh, 1963, Ground-water movements and bank storage due to flood stages in surface streams, Ground-water hydraulics, Washington, U.S. Geological Survey, p. 343-366.

Cross, A., and M. Schemel, 1956, Geology of the Ohio River Valley in West Virginia, in v: XXII, Geology and economic resources of the Ohio River Valley in West Virginia: West Virginia Geol. Survey, v. 131.

Desimone, L. A., and P. M. Barlow, 1998, Use of computer programs STLK1 and STWT1 for analysis of stream-aquifer hydraulic interaction, Water Resources Investigation, Marlborough, U.S. Geological Survey, p. 45.

Ferris, J. G., 1952, Cyclic fluctuations of water level as a basis for determining aquifer transmissibility, Ground-water Hydraulics, U.S. Geological Survey, p. 17. 
Grubb, H., and H. Zehner, 1973, Aquifer diffusivity of the Ohio River alluvial aquifer by floodwave response method: US Geological Survey Journal of Research: U. S. Geological Survey Journal of Research, v. 1, p. 597-601.

Haitjema, H. M., J. Wittman, V. Kelson, and N. Bauch, 1994, WhAEM: Program Documentation for The Wellhead Analytical Model., USEPA.

Hall, F. R., and A. F. Moench, 1972, Application of Convolution Equation to Stream-Aquifer Relationships: Water Resources Research, v. 8, p. 487-493.

Hantush, M. S., 1965, Wells near streams with semipervious beds: Journal of Geophysical Research, v. 70, p. 2829-2838.

Herrmann, A., K. Prilop, and D. Duncker, 2013, Hysteresis in semi-confined fractured rock groundwater-discharge relations related to runoff formation on a small basin scale: Die Bodenkultur, v. 64, p. 33-38.

Hynds, P. D., M. K. Thomas, and K. D. M. Pintar, 2014, Contamination of groundwater systems in the US and Canada by enteric pathogens, 1990-2013: a review and pooled-analysis: Plos One, v. 9, p. e93301.

Jacob, C. E., 1950, Flow of groundwater, Engineering Hydraulics: New York, John Wiley \& Sons, p. 321-386.

Jenkins, C. T., 1968, Techniques for computing rate and volume of stream depletion by wells: Ground Water, v. 6, p. 37-46.

Jung, M., T. P. Burt, and P. D. Bates, 2004, Toward a conceptual model of floodplain water table response: Water Resources Research, v. 40, p. 1-13.

Kelly, B. P., 2001, Relations among river stage, rainfall, ground-water levels, and stage at two Missouri River flood-plain wetlands, Water-Resources Investigations, U.S. Geological Survey, p. 22.

Konikow, L. F., and J. D. Bredehoeft, 1992, Ground-water models cannot be validated: Advances in water resources, v. 15, p. 75-83.

Kozar, M. D., and M. V. Mathes, 2001, Aquifer-characteristics data for West Virginia, US Department of the Interior, US Geological Survey.

Kozar, M. D., and K. J. McCoy, 2004, Geohydrology and Simulation of Ground-Water Flow in Ohio River Alluvial Aquifers near Point Pleasant, Lubeck, Parkersburg, Vienna, Moundsville, and Glendale, West Virginia, U.S. Geological Survey, p. 48. 
Kraemer, S., H. Haitjema, and V. Kelson, 2007, Working with WhAEM2000 Capture zone delineation for a city wellfield in a valley fill glacial outwash aquifer supporting wellhead protection, in USEPA, ed., Washington DC.

Lapham, W. W., 1989, Use of temperature profiles beneath streams to determine rates of vertical ground-water flow and vertical hydraulic conductivity, Dept. of the Interior, US Geological Survey; USGPO; Books and Open-File Reports Section, US Geological Survey [distributor].

Lewandowski, J., G. Lischeid, and G. Nutzmann, 2009, Drivers of water level fluctuations and hydrological exchange between groundwater and surface water at the lowland River Spree (Germany): field study and statistical analyses: Hydrological Processes, v. 23, p. 2117-2128.

Maharjan, M., and J. J. Donovan, 2016, Groundwater response to serial stream stage fluctuations in shallow unconfined alluvial aquifers along a regulated stream (West Virginia, USA): Hydrogeology Journal, v. 24, p. 2003-2015.

McCarthy, L., and M. Cabbage, 2016, Visualizing the Warmest August in 136 Years.

McDonald, M. G., and A. W. Harbaugh, 1988, A modular three-dimensional finite-differnce groundwater flow model, U.S. Geological Survey, p. 586.

McFadden, M. C., 1983, Groundwater investigation of an alluvial terrace, Redwood Creek, Humboldt County, California, using a flood-wave response model, Humboldt State University, $75 \mathrm{p}$.

Mercurio, J. W., M. S. Geljin, and B. J. Maynard, 1999, Groundwater modles and wellfield management: a case study: Environmental Engineering and Policy, v. 1, p. 155-164.

Neuman, S. P., 1972, Theory of flow in unconfined aquifers considering delayed response of water table: Water Resources Research, v. 8, p. 1031-\&.

Noorduijn, S. L., G. A. Harrington, and P. G. Cook, 2014, The representative stream length for estimating surface water-groundwater exchange using Darcy's Law: Journal of Hydrology, v. 513, p. 353-361.

Pinder, G. F., J. D. Bredehoeft, and H. H. Cooper, 1969, Determination of aquifer diffusivity from aquifer response to fluctuations in river stage: Water Resources Research, v. 5, p. $850-855$.

Pool, D. R., and J. H. Eychaner, 1995, Measurements of aquifer-storage change and specific yield using gravity surveys: Ground Water, v. 33, p. 425-432.

Prellwitz, H. S., 2004, Riverbank Geology, Conditions, and Access Reports: Pittsburgh, Carnegie Mellon University, p. 26. 
Reynolds, R. J., 1987, Diffusivity of Glacial-Outwash Aquifer by the Floodwave-Response Technique: Groundwater, v. 25, p. 290-299.

RK\&K, 2002, Marshall County PSD, a Community Public Water Supply, Source Water Assessment, Delineation, and Protection Plan, West Virginia Department of Health and Human Resources, Bureau for Public Health, Office of Environmental Health Services, Environmental Engineering Division, p. 25.

Rogers, R. L., 1990, Late Quaternary stratigraphy and geologic history of the upper Ohio River Valley, near Gallipolis Locks and Dam: M.S. thesis, West Virginia University, 161 p.

Rosenshein, J. S., 1988, Region 18, Alluvial valley, The Geology of North America: Boulder, Colo., Geological Society of America, p. 165-175.

Rowe, P., 1960, An equation for estimating transmissibility and coefficient of storage from river-level fluctuations: Journal of Geophysical Research, v. 65, p. 3419-3424.

Rötting, T. S., J. Carrera, J. Bolzicco, and J. M. Salvany, 2006, Stream-Stage Response Tests and Their Joint Interpretation with Pumping Tests: Groundwater, v. 44, p. 371-385.

Serfes, M. E., 1991, Determining the mean hydraulic gradient of ground water affected by tidal fluctuations: Ground Water, v. 29, p. 549-555.

Sheets, R. A., R. A. Darner, and B. L. Whitteberry, 2002, Lag times of bank filtration at a well field, Cincinnati, Ohio, USA: Journal of Hydrology, v. 266, p. 162-174.

Silliman, S. E., and D. F. Booth, 1993, Analysis of time-series measurements of sediment temperature for identification of gaining vs. losing portions of Juday Creek, Indiana: Journal of Hydrology, v. 146, p. 131-148.

Simard, C. M., 1989, Geologic history of the lower terraces and floodplains of the upper Ohio River Valley: M.S. thesis, West Virginia University, 161 p.

Sophocleous, M., 2002, Interactions between groundwater and surface water: the state of the science: Hydrogeology Journal, v. 10, p. 52-67.

Sophocleous, M., M. Townsend, L. Vogler, T. McClain, E. Marks, and G. Coble, 1988, Experimental studies in stream-aquifer interaction along the Arkansas River in central Kansas-Field testing and analysis: Journal of Hydrology, v. 98, p. 249-273.

Spane, F. A., and R. D. Mackley, 2011, Removal of River-Stage Fluctuations from Well Response Using Multiple Regression: Ground Water, v. 49, p. 794-807.

Springer, A. E., and E. S. Bair, 1992, Comparison of Methods Used to Delineate Capture Zones of Wells: 2. Stratified-Drift Buried-Valley Aquifer: Ground Water, v. 30, p. 908-917. 
Squillace, P. J., 1996, Observed and simulated movement of bank-storage water: Ground Water, v. 34, p. 121-134.

Stallman, R., 1965, Steady one-dimensional fluid flow in a semi-infinite porous medium with sinusoidal surface temperature: Journal of Geophysical Research, v. 70, p. 2821-2827.

Stonestrom, D. A., and J. Constantz, 2003, Heat as a tool for studying the movement of ground water near streams, US Dept. of the Interior, US Geological Survey.

Strack, O. D. L., 1994, CZAEM User's Guide, Modeling Capture Zones of Ground Water Wells Using Analytic Elements, USEPA.

Su, G. W., J. Jasperse, D. Seymour, and J. Constantz, 2004, Estimation of hydraulic conductivity in an alluvial system using temperatures: Ground Water, v. 42, p. 890.

Suzuki, S., 1960, Percolation measurements based on heat flow through soil with special reference to paddy fields: Journal of Geophysical Research, v. 65, p. 2883-2885.

Taniguchi, M., 1993, Evaluation of vertical groundwater fluxes and thermal properties of aquifers based on transient temperature-depth profiles: Water Resources Research, v. 29, p. 2021-2026.

Todd, D. K., 1980, Groundwater Hydrology: New York, John Wiley \& Sons, 535 p.

Unthank, M. D., 2013, Evaluation of the Groundwater-Flow Model for the Ohio River Alluvial Aquifer near Carrollton, Kentucky, Updated to Conditions in September 2010, Scientific Investigations Report 2013-5032, U.S. Geological Survey, p. 22.

USACE, 2003, Ohio River navigation Charts Pittsburgh, Pennsylvania to New Martinsville, West Virginia.

USEPA, 1994, Plugging and abandoning injection wells, in USEPA, ed., Chicago.

USEPA, 1997, For the national guidance on state source water assessment and protection programs.

USEPA, 2004, States making progress on source water assessments, but effectiveness still to be determined.

USEPA, 2008, Factoids: Drinking water and groundwater statistics for 2007.

Walker, R. L., 2001, Effects of pumping on ground-water flow near water-supply wells in the lower Potomac-Raritan-Magothy aquifer, Pennsauken Township, Camden County, New Jersey, Water-Resources Investigations Report, West Trenton, U. S. Geological Survey, p. 12 . 
Wallace, R. B., Y. Darama, and M. D. Annable, 1990, Stream depletion by cyclic pumping of wells: Water Resources Research, v. 26, p. 1263-1270.

Wang, H. F., and M. P. Anderson, 1980, Introduction to Groundwater Modeling, Academic press, $237 \mathrm{p}$.

Webb, S. E., 2003, Numerical analysis of source-water dynamics for stream-bounded alluvial aquifers, West Virginia University, Morgantown, WV., 119 p.

Weight, W. D., and J. L. Sonderegger, 2001, Manual of applied field hydrogeology, McGrawHill.

Welch, C., P. G. Cook, G. Harrington, and N. I. Robinson, 2013, Propagation of solutes and pressure into aquifers following river stage rise: Water Resources Research, v. 49, p. $5246-5259$.

Welch, C., G. A. Harrington, M. Leblanc, J. Batlle-Aguilar, and P. G. Cook, 2014, Relative rates of solute and pressure propagation into heterogeneous alluvial aquifers following river flow events: Journal of Hydrology, v. 511, p. 891-903.

Winter, T. C., J. W. Harvey, O. L. Franke, and W. M. Alley, 1998, Groundwater and surface water a single resource, U.S. Geological Survey, 1998, p. 87.

Zhou, Y., and W. Li, 2011, A review of regional groundwater flow modeling: Geoscience Frontiers, v. 2, p. 205-214.

Zurawski, A., 1978, Summary Appraisals of the Nation's Ground-water Resources--Tennessee Region: Ground-water Development and Management Opportunities in the Region, US Government Printing Office. 